Preliminary Correlation of Post-Erie Interstadial

Events (16,000-10,000 Radiocarbon Years Before Present),

Central and Eastern Great Lakes Region, and Hudson, Champlain, and St. Lawrence Lowlands, United States and Canada

GEOLOGICAL SURVEY PROFESSIONAL PAPER 1089

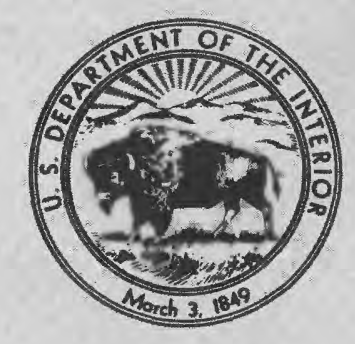


Preliminary Correlation of Post-Erie Interstadial Events (16,000-10,000 Radiocarbon Years Before Present), Central and Eastern Great Lakes Region, and Hudson, Champlain, and St. Lawrence Lowlands, United States and Canada

By DAVID S. FULLERTON

GEOLOGICAL S URVEY PROFESSIONAL PAPER 1089

A correlation of glacial and proglacial lakes, glacial tills, end moraines, and related features

from eastern Wisconsin to western Vermont and Quebec

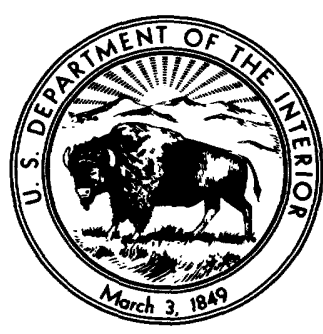




\section{UNITED STATES DEPARTMENT OF THE INTERIOR \\ CECIL D. ANDRUS, Secretary}

GEOLOGICAL SURVEY

H. William Menard, Director

Library of Congress Cataloging in Publication Data

Fullerton, David S.

Preliminary correlation of post-Erie interstadial events (16,000-10,000 radiocarbon years before present).

(Geological Survey Professional Paper 1089)

Bibliography: p. 33

1. Geology, Stratigraphic-Quaternary. 2. Stratigraphic correlation-Canada. 3. Stratigraphic correlationUnited States. 4. Radioactive dating. I. Title: Professional Paper 1089. QE696.F84 $551.7^{\prime} 9$ 78-18292

For sale by the Superintendent of Documents, U.S. Government Printing Office Washington, D.C. 20402

Stock Number 024-001-03289-9 


\section{CONTENTS}

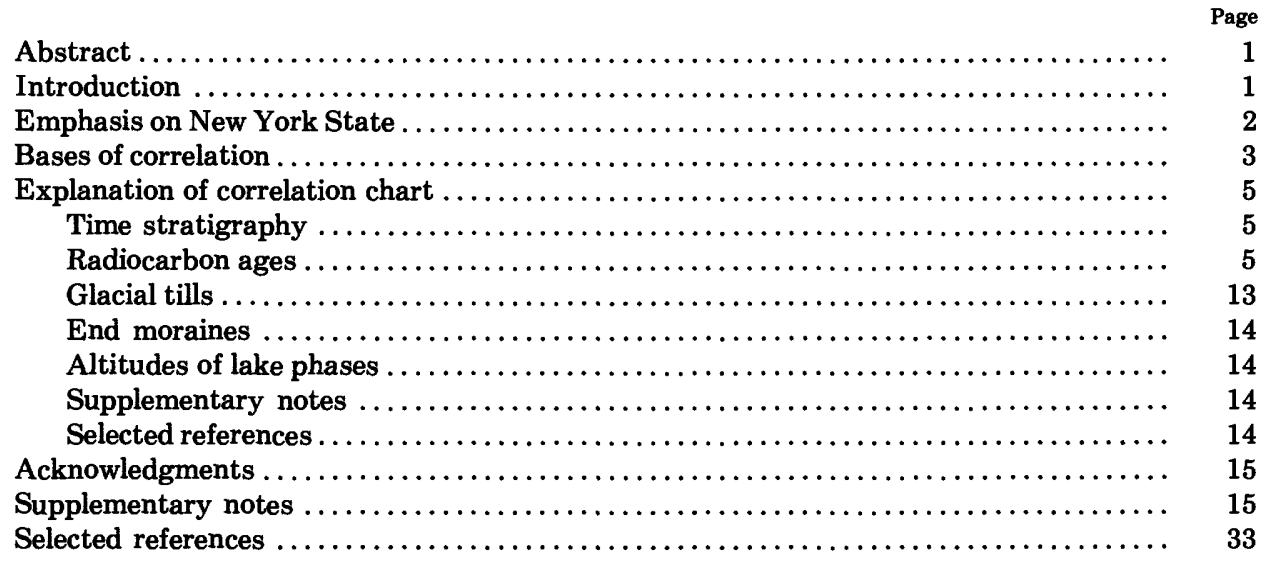

\section{ILLUSTRATIONS}

Plate 1. Preliminary correlation of post-Erie interstadial events central and eastern Great Lakes region and Hudson, Champlain,

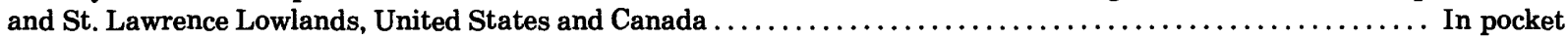

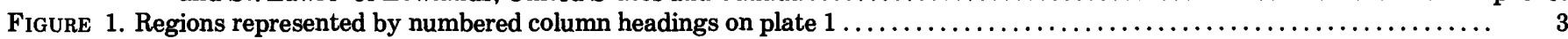

2. Map of late Wisconsinan (Woodfordian) ice-flow patterns in the central and eastern Great Lakes region .............

\section{TABLES}

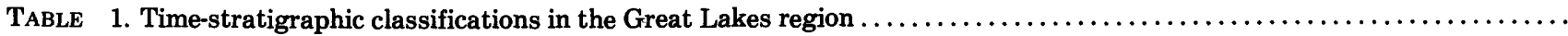
2. Selected radiocarbon ages and sources 


\section{METRIC-ENGLISH EQUIVALENTS}

[SI, International System of Units, a modernized metric system of measurement]

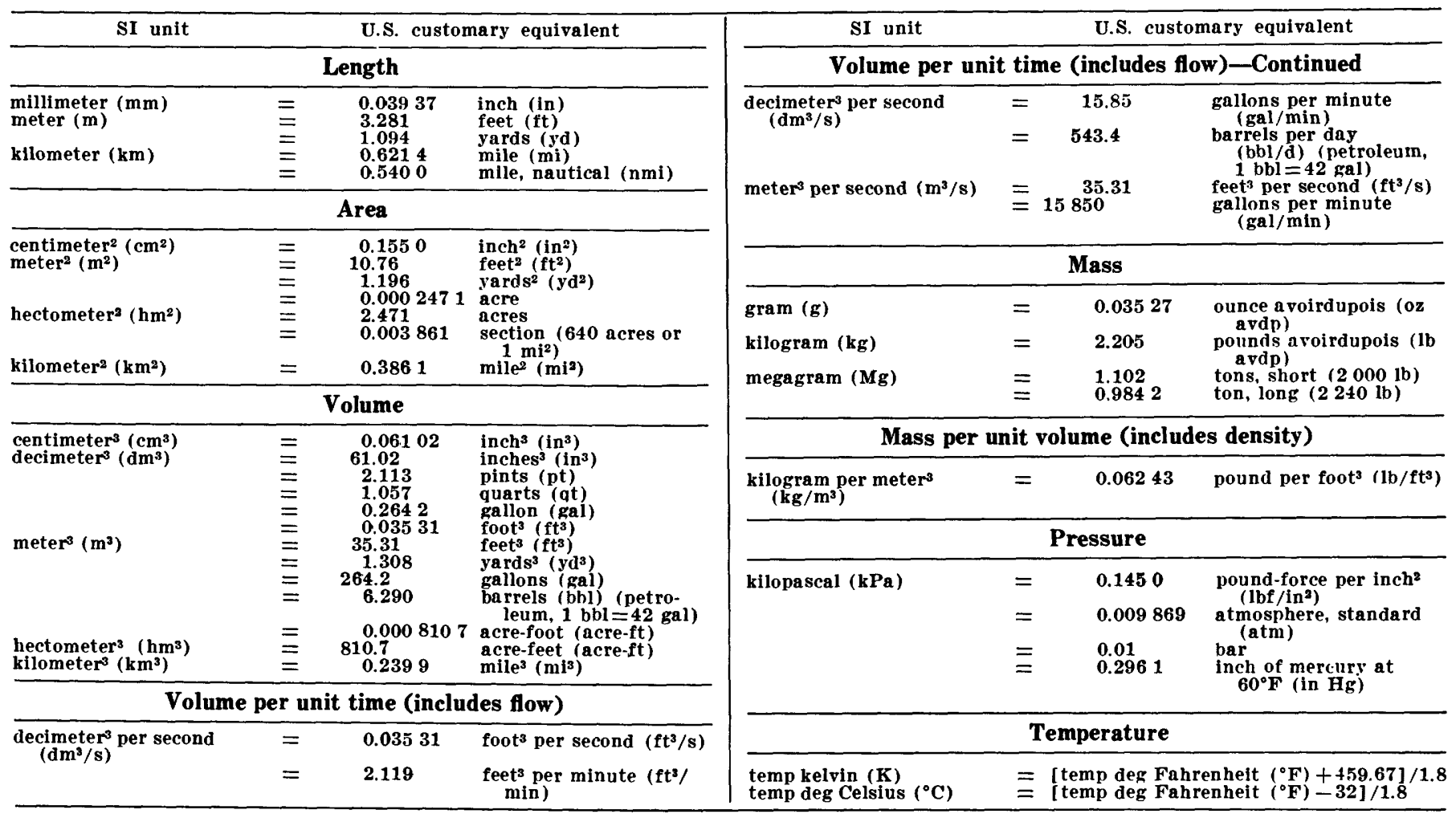




\title{
PRELIMINARY CORRELATION OF POST-ERIE INTERSTADIAL EVENTS (16,000-10,000 RADIOCARBON YEARS BEFORE PRESENT), CENTRAL AND EASTERN GREAT LAKES REGION, AND HUDSON, CHAMPLAIN, AND ST. LAWRENCE LOWLANDS, UNITED STATES AND CANADA
}

\author{
By DAVID S. FULlERTON
}

\begin{abstract}
A tentative correlation of glacial and deglacial events between approximately 16,000 and 10,000 radiocarbon years before present in the central and eastern Great Lakes region and the Hudson, Champlain, and St. Lawrence Lowlands is presented as a correlation chart. Stratigraphic, morphologic, and chronologic data from New York are integrated with similar data from parts of Wisconsin, Michigan, Illinois, Indiana, Ohio, Pennsylvania, New Jersey, Vermont, Ontario, and Quebec to provide a regional synthesis of glacial and deglacial events.

Ancestral lake phases are correlated on the basis of drainage relationships of the lake phases and continuity of strand features from one basis or lowland into another. Tills are correlated on the basis of lithostratigraphic continuity and their stratigraphic relationships to strand features and sediments of lake phases. End moraines are correlated on the basis of morphostratigraphic continuity, correlations of the tills of which they are composed, and relationships of moraines to strand features and sediments of lake phases. Radiocarbon ages that have been assigned to lake phases, advances and recessions of ice margins, and formation of end moraines are not considered as a primary basis for correlation.

Two schemes of time-stratigraphic classification are used on the chart and in the text. The classification of Dreimanis and Karrow (1972) is based on stratigraphic relationships in the Lake Huron, Lake Erie, and Lake Ontario basins and the St. Lawrence Lowland. The classification of Frye and others (1968) is based on stratigraphic relationships in Illinois and the Lake Michigan basin, and presently it cannot be extended east of Indiana and Michigan by lithostratigraphic criteria.

The correlations presented on the chart are a result of assessment of original observational data; they are not based on interpretations from published summaries and syntheses. More than 2,500 sources were consulted to obtain the observational data to construct the chart. Many of the stratigraphic and morphologic data upon which earlier syntheses of Great Lakes history were based were published more than 50 years ago, and the original sources were not referenced in the more recent summaries. Unpublished dissertations, theses, open-file reports, and manuscripts also contain a large body of very significant field data. The more than 800 selected references include many obscure but important sources of observational data that should be consulted in any attempt to reconstruct the postErie interstadial glacial and deglacial history in this region.
\end{abstract}

More than 290 radiocarbon ages that provide maximum, approximate, or minimum ages for events are included on the chart. A series of supplementary notes accompanies the chart to clarify some correlations and to focus attention on inconsistent interpretations and selected unsolved problems.

\section{INTRODUCTION}

The development of a stratigraphic scheme can have no final conclusion, because the work is never finished. It goes on indefinitely, usually in a series of jumps, slowly reaching ever-more-probable correlations $* * *$ Although parts of the structure are surely in error, little by little and perhaps at times painfully, these will be set right, and progress will continue with greater and greater refinement. (Flint, 1976, p. 407)

Chronologic and correlation schemes of glacial and deglacial events that postdate the Erie interstadial in the central and eastern Great Lakes region and in the Hudson, Champlain, and St. Lawrence Lowlands have evolved rapidly during the past 25 years. The schemes of Flint (1947, 1953, 1955, 1956, 1957), Hough (1953, 1958, 1963, 1966, 1968), Flint and Rubin (1955), and Kelley and Farrand (1967), based on earlier studies, were very generalized because of a paucity of information, limited chronologic control, and a desire for simplicity. More recent reviews and syntheses by Wayne and Zumberge (1965), Lewis (1969), Dorr and Eschman (1970), Eschman and Farrand (1970), Prest (1970), Flint (1971, 1976), Sly and Lewis (1972), Terasmae, Karrow, and Dreimanis (1972), Dreimanis and Goldthwait (1973), Farrand and Eschman (1974), and Evenson and Dreimanis (1976) refined the earlier correlations and added much new observational data and chronologic control.

On plate $1 \mathrm{I}$ attempt to integrate stratigraphic, morphologic, and chronologic data from New York into a unified working framework of correlation. Using this framework, a further attempt is made to integrate the 
history of post-Erie interstadial lake phases and icemargin fluctuations from eastern Wisconsin to eastern New York into a correlation scheme that is compatible with existing data from all of northeastern North America.

The correlations presented here, founded in part on earlier correlation schemes, are less satisfactory than the earlier schemes in many respects-they incorporate new facts and considerations that introduce uncertainties and inconsistencies. Although the scheme presented here answers some questions, it implicitly poses even more new questions. Because of its complexity and the large geographic area considered, the present scheme is more vulnerable to criticism of details than were its predecessors. I hope it will promote detailed field studies designed to expand the stratigraphic and chronologic control of correlations and refine the local and regional successions of events. Possibly no worker in the region under consideration will agree with all the correlations and age assignments that are presented here as a working model. It is hoped that those who favor interpretations presented here and those who favor alternative interpretations will be stimulated to publish new stratigraphic and chronologic data that will demonstrate conclusively the necessity for acceptance of specific correlations.

Correlations of ancestral Great Lakes phases are controversial, subjective, and tenuous. The problems involved are succinctly stated in the following quotations by J. L. Hough.

The existence of lake stages at the various levels reported is, in general, unquestioned. The sequence of occurrence of various stages within a single lake basin is a matter of interpretation, and the correlation of the sequence worked out for one basin with the sequence in another basin is a matter of further interpretation. Some of the interpretations $* * *$ must be rejected because of new evidence, and other interpretations are open to serious question because of lack of evidence. (Hough, 1953, p. 24).

Interpretation of the evidence is fairly easy and straightforward, to the extent of defining a single event, or even some series of events, within one of the lake basins; but the deciphering of the entire history of one basin, as well as of the whole region, involves the correlation of events in all of the basins. This more abstract procedure relies more heavily on subjective interpretation of fragmentary data, and it is to be expected therefore that there will be some differences of opinion among various investigators at any one time and that the history of the lakes is subject to frequent revisions as long as new evidence is being obtained. (Hough, 1963, p. 89).

It is necessary to distinguish carefully between interpretations of other workers and the data upon which the interpretations were based, particularly in the preparation of a regional synthesis. Terasmae and Dreimanis (1976, p. 52) concluded that:

When insufficient information and few data are available, it is temptingly easy to propose rather simple, quite reasonable, and apparently correct hypotheses. In these circumstances most of the existing evidence can be interpreted only in a subjective and qualified manner, and analogy is commonly used as "proof." Nearly all significant interpretations have been consistent with the evidence at hand; a matter readily verified when one makes a study of the relevant literature relating to any particular case. Because of this, one must remember that there is a substantial difference between the data that are only consistent with a proposed hypothesis and the data that compel the acceptance of a hypothesis. Unfortunately, in many recent big picture syntheses this distinction is not always made clear.

It is important, therefore, that a careful and critical evaluation be made of available evidence (relating to any particular existing hypothesis) from time to time, prior to the tentative working hypotheses becoming ingrained as authoritative and governing theories or an axiom.

Many researchers tend to rely upon authority, and too often they accept published interpretations without critical appraisal of the data upon which the interpretations are based. If an author's data from one locale are consistent with a published chronologic or correlation scheme, he commonly concludes that his new data confirm the validity of that scheme. Alternative hypotheses that also are compatible with the new data too often are not considered.

Summaries of work performed chiefly by the authors of the summaries and their coworkers generally are reliable sources of data for correlation of events in the Great Lakes region and the St. Lawrence Lowland. Publications by Willman and Frye (1970), Frye and Willman (1973), Johnson (1976), Dreimanis and Karrow (1972), Terasmae, Karrow, and Dreimanis (1972), Karrow (1974a), Terasmae and Dreimanis (1976), McDonald and Shilts (1971), Gadd, McDonald, and Shilts (1972), Gadd, LaSalle, Dionne, Shilts, and McDonald (1972), and Gadd (1976) are examples of works that accurately summarize the state of knowledge when the manuscripts were written.

Published syntheses that are merely literature reviews are not reliable sources of data for purposes of correlation. The literature surveys are merely summaries of interpretations and conclusions of other workers; the data upon which the interpretations and conclusions were based are not reviewed or evaluated. Many tenous and implausible correlations have been perpetuated and given apparent credibility as a consequence of their incorporation into "review" syntheses. Unfortunately, many workers assume that the most recent review or synthesis contains the most reliable and up-to-date information available for a particular region, and they assume that original sources of data no longer need to be consulted.

\section{EMPHASIS ON NEW YORK STATE}

Parts of New York are included in six of the nine numbered columns on the chart (pl. 1; fig.1). Emphasis is placed on New York for two reasons. First, the 
Wisconsinan history of New York and New Jersey is less well known than that in most other states and provinces under consideration. Muller (1965a), Flint (1976), and Coates (1976) outlined some of the problems involved in establishing correlations in New York. Second, eastward drainage of lakes in the Michigan, Huron, and Erie lake basins could have occurred only when the Batavia reentrant, the Syracuse channels, the Mohawk Lowland, and the central and southern Hudson Lowland in New York were free of active ice. Previous authors have inferred that eastward drainage was possible at the times indicated by their correlations in the Michigan, Huron, and Erie lake basins, but they have not presented a synthesis of morphologic, stratigraphic, and chronologic data from New York as a test of their interpretations. The pres- ent chart evolved from a preliminary correlation of lake phases, tills, and end moraines in New York (Fullerton, 1971). Consequently, the correlation of events in lake basins west of New York, proposed here, has been adjusted to comply with the inferred history of events in New York, and the correlation of events in New York has been adjusted to comply with the inferred history of events in lake basins to the west, within present limits of resolution.

\section{BASES OF CORRELATIONS}

The present correlations of ancestral lake phases are based upon continuity of strand features from one basin or lowland into another and upon drainage relationships of lake phases. Tills are correlated on the

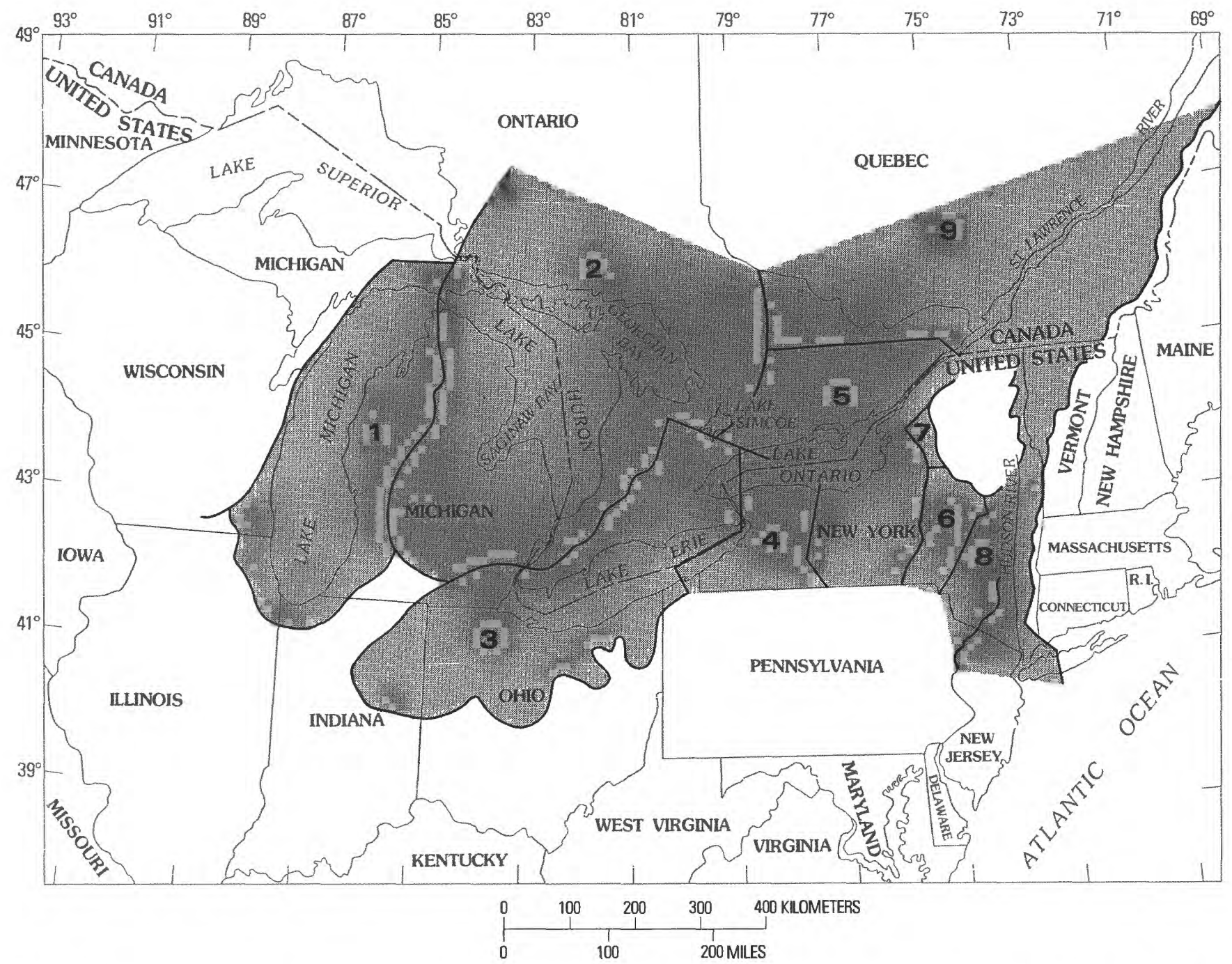

FigURE 1.-Regions represented by numbered column headings on plate 1. Some boundaries between numbered regions are arbitrarily defined in order to reduce repetition of events in different columns on the chart. Many events that are confined to a single column on the chart are recorded in parts of two or more adjacent regions shown on the map. 
basis of lithostratigraphic continuity and their stratigraphic relationships to strand features and sediments of lake phases. End moraines are correlated on the basis of morphostratigraphic continuity, correlations of the tills of which they are composed, and relationships of moraines to strand features and sediments of specific lake phases.

Radiocarbon ages that have been assigned to lake phases, to advances and recessions of ice margins, and to formation of end moraines are not considered as a primary basis for correlation. (See the section on "Radiocarbon Ages.") Interregional correlations based solely on radiocarbon ages in many instances are incompatible with morphologic and stratigraphic evidence. Radiocarbon controls of the same event or correlative events in different columns on the chart are inconsistent. Also, ages of initiation and termination of lake phases and ages of end moraines cannot be closely defined on the basis of radiocarbon controls.

Till boundaries, end-moraine configurations, lake outlets, and strand altitudes from consulted sources were plotted on base maps for evaluation. Strand altitudes were projected graphically to allow evaluation of published postglacial uplift profiles for the Michigan, Huron, Erie, and Ontario lake basins and the Hudson, Champlain, and St. Lawrence Lowlands.

Many lake phases in the Huron, Erie, and Ontario lake basins drained into other lakes by way of channels that now are abandoned. Channel configurations, terraces above channel floors, deltas at channel mouths, and beaches and bars at channel heads may permit correlation of lake phases in adjacent basins or lowlands during intervals of drainage. For example, Lake Whittlesey, in the Lake Erie basin, drained into Lake Saginaw, in the Lake Huron (Saginaw) basin, by way of the Ubly channel; Lake Saginaw drained into Lake Chicago, in the Lake Michigan basin, by way of the Grand Valley. Synchroneity of Lakes Saginaw and Whittlesey is assured because the former received drainage from the latter, both were dammed by the margin of the same ice lobe, and recession of the ice margin caused coalescence of the waters and formation of Lake Warren I. Terraces in the Grand Valley can be traced from the outlet of Lake Saginaw to the Allendale delta, indicating that Lake Saginaw drainage entered a Glenwood phase of Lake Chicago in the Lake Michigan basin (Eschman and Farrand, 1970; Farrand and Eschman, 1974). It follows that a Glenwood phase of Lake Chicago existed in the Lake Michigan basin while Lake Whittlesey existed in the Lake Erie basin. In like manner, terraces in the Grand Valley indicate that at least part of the drainage from Lake Warren I, in the Lake Erie basin, entered a Calumet phase of Lake Chicago (Eschman and Farrand, 1970; Farrand and Eschman, 1974).
Moraines or tills in neighboring basins or lowlands may be correlated on the basis of mutual relationships to lake strands or sediments. For example, the Outer Port Huron moraine in Michigan and the Wyoming moraine in Ontario were formed as a result of a major glacial readvance in the Lake Huron basin; the readvance was contemporaneous with the rise of waters in the Lake Erie basin to the Whittlesey level (Bretz, 1951a). The Paris and Norfolk (Long Point) moraines in Ontario and the Girard (Erie) moraine in Pennsylvania were formed as a result of a major glacial readvance in the Lake Ontario and eastern Lake Erie basins; the latter advance also was contemporaneous with the rise to the Whittlesey level (Karrow, 1963; Wall, 1968; Fullerton, 1971; Sly and Lewis, 1972; Terasmae and others, 1972). The "Port Huron" till in Michigan, of which the Outer Port Huron moraine is composed, the St. Joseph till in Ontario, of which the Wyoming moraine is composed, and the Wentworth Till in Ontario, of which the Paris and Norfolk moraines are composed, have a common stratigraphic relationship to strands and sediments of Lake Whittlesey and pre-Whittlesey lakes. Correlation of the tills and approximate correlation of the moraines can be inferred confidently on the basis of stratigraphic relationships of the tills to Lake Whittlesey sediments, without regard to the observed morphostratigraphic continuity of the moraines, the demonstrated lithostratigraphic equivalence of the tills, or the limited radiocarbon controls of the till and end-moraine correlations. Although the till boundaries are not everywhere represented by end moraines, the moraines can be assumed to be correlative within present limits of time resolution in the Great Lakes region.

Altitudes of lake phases in neighboring basins or lowlands may place restraints on correlations. For example, Lake Ypsilanti, in the Lake Erie basin, was too low to have drained westward (Kunkle, 1963; Wall, 1968; Dreimanis, 1969a, Sly and Lewis, 1972). The broader regional implication of eastward Great Lakes drainage by way of the Syracuse channels and the Mohawk Lowland during the Mackinaw interstadial, confirmed by stratigraphic evidence in the Mohawk Lowland (Fullerton, 1971), requires that part of the Valley Heads moraine system and perhaps all of the Tully and Cazenovia moraine systems in central New York were formed as a result of a significant Ontario lobe glacial readvance.

Because of the restraints imposed on correlations by drainage of lakes in one basin or lowland into lakes in another basin or lowland, as well as by limiting radiocarbon ages, the succession of events in each numbered column on the chart is dependent on the successions of events in adjacent columns. Lake phases in the Lake Michigan basin can be correlated with lake phases in the Lake Erie basin in a manner different 
from that on the chart only if drainage relationships, till stratigraphy, and end-moraine configurations in all the columns can be adjusted in such a manner that correlations of all other events in the columns also are still compatible with available evidence. For example, eastward drainage of lakes in the Lake Erie basin could have occurred only when the Batavia reentrant, the Syracuse channels, the Mohawk Lowland, and the central and southern Hudson Lowland were free of active ice. An alternative scheme of events in the Michigan, Huron, or Erie lake basins must be rejected if it is incompatible with the history of ice-margin fluctuations and drainage in New York.

Many correlations presented here are the same as those of other workers. In these instances either the interpretations are considered justified on the basis of observational data or the data are so inconclusive that the earlier interpretations are as plausible as alternatives. Revised interpretations presented here are based on data or arguments that lend greater support to them than to alternatives.

\section{EXPLANATION OF CORRELATION CHART}

\section{TIME STRATIGRAPHY}

Two time-stratigraphic schemes are shown on the left side of plate 1, one for the area of the Michigan lobe (fig. 2) and Illinois and one for the Huron, Erie, and Ontario lake basins and the St. Lawrence Lowland. A more detailed summary of time-stratigraphic classifications is illustrated in table 1. In principle and in practice, neither scheme is truly a time-stratigraphic classification. The scheme of Frye, Willman, Rubin, and Black (1968), based on loess stratigraphy, is most easily applied in Illinois, Wisconsin, western Indiana, and western Michigan, where physical tracing of rockstratigraphic units from the type areas is possible. The scheme of Dreimanis and Karrow (1972), based on till stratigraphy, is more easily applied in southern Ontario, southeastern Michigan, eastern Indiana, Ohio, Pennsylvania, New York, New Jersey, and Quebec. Events in the latter regions can be related to the Michigan lobe-Illinois scheme only be means of radiocarbon ages. The paucity of reliable ages that closely date events in New Jersey, New York, Pennsylvania, and Ohio, and the questionable reliability of correlations based solely on radiocarbon ages greatly limit useful application of the Michigan lobe-Illinois time-stratigraphic scheme in the latter regions. (See discussion in the section on "Radiocarbon Ages.") In this report the terminology used in relation to specific events is that most commonly used by workers in the respective regions.
In the time-stratigraphic classification scheme of Frye and Willman (1960) and Frye, Willman, Rubin, and Black (1968), all proglacial and nonglacial sediments above Woodfordian till and below the "Valders" (Two Rivers) Till at the Two Creeks type section in Wisconsin (Note 3) were deposited during the Twocreekan Substage. The lake sediments that underlie and overlie the Two Creeks buried forest are assigned to the Twocreekan Substage. All the radiocarbon ages from the buried forest therefore are minimum ages of the older boundary and maximum ages of the younger boundary of the substage. Frye and Willman (1960) and Frye, Willman, Rubin, and Black (1968) placed the lower boundary of the Twocreekan Substage at 12,500 B.P. (radiocarbon years before present) and the upper boundary at 11,000 B.P. (table 1). Evenson and others (1976, fig. 2) placed the lower boundary at 12,300 B.P. and the upper boundary at 11,850 B.P. In the time-stratigraphic scheme of Dreimanis and Karrow (1972), elaborated by Evenson and Dreimanis (1976), the boundary between the Port Huron stadial and the Two Creeks interstadial of their Late Wisconsinan Substage was placed at 12,500 B.P. and the boundary between the Two Creeks interstadial and the Valders stadial was placed at 11,850 B.P. (table 1).

On the basis of the estimated radiocarbon ages of events on the correlation chart (pl. 1), it seems likely that initial deposition of lake sediments on Woodfordian till at the Two Creeks type section occurred no earlier than 12,400 B.P., and perhaps later than 12,300 B.P. Deposition of Two Rivers Till on the lake sediments that overlie the buried forest probably occurred no later than 11,500 B.P. Consequently, the WoodfordianTwocreekan and Twocreekan-Valderan Substage time boundaries of Frye, Willman, Rubin, and Black (1968) are shown as solid horizontal lines on the chart, and alternative time boundaries based on correlations on the chart are shown as dashed diagonal lines. Accordingly, the Port Huron stadial-Two Creeks interstadial and Two Creeks interstadial-Valders stadial time boundaries of Evenson and Dreimanis (1976) are shown as solid horizontal lines and alternative time boundaries are shown as dashed diagonal lines.

\section{RADIOCARBON AGES}

The radiocarbon ages on the chart (pl. 1) and in table 2 are from terrestrial, freshwater, and marine materials. Some of the ages have been inferred by other authors to be incorrect on geochemical, stratigraphic, or other grounds. Other ages have been discredited in the literature because they are incompatible with interpretations of the authors, rather than because of cited geochemical or stratigraphic evidence. 


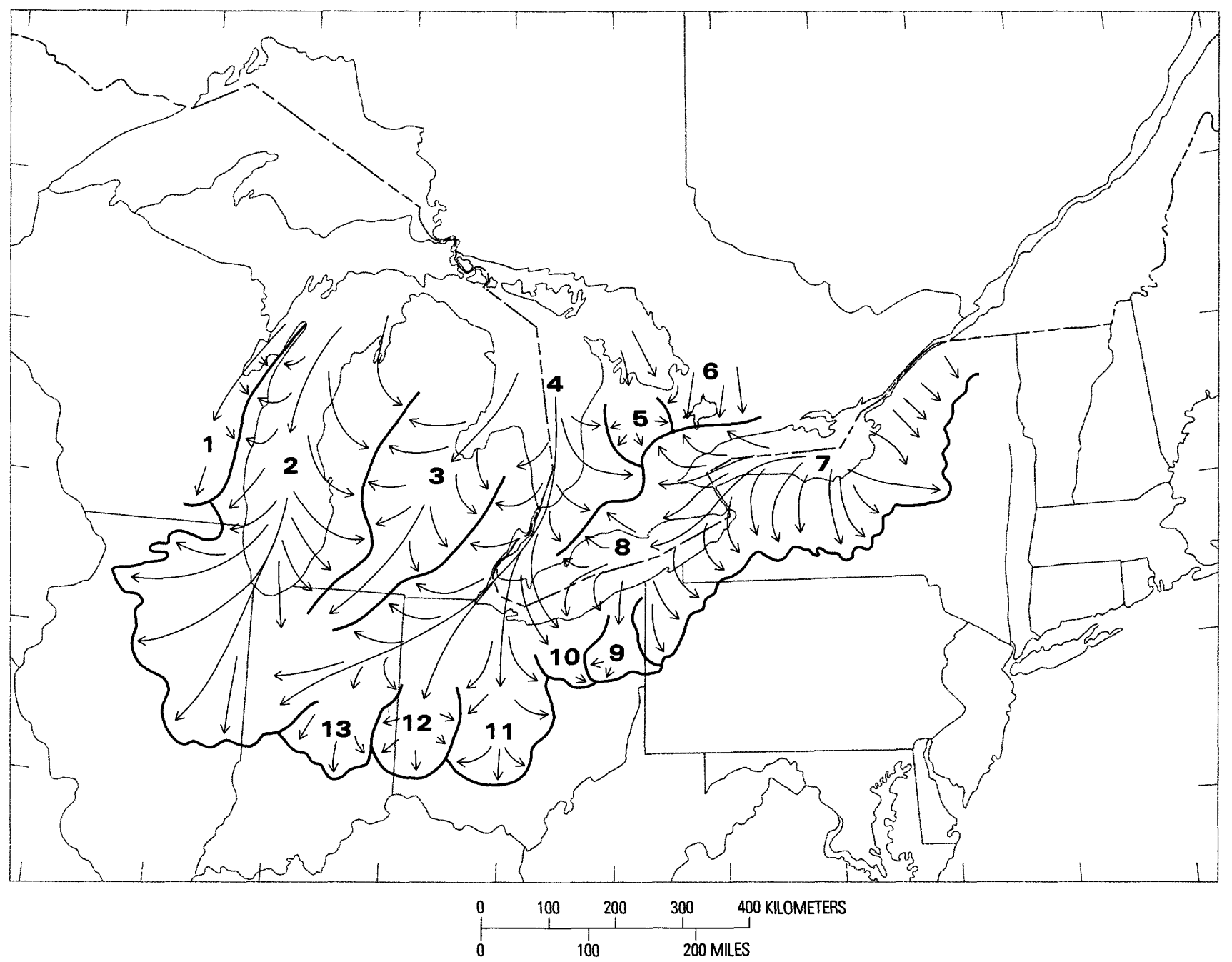

Figure 2.-Map of late Wisconsinan (Woodfordian) ice-flow patterns in the central and eastern Great Lakes region. Paths of ice movement and the locations of sutures between ice lobes changed through time, and deposits of adjacent ice lobes locally overlap one another in vertical succession. Arrows indicate very generalized ice flow paths.

1 Green Bay lobe

2 Michigan lobe

3 Saginaw sublobe

4 Huron lobe
5 Georgian Bay sublobe

6 Lake Simcoe sublobe

7 Ontario lobe
8 Erie lobe

9 Grand River sublobe

10 Killbuck sublobe
11 Scioto sublobe 12 Miami sublobe 13 East White sublobe
Marl ages commonly are too old relative to peat and wood ages, and the reliability of most bone ages is uncertain. Marine-shell ages may be too old relative to peat and wood ages, in some instances (Note 38). Basal sediments in bogs appear to be too old in some instances and too young in others. In still other instances bog-bottom ages appear to be reliable, but the basal organic sediment is $1,000-3,000$ years younger than the underlying glacial or postglacial sediments. Consequently, nearly all the ages on the chart that are from basal organic sediments in bogs are considered to be minimum ages of glacial or deglacial events, and there is no reason to assume that any of them closely limit the ages of the underlying sediments. Table 2 lists selected references for the radiocarbon ages on the chart. These sources should be consulted to evaluate the stratigraphic significance and reliability of the ages.

All the radiocarbon ages on plate 1 are included in table 2 and all ages in the table are on the chart. Many of the ages shown on plate 1 and in table 2 are not discussed under "Supplementary Notes," however.

The radiocarbon ages on the chart and in table 2 were calculated on the basis of a Libby half-life value of 
TABLE 1.-Time-stratigraphic classifications in the Great Lakes region

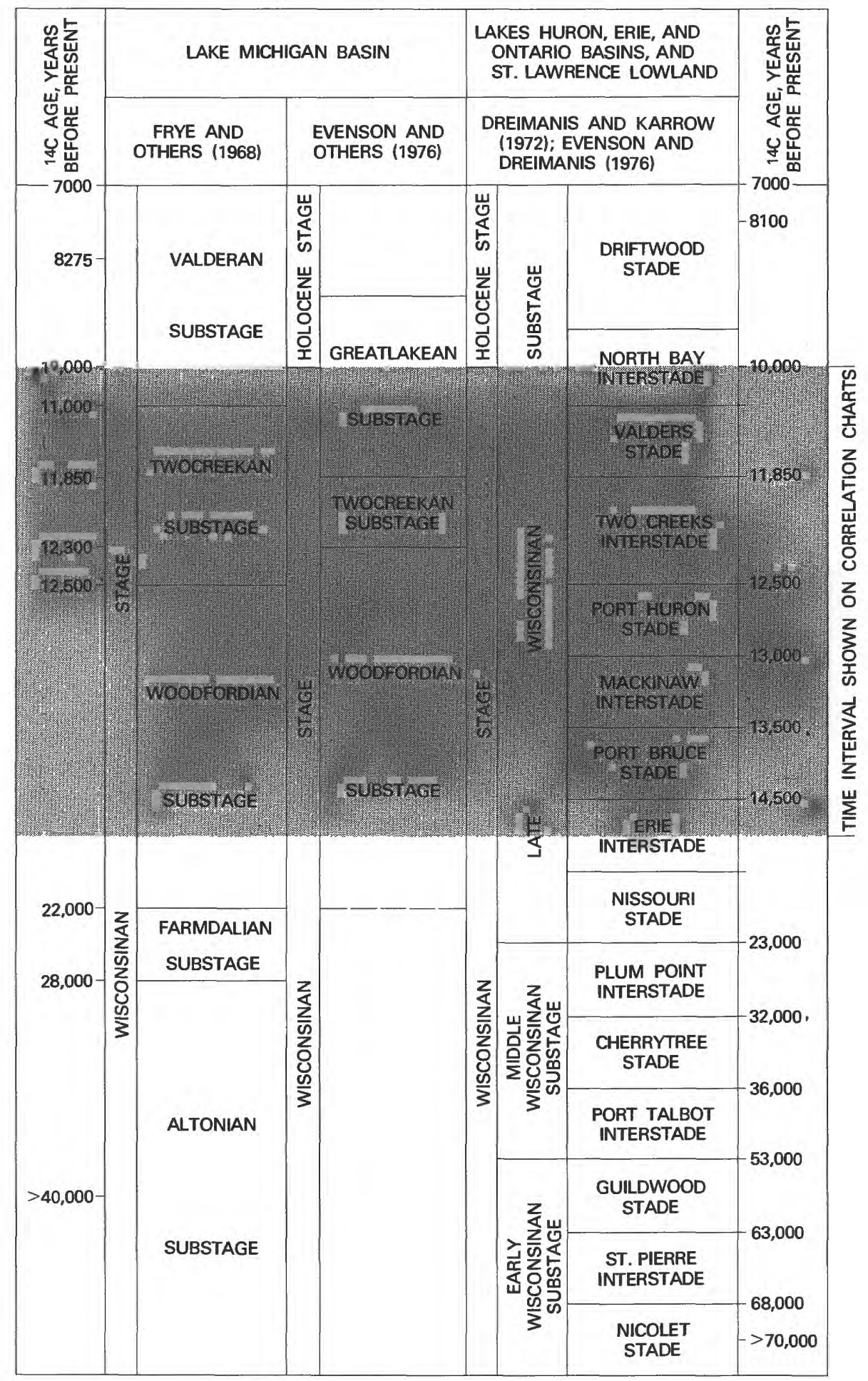

$5,570 \pm 30$ years, with A.D. 1950 as the reference year. They must be multiplied by a factor of 1.03 to adjust them to the currently accepted Godwin half-life value of $5,730 \pm 40$ years. All the ages are beyond the range of dendrochronologic calibration. The errors assigned to most measurements are \pm one-sigma standard deviations; some are \pm two-sigma deviations. In most instances the uncertainty assigned to measured ages 
TABLE 2.-Selected radiocarbon ages and sources, central and eastern Great Lakes region and Hudson, Champlain, and St. Lawrence Lowlands, United States and Canada

\begin{tabular}{lc}
\hline \multicolumn{1}{c}{ Lab No. } & Age \\
\hline A-79-A & $12,150 \pm 400$ \\
A-79-B & $12,000 \pm 400$ \\
C-308 & $10,877 \pm 740$ \\
& \\
& \\
C-365 & $11,437 \pm 770$ \\
C-366 & $11,097 \pm 600$ \\
C-536 & $12,168 \pm 1,500$ \\
C-537 & $11,442 \pm 640$ \\
C-801 & $10,661 \pm 460$ \\
& $11,284 \pm 600$ \\
DAL-4 & $14,400 \pm 430$ \\
DAL-45 & $11,360 \pm 405$ \\
& $11,600 \pm 250$ \\
DAL-47 & $13,520 \pm 270$ \\
DAL-51 & $16,650 \pm 900$ \\
DAL-65 & $13,300 \pm 310$ \\
DAL-130 & $11,255 \pm 230$ \\
DAL-131 & $12,610 \pm 400$ \\
DAL-205 & $11,790 \pm 770$ \\
& $11,920 \pm 770$ \\
DAL-1118 & $17,190 \pm 400$ \\
Gif-400 & $10,060 \pm 350$ \\
Gif-401 & $11,000 \pm 350$ \\
&
\end{tabular}

Gif-424 $\quad 10,250 \pm 350$

Gif-2106 $\quad 10,300 \pm 185$

GrN-1696 $10,450 \pm 180$

GrN-1697

GrN-2031

GrN-2032

GrN-2034

GrN-2035

GSC-61

GSC-63

GSC-70 $\quad 10,600 \pm 170$

GSC-90 $10,870 \pm 130$

GSC-102 $12,720 \pm 170$
$10,540 \pm 210$
$11,410 \pm 150$

$11,490 \pm 110$

$10,870 \pm 105$

$10,450 \pm 80$

$10,590 \pm 100$

$10,330 \pm 100$

$10,340 \pm 130$
Shutler and Damon (1959); Black and Rubin (1968). Do.

Arnold and Libby (1951); Libby (1955); Thwaites and Bertrand (1957); Hough (1958); Black and Rubin (1968).

Do.

Do.

Do.

Do.

Libby (1954, 1955); Hough (1958). Do.

Ogden and Hart (1976).

Do.

Do.

Do.

Do.

Do.

Ogden and Hart (1977).

Do.

Do.

Do.

Do.

LaSalle and Rondot (1967).

LaSalle (1966); Mott (1968); Delibrias, Guillier, and Labeyrie (1969).

LaSalle and Rondot (1967); Delibrias, Guillier, and Labeyrie (1969); LaSalle and Elson (1975).

Gangloff (1974); Delibrias, Guillier, and Labeyrie (1974).

de Vries and Barendsen (1958); Elson (1962); corrected in LaSalle (1966) and Mott (1968).

Do.

Do.

Do.

Do.

Do.

Elson (1969b).

Dyck and Fyles (1963); Gadd (1964). Do.

Dyck and Fyles (1963); Gadd (1964, 1971); Gadd, LaSalle, Dionne, Shilts, and McDonald (1972).

Dyck and Fyles (1963); Gadd (1971).

Dyck and Fyles (1963); Mott (1968); Gadd (1971).

Lee (1963b); Dyck and Fyles (1963); Gadd (1964, 1971); Gadd, McDonald, and Shilts (1972); Gadd, LaSalle, Dionne, Shilts, and McDonald (1972).
TABLE 2.-Selected radiocarbon ages and sources-Continued

\begin{tabular}{ccc}
\hline Lab No. & Age & \multicolumn{2}{c}{ Sources } \\
\hline GSC-119 & $10,460 \pm 160$ & Dyck and Fyles (1964); Mot
\end{tabular}
(1968).

$10,740 \pm 170 \quad$ Do

GSC-187 $\quad 11,410 \pm 150$

Gadd (1964); Dyck, Fyles, and Blake (1965); Gadd, McDonald, and Shilts (1972).

GSC-211 11,860 170 Dreimanis (1964a); Dyck, Lowdon, Fyles, and Blake (1966); Lewis, Anderson, and Berti (1966).

GSC-264 10,040 $1150 \quad$ Dyck, Lowdon, Fyles, and Blake (1966).

GSC-270 $10,390 \pm 160$

GSC-312 $12,640 \pm 190$ Do.

Gadd (1964); Dyck, Lowdon, Fyles, and Blake (1966); McDonald and Shilts (1971); Gadd, McDonald, and Shilts (1972); Gadd, LaSalle, Dionne, Shilts, and McDonald (1972).

GSC-314 10,050 $1390 \quad$ Dyck, Lowdon, Fyles, and Blake (1966).

GSC-330 10,200 \pm 180 Lewis, Anderson, and Berti (1966); Lowdon, Fyles, and Blake (1967); Calkin (1970). Do.

GSC-382 $11,300 \pm 160$

GSC-419 $12,570 \pm 220$

Terasmae and LaSalle (1968); Lowdon and Blake (1968); McDonald and Shilts (1971); Gadd, McDonald, and Shilts (1972); Gadd, LaSalle, Dionne, Shilts, and McDonald (1972).

GSC-420 11,020 $330 \quad$ Lowdon, Fyles, and Blake (1967); McDonald (1968b); Gadd, McDonald, and Shilts (1972).

GSC-454 10,420 $\pm 150 \quad$ Dyck, Lowdon, Fyles, and Blake (1966); Mott (1968).

GSC-475 11,530 $160 \quad$ Lowdon, Fyles, and Blake (1967); McDonald (1968b); Gadd, McDonald, and Shilts (1972).

GSC-475-2 11,300 $\pm 170 \quad$ McDonald (1968b); Lowdon and Blake (1970); McDonald and Shilts (1971); Gadd, McDonald, and Shilts (1972).

GSC-482 10,880 260 Terasmae and LaSalle (1968); Lowdon and Blake (1968).

GSC-505 11,880 $180 \quad$ Lowdon, Fyles, and Blake (1967); McDonald (1968b); Gadd, McDonald, and Shilts (1972).

GSC-570 $\quad 10,800 \pm 150$

GSC-587 $\quad 10,620 \pm 200$

GSC-588 $\quad 10,880 \pm 160$

GSC-611 $11,380 \pm 170$

GSC-620 $\quad 12,190 \pm 230$

GSC-623 $\quad 10,720 \pm 150$

GSC-625 $11,350 \pm 260$

$11,760 \pm 310$

GSC-626

GSC-649
$11,180 \pm 180$
Mott (1968); Lowdon and Blake (1970). Do. Do. Blake (1968).

Lowdon and Blake (1968); Terasmae, Karrow, and Dreimanis (1972).

Lowdon, Fyles, and Blake (1967); Mott (1968).

Lowdon and Blake (1968).

Do.

Do.
Dreimanis (1968b); Lowdon and 
TABLE 2.-Selected radiocarbon ages and sources-Continued

\begin{tabular}{|c|c|}
\hline Lab No. & Age \\
\hline GSC-679 & $11,020 \pm 170$ \\
\hline GSC-762 & $11,100 \pm 270$ \\
\hline GSC-765 & $10,500 \pm 180$ \\
\hline GSC-842 & $11,600 \pm 150$ \\
\hline GSC-890 & $10,700 \pm 160$ \\
\hline GSC-936 & $12,000 \pm 230$ \\
\hline GSC-982 & $11,300 \pm 180$ \\
\hline GSC-1013 & $11,800 \pm 210$ \\
\hline GSC-1096 & $12,800 \pm 1,23$ \\
\hline GSC-1104 & $12,000 \pm 160$ \\
\hline GSC-1108 & $10,150 \pm 190$ \\
\hline GSC-1111 & $10,200 \pm 150$ \\
\hline GSC-1126 & $10,500 \pm 150$ \\
\hline GSC-1127 & $10,600 \pm 160$ \\
\hline GSC- 1151 & $13,900 \pm 210$ \\
\hline GSC-1156 & $12,500 \pm 800$ \\
\hline GSC-1232 & $11,100 \pm 160$ \\
\hline GSC- 1235 & $11,600 \pm 160$ \\
\hline GSC-1248 & $11,200 \pm 200$ \\
\hline GSC-1275 & $10,100 \pm 240$ \\
\hline GSC-1289 & $11,000 \pm 240$ \\
\hline GSC-1294 & $11,200 \pm 160$ \\
\hline GSC-1295 & $11,200 \pm 160$ \\
\hline
\end{tabular}

GSC-1339

$14,900 \pm 220$

GSC-1344

$13,000 \pm 290$

GSC-1353

$10,700 \pm 310$

GSC-1355

GSC-1357

GSC-1363

Sources

$10,900 \pm 330$

$11,800 \pm 400$

$$
\begin{aligned}
& \text { Do. } \\
& \text { Do. } \\
& \text { Do. }
\end{aligned}
$$

Henderson (1969b); Lowdon and Blake (1970); Richard (1974, 1975b).

Lowdon, Robertson, and Blake (1971).

McDonald (1968b); Lowdon and Blake (1970); McDonald and Shilts (1971); Gadd, McDonald, and Shilts (1972).

Lowdon and Blake (1970); Richard (1975b).

Henderson (1969b); Lowdon and Blake (1970); Gadd, McDonald, and Shilts (1972).

Lowdon and Blake (1973).

Gadd, LaSalle, Dionne, Shilts, and McDonald (1972).

Lewis (1970); Lowdon, Robertson, and Blake (1971).

Karrow, Anderson, Clarke, Delorme, and Sreenivasa (1975). Do.

Do.

Lowdon and Blake (1973).

Cowan, Karrow, Cooper, and Morgan (1975).

LaSalle, Hardy, and Poulin (1972); Gadd, McDonald, and Shilts (1972); Gadd, LaSalle, Dionne, Shilts, and McDonald (1972); LaSalle and Elson (1975); Lowdon and Blake (1976).

Do.

Shilts (1969, 1970); Gadd, McDonald, and Shilts (1972).

Harrison (1972); Lowdon and Blake (1975).

Shilts (1969, 1970); Gadd, McDonald, and Shilts (1972). Do.

LaSalle, Hardy, and Poulin (1972); Gadd, LaSalle, Dionne, Shilts, and McDonald (1972); LaSalle and Elson (1975); Lowdon and Blake (1976).

Shilts (1969, 1970); Gadd, McDonald, and Shilts (1972).

LaSalle (1966); Gadd, McDonald, and Shilts (1972); Gadd, LaSalle, Dionne, Shilts, and McDonald (1972); Lowdon and Blake (1973, 1975).

Gadd, McDonald, and Shilts (1972).

Lowdon and Blake (1973). Do.

Harrison (1972).
TABLE 2.-Selected radiocarbon ages and sources-Continued

Lab No. Age Sources

GSC-1366 $10,600 \pm 150$

Karrow, Anderson, Clarke, Delorme, and Sreenivasa (1975); Lowdon and Blake (1976). Do.

GSC-1374 $11,200 \pm 170$

GSC-1404 $12,700 \pm 280$

GSC-1405 $\quad 10,000 \pm 230$

GSC-1429 $11,400 \pm 280$

Gadd, McDonald, and Shilts (1972).

Lowdon and Blake (1973).

Harrison (1972); Lowdon and Blake (1973).

$\begin{array}{ll} & 11,500 \pm 180 \\ \text { GSC-1444 } & 10,100 \pm 150\end{array}$

Lowdon and Blake (1973).

GSC-1451 $\quad 10,000 \pm 150$

Lowdon and Blake (1973).

add, McDonald, and Shilts (1972); Gadd, LaSalle, Dionne, Shilts, and McDonald (1972); Lowdon and Blake (1975); Ochietti (1976).

Gadd, McDonald, and Shilts (1972); Gadd, LaSalle, Dionne, Shilts, and McDonald (1972).

GSC-1476 11,200 \pm 170 Gadd, LaSalle, Dionne, Shilts, and McDonald (1972); LaSalle and Elson (1975).

GSC-1526 $11,600 \pm 630$ Gadd, McDonald, and Shilts (1972); Gadd, LaSalle, Dionne, Shilts, and McDonald (1972); LaSalle and Elson (1975); Occhietti (1976); age corrected in Lowdon and Blake (1975).

GSC-1533 $\quad 12,400 \pm 160$

Gadd, LaSalle, Dionne, Shilts, and McDonald (1972); Lowdon and Blake (1973); LaSalle and Elson (1975); Richard and Poulin (1976).

GSC-1553 $\quad 10,000 \pm 320$

Lowdon and Blake (1973, 1976); Richard (1975b).

GSC-1612 $11,500 \pm 150$

GSC-1644 $10,300 \pm 200$

GSC-1646

GSC-1664

GSC-1672

GSC-1684

GSC-1700

GSC-1715

GSC-1729

GSC-1739

GSC-1740

GSC-1772

GSC-1803

GSC- 1805

GSC-1859

GSC-1968
GSC-2045

GSC-2090
$12,200 \pm 160$

$11,100 \pm 160$

$11,200 \pm 160$

$11,900 \pm 160$

$12,400 \pm 170$

$11,300 \pm 140$

$12,800 \pm 220$

$10,200 \pm 90$

Lowdon and Blake (1975).

Karrow, Anderson, Clarke, Delorme, and Sreenivasa (1975); Lowdon and Blake (1976).

Lowdon and Blake (1973); Richard $(1974,1975 b)$.

Richard (1975a); Lowdon and Blake (1975).

Lowdon and Blake (1973); Richard (1975b).

Lowdon and Blake (1973).

Occhietti (1976).

Occhietti (1976). Do.

Karrow, Anderson, Clarke, Delorme, and Sreenivasa (1975); Lowdon and Blake (1975).

Lowdon and Blake (1973); Richard (1974, 1975b).

Lowdon and Blake (1975). Do.

Richard (1974, 1975b); Gadd (1976).

Gadd (1976); Lowdon and Blake (1976).

$11,100 \pm 90$

$10,600 \pm 160$
Occhietti (1976).

Do.
Saarnisto (1974). 
TABLE 2.-Selected radiocarbon ages and sources-Continued

\begin{tabular}{lc}
\hline \multicolumn{1}{c}{ Lab No. } & Age \\
\hline GSC-2101 & $10,300 \pm 100$ \\
GSC-2108 & $11,200 \pm 100$ \\
GSC-2150 & $10,200 \pm 90$ \\
GSC-2151 & $12,700 \pm 100$ \\
& \\
& \\
& $12,800 \pm 100$ \\
GSC-2213 & $13,100 \pm 110$ \\
& \\
GSC-2312 & $10,900 \pm 100$ \\
& \\
GSC-2338 & $11,900 \pm 120$ \\
& \\
GSC-2366 & $11,800 \pm 150$ \\
Gx-205 & $10,415 \pm 145$ \\
Gx-206 & $10,930 \pm 150$ \\
Hel-400 & $10,650 \pm 265$ \\
I(GSC)-11 & $10,150 \pm 450$
\end{tabular}

I(GSC)-29 $\quad 11,950 \pm 350$

$1-491 \quad 10,300 \pm 250$

I-838 $12,100 \pm 400$

I-1223 $\quad 10,200 \pm 500$

I-2917 $\quad 11,200 \pm 170$

I-3175 $12,900 \pm 200$

I-3199 $\quad 12,400 \pm 200$

I-3290 $\quad 11,800 \pm 730$

I-3647 $11,230 \pm 170$

I-3665 $12,730 \pm 220$

I-3785 $10,000 \pm 160$

I-4016 $\quad 10,950 \pm 150$

I-4040 $12,600 \pm 170$

I-4041 $11,080 \pm 160$

I-4043 $13,800 \pm 250$

I-4137 $12,530 \pm 370$

I-4216 $\quad 14,900 \pm 450$

I-4288 $10,550 \pm 220$

I-4652 $15,950 \pm 850$

I-4899 $\quad 13,770 \pm 210$

I-4986

I-5080

I-5137
$13,150 \pm 200$

$11,050 \pm 160$

$10,460 \pm 150$
Do.

Richard (1975b).

Occhietti (1976).

(S. H. Richard, Geological Survey Canada, per V. K. Prest, written commun., 1976). Do.

Gravenor and Stupavsky (1976); Lowdon and Blake (1976).

Cronin (1976); Lowdon and Blake (1976).

T. C. Cronin (written commun., 1976).

$$
\text { Do. }
$$

Krueger and Weeks (1966). Do.

Saarnisto (1974).

Karrow, Clarke, and Terasmae (1961); Walton, Trautman, and Friend (1961); Karrow (1963); Lewis, Anderson, and Berti (1966).

Walton, Trautman, and Friend (1961); Karrow (1963).

Parry (1963); Parry and MacPherson (1964); Hillaire-Marcel (1974a).

Buckley, Trautman, and Willis (1968); Calkin (1970).

Terasmae and Mirynech (1964); Dyck, Lowdon, Fyles, and Blake (1966).

Ogden and Hay (1973).

Calkin (1970).

Connally and Sirkin $(1969,1971)$.

Miller (1973).

Wagner (1969); Buckley and Willis (1970).

Calkin and McAndrews (1969); Calkin (1970); Buckley (1976).

Funk, Fisher, and Reilly (1970).

Funk, Fisher, and Reilly (1970); Buckley and Willis (1970).

Sly and Lewis (1972). Do.

Calkin (1970).

Funk, Walters, Ehlers, Guilday, and Connally (1970); Funk, Fisher, and Reilly (1970); Buckley and Willis (1972).

Calkin (1970).

Cowan, Karrow, Cooper and Morgan (1975). Do.

Burgis (1970); Buckley and Willis (1972); Farrand and Eschman (1974).

Connally and Sirkin (1971).

Buckley and Willis (1972).

Stone and Thompson (1971).
TABLE 2.-Selected radiocarbon ages and sources-Continued

\begin{tabular}{|c|c|c|}
\hline Lab No. & Age & Sources \\
\hline $\mathrm{I}-5200$ & $10,280 \pm 270$ & Weiss (1974). \\
\hline I-5663 & $12,270 \pm 180$ & Newman and Pike (1975). \\
\hline I-8022 & $12,610 \pm 200$ & Buckley (1976). \\
\hline ISGS-72 & $14,290 \pm 130$ & Totten (1973); Coleman (1973). \\
\hline ISGS-75 & $12,500 \pm 120$ & Coleman (1973). \\
\hline ISGS-76 & $12,020 \pm 110$ & Do. \\
\hline ISGS-120 & $11,740 \pm 90$ & Coleman (1974). \\
\hline ISGS-226 & $11,110 \pm 220$ & Coleman and Liu (1975). \\
\hline ISGS-348 & $10,050 \pm$ & Totten (1976). \\
\hline IU-20 & $10,150 \pm 250$ & Wayne (1968). \\
\hline IU-62 & $12,400 \pm 300$ & Schneider and Reshkin (1970). \\
\hline $\mathbf{L}-231$ & $10,890 \pm 200$ & $\begin{array}{l}\text { Broecker and Kulp (1957); Min- } \\
\text { ard and Rhodehamel (1969). }\end{array}$ \\
\hline L-604-A & $10,700 \pm 200$ & $\begin{array}{l}\text { Olson and Broecker (1961); Mott } \\
\text { (1968). }\end{array}$ \\
\hline L-604-B & $10,550 \pm 200$ & Do. \\
\hline L-604-C & $10,600 \pm 200$ & $\begin{array}{l}\text { Dyck and Fyles (1962); Mott } \\
\text { (1968). }\end{array}$ \\
\hline L-604-D & $10,200 \pm 200$ & Do. \\
\hline $\mathrm{L}-606-\mathrm{A}$ & $11,950 \pm 200$ & Newman and Pike (1975). \\
\hline L-607-A & $11,850 \pm 100$ & $\begin{array}{l}\text { Broecker and Farrand (1963); } \\
\text { Black and Rubin (1968). }\end{array}$ \\
\hline L-609 & $12,000 \pm 200$ & $\begin{array}{l}\text { Thurber, Broecker, and Kauf- } \\
\text { man (1967). }\end{array}$ \\
\hline L-639-B & $11,320 \pm 200$ & $\begin{array}{l}\text { Gadd (1964); Mott (1968); Rich- } \\
\text { ard (1975b). }\end{array}$ \\
\hline $\mathrm{L}-639-\mathrm{C}$ & $11,790 \pm 100$ & $\begin{array}{l}\text { Broecker and Farrand (1963); } \\
\text { Black and Rubin (1968). }\end{array}$ \\
\hline & $11,890 \pm 100$ & Do. \\
\hline L-1064 & $12,800 \pm 400$ & $\begin{array}{l}\text { Farrand, Zahner, and Benning- } \\
\text { hoff (1969). } \\
\text { Do. }\end{array}$ \\
\hline L-1141 & $12,500 \pm 600$ & $\begin{array}{l}\text { Newman, Thurber, Zeiss, Ro- } \\
\text { kach, and Musich (1969). }\end{array}$ \\
\hline L-1157-A & $12,850 \pm 250$ & Connally and Sirkin (1970). \\
\hline M-139 & $12,630 \pm 1,000$ & $\begin{array}{l}\text { Crane and Griffin (1958); Wayne } \\
\text { (1963). }\end{array}$ \\
\hline M-223 & $11,450 \pm 600$ & Crane (1956). \\
\hline M-224 & $11,450 \pm 600$ & Do. \\
\hline M-288-A & $11,200 \pm 600$ & $\begin{array}{l}\text { Zumberge and Potzger (1956); } \\
\text { Crane (1956); Hough (1958); } \\
\text { Broecker and Farrand (1963). }\end{array}$ \\
\hline M-300 & $12,336 \pm 700$ & Crane and Griffin (1958). \\
\hline M-342 & $10,700 \pm 600$ & $\begin{array}{l}\text { Crane (1956); Thwaites and Ber- } \\
\text { trand (1957); Hough (1958); } \\
\text { Black and Rubin (1968). }\end{array}$ \\
\hline M-343 & $10,400 \pm 600$ & Do. \\
\hline M-350 & $12,600 \pm 600$ & $\begin{array}{l}\text { Crane (1956); Goldthwait (1958); } \\
\text { Wayne (1963). }\end{array}$ \\
\hline M-507 & $12,200 \pm 700$ & Crane and Griffin (1958). \\
\hline M-639 & $13,200 \pm 600$ & $\begin{array}{l}\text { Crane and Griffin (1959); Ben- } \\
\text { ninghoff and Hibbard (1961). }\end{array}$ \\
\hline$M-1102$ & $12,660 \pm 1,000$ & Crane and Griffin (1962). \\
\hline M-1254 & $10,700 \pm 400$ & $\begin{array}{l}\text { Oltz and Kapp (1963); Crane and } \\
\text { Griffin (1965). }\end{array}$ \\
\hline M-1361 & $11,400 \pm 400$ & Crane and Griffin (1966). \\
\hline $\mathrm{M}-1402$ & $11,100 \pm 400$ & $\begin{array}{l}\text { Crane and Griffin (1964); Sem- } \\
\text { ken, Miller, and Stevens } \\
\text { (1964). }\end{array}$ \\
\hline $\begin{array}{l}M-1603 \\
M-1626\end{array}$ & & Crane and Griffin (1966). \\
\hline
\end{tabular}


TABLE 2.-Selected radiocarbon ages and sources-Continued

\begin{tabular}{|c|c|c|}
\hline Lab No. & Age & Sources \\
\hline$M-1743$ & $11,200 \pm 400$ & Crane and Griffin (1968). \\
\hline M-1745 & $10,450 \pm 400$ & Do. \\
\hline M-1746 & $10,730 \pm 400$ & Do. \\
\hline M-1753-2 & $10,700 \pm 350$ & Do. \\
\hline M-1753-3 & $10,700 \pm 350$ & Do. \\
\hline M-1780 & $10,750 \pm 400$ & Do. \\
\hline M-1781 & $10,750 \pm 400$ & Do. \\
\hline M-1782 & $10,400 \pm 400$ & Do. \\
\hline M-1807 & $10,890 \pm 350$ & Do. \\
\hline M-2147 & $11,550 \pm 400$ & Crane and Griffin (1972). \\
\hline M-2186 & $10,300 \pm 340$ & Do. \\
\hline OWU-83 & $14,780 \pm 192$ & Ogden and Hay (1965). \\
\hline OWU-126 & $10,654 \pm 188$ & Do. \\
\hline OWU-165 & $10,680 \pm 210$ & Ogden and Hay (1967). \\
\hline OWU-166-A & $10,770 \pm 100$ & Do. \\
\hline OWU-168 & $13,911 \pm 418$ & Sears (1967). \\
\hline \multirow[t]{2}{*}{ OWU-168-A } & $13,530 \pm 420$ & Ogden and Hay (1967). \\
\hline & $15,172 \pm 746$ & Sears (1967). \\
\hline OWU-168-B & $14,790 \pm 420$ & Ogden and Hay (1967). \\
\hline OWU-189 & $11,500 \pm 360$ & Do. \\
\hline OWU-201 & $10,330 \pm 435$ & $\begin{array}{l}\text { Gilliam, Kapp, and Bogue (1967); } \\
\text { Ogden and Hay (1967). }\end{array}$ \\
\hline \multirow[t]{2}{*}{ OWU-240 } & $11,750 \pm 270$ & $\begin{array}{l}\text { Ogden and Hay (1969); Williams } \\
\text { (1974). }\end{array}$ \\
\hline & $12,670 \pm 270$ & Do. \\
\hline \multirow[t]{2}{*}{ OWU-241 } & $13,375 \pm 610$ & Do. \\
\hline & $14,295 \pm 610$ & Do. \\
\hline OWU-242 & $13,265 \pm 520$ & Do. \\
\hline OWU-302 & $10,915 \pm 205$ & Ogden and Hay (1969). \\
\hline OWU-304 & $10,595 \pm 370$ & Do. \\
\hline OWU-487 & $10,890 \pm 275$ & $\begin{array}{l}\text { Ogden and Hay (1973); Ogden } \\
\text { and Hart (1976). }\end{array}$ \\
\hline QC-149 & $11,590 \pm 265$ & Pardi (1977). \\
\hline QC-153 & $11,230 \pm 200$ & Do. \\
\hline QC-199 & $10,300 \pm 180$ & Cronin (1977); Pardi (1977). \\
\hline $\mathrm{QC}-200$ & $11,665 \pm 175$ & Do. \\
\hline QU-50 & $10,500 \pm 270$ & Hillaire-Marcel $(1973,1974 a)$. \\
\hline QU-51 & $11,340 \pm 300$ & Do. \\
\hline QU-55 & $11,050 \pm 460$ & Richard and Poulin (1976). \\
\hline QU-73 & $10,000 \pm 170$ & Rondot (1974). \\
\hline QU-74 & $10,430 \pm 220$ & Hillaire-Marcel $(1973,1974 a)$ \\
\hline QU-75 & $10,700 \pm 210$ & $\begin{array}{l}\text { Hillaire-Marcel }(1973,1974 a) ; \\
\text { Lowdon and Blake }(1975) .\end{array}$ \\
\hline QU-93 & $12,230 \pm 250$ & Richard and Poulin (1976). \\
\hline QU-112 & $12,120 \pm 260$ & Do. \\
\hline RL-157 & $13,470 \pm 850$ & $\begin{array}{l}\text { Newman (1973); Newman and } \\
\text { Pike (1975); Tucek (1977). }\end{array}$ \\
\hline S-29 & $11,400 \pm 450$ & $\begin{array}{l}\text { McCallum and Dyck (1960); Drei- } \\
\text { manis (1966a); Lewis, Ander- } \\
\text { son, and Berti (1966). }\end{array}$ \\
\hline S-30 & $12,000 \pm 500$ & $\begin{array}{l}\text { McCallum and Dyck (1960); Drei- } \\
\text { manis (1966a). }\end{array}$ \\
\hline S-31 & $12,660 \pm 440$ & McCallum (1955); Dreimanis and \\
\hline & & $\begin{array}{l}\text { Terasmae (1958); Dreimanis } \\
(1958,1966 \mathrm{a}, 1966 \mathrm{~b}) ; \text { Calkin } \\
(1970) \text {. }\end{array}$ \\
\hline S-172 & $12,000 \pm 200$ & $\begin{array}{l}\text { Dreimanis (1964b); McCallum } \\
\text { and Wittenburg (1965); Dyck, } \\
\text { Fyles, and Blake (1966); Lewis, } \\
\text { Anderson, and Berti (1966). }\end{array}$ \\
\hline
\end{tabular}

TABLE 2.-Selected radiocarbon ages and sources-Continued

\begin{tabular}{|c|c|c|}
\hline Lab No. & Age & Sources \\
\hline$V-29$ & $11,660 \pm 135$ & Bermingham (1966). \\
\hline W-33 & $13,600 \pm 500$ & $\begin{array}{l}\text { Suess (1954); Flint and Rubin } \\
\text { (1955); Hough (1958); } \\
\text { Goldthwait (1958); Dreimanis } \\
\text { (1966)); Calkin (1970). }\end{array}$ \\
\hline$W-42$ & $11,350 \pm 120$ & $\begin{array}{l}\text { Suess (1954); Hough (1958); } \\
\text { Black and Rubin (1968). }\end{array}$ \\
\hline W-57 & $12,380 \pm 370$ & Suess (1954); Goldthwait (1958). \\
\hline W-58 & $12,380 \pm 370$ & $\begin{array}{l}\text { Suess (1954); Flint and Rubin } \\
\text { (1955); Wayne (1963). }\end{array}$ \\
\hline W-64 & $13,140 \pm 400$ & $\begin{array}{l}\text { Suess (1954); Flint and Rubin } \\
\text { (1955); Thornbury (1958); } \\
\text { Wayne (1963). }\end{array}$ \\
\hline W-65 & $13,020 \pm 400$ & $\begin{array}{l}\text { Suess (1954); Flint and Rubin } \\
\text { (1955); Goldthwait (1958); } \\
\text { Wayne (1963). }\end{array}$ \\
\hline W-83 & $11,410 \pm 180$ & $\begin{array}{l}\text { Suess (1954); Hough (1958); } \\
\text { Black and Rubin (1968). }\end{array}$ \\
\hline $\mathrm{W}-140$ & $12,650 \pm 350$ & $\begin{array}{l}\text { Rubin and Suess (1955); Flint } \\
\text { and Rubin (1955); Hough } \\
\text { (1958). }\end{array}$ \\
\hline W-161 & $12,200 \pm 350$ & Do. \\
\hline W-167 & $10,860 \pm 350$ & $\begin{array}{l}\text { Rubin and Suess (1955); Zum- } \\
\text { berge and Potzger (1956); } \\
\text { Hough (1958); Broecker and } \\
\text { Farrand (1963). }\end{array}$ \\
\hline W-198 & $14,300 \pm 450$ & $\begin{array}{l}\text { Rubin and Suess (1955); Flint } \\
\text { and Rubin (1955); Goldthwait } \\
\text { (1958). }\end{array}$ \\
\hline W-346 & $13,000 \pm 300$ & $\begin{array}{l}\text { Rubin and Alexander (1958); } \\
\text { Droste, Rubin, and White } \\
\text { (1959); White, Totten, and } \\
\text { Gross (1969). }\end{array}$ \\
\hline W-365 & $14,000 \pm 350$ & Do. \\
\hline $\mathrm{W}-426$ & $10,700 \pm 300$ & Rubin and Alexander (1958). \\
\hline $\mathrm{W}-430$ & $12,920 \pm 400$ & $\begin{array}{l}\text { Goldthwait (1958); Rubin and } \\
\text { Alexander (1958); Dreimanis } \\
\text { (1966b); Calkin (1970). }\end{array}$ \\
\hline W-507 & $12,000 \pm 300$ & $\begin{array}{l}\text { Rubin and Alexander (1960); } \\
\text { Muller (1960, 1963); Calkin } \\
\text { (1970). }\end{array}$ \\
\hline $\mathrm{W}-670$ & $12,200 \pm 400$ & $\begin{array}{l}\text { Rubin and Alexander (1960); } \\
\text { Black and Rubin (1968). }\end{array}$ \\
\hline W-698 & $11,550 \pm 300$ & Do. \\
\hline W-861 & $12,660 \pm 400$ & $\begin{array}{l}\text { Rubin and Alexander (1960); } \\
\text { Calkin (1970). }\end{array}$ \\
\hline W-883 & $12,080 \pm 300$ & $\begin{array}{l}\text { Rubin and Berthold (1961); Calkin } \\
\text { (1970). }\end{array}$ \\
\hline W-1038 & $10,450 \pm 400$ & $\begin{array}{l}\text { Ives, Levin, Robinson, and Rubin } \\
\text { (1964). }\end{array}$ \\
\hline W-1109 & $10,560 \pm 350$ & $\begin{array}{l}\text { Ives, Levin, Robinson, and Rubin } \\
\text { (1964); Denny (1974). }\end{array}$ \\
\hline W-1230 & $10,650 \pm 350$ & $\begin{array}{l}\text { Levin, Ives, Oman, and Robin } \\
\text { (1965). }\end{array}$ \\
\hline W-1847 & $12,500 \pm 500$ & $\begin{array}{l}\text { Farrand, Zahner, and Benning. } \\
\text { hoff (1969). }\end{array}$ \\
\hline W-1889 & $12,570 \pm 500$ & $\begin{array}{l}\text { Farrand, Zahner, and Benning. } \\
\text { hoff (1969); Marsters, Spiker, } \\
\text { and Rubin (1969). }\end{array}$ \\
\hline W-2251 & $11,220 \pm 400$ & $\begin{array}{l}\text { Spiker, Kelley, Oman, and Rubin } \\
\text { (1977). }\end{array}$ \\
\hline
\end{tabular}


TABLE 2,-Selected radiocarbon ages and sources-Continued

\begin{tabular}{|c|c|c|}
\hline Lab No. & Age & Sources \\
\hline W-2309 & $10,950 \pm 300$ & Wagner (1972). \\
\hline W-2311 & $11,420 \pm 350$ & Do. \\
\hline W-2562 & $12,300 \pm 300$ & Sirkin and Minard (1972). \\
\hline WIS-2 & $12,800 \pm 450$ & $\begin{array}{l}\text { Bender, Bryson, and Baerreis } \\
\text { (1965). }\end{array}$ \\
\hline WIS-347 & $12,410 \pm 100$ & $\begin{array}{l}\text { Maher (1970); Bender, Bryson, } \\
\text { and Baerreis (1970); Evenson } \\
\text { and Mickelson (1974). }\end{array}$ \\
\hline WIS-462 & $12,360 \pm 125$ & $\begin{array}{l}\text { Bender, Bryson, and Baerreis } \\
\text { (1971); Evenson and Mickel- } \\
\text { son (1974). }\end{array}$ \\
\hline WIS-507 & $12,060 \pm 120$ & $\begin{array}{l}\text { Bender, Bryson, and Baerreis } \\
\text { (1975). }\end{array}$ \\
\hline WIS-614 & $\begin{array}{l}11,295 \pm 110 \\
11,425 \pm 110\end{array}$ & $\begin{array}{l}\text { Ogden and Hart (1977). } \\
\text { Do. }\end{array}$ \\
\hline WIS-640 & $10,225 \pm 85$ & $\begin{array}{l}\text { Bender, Bryson, and Baerreis } \\
\text { (1975). }\end{array}$ \\
\hline WIS-641 & $11,620 \pm 110$ & Do. \\
\hline WIS-646 & $10,440 \pm 95$ & Do. \\
\hline WIS-663 & $15,215 \pm 115$ & Do. \\
\hline WIS-664 & $11,845 \pm 115$ & Do. \\
\hline WIS-672 & $\begin{array}{l}11,295 \pm 110 \\
11,425 \pm 110\end{array}$ & $\begin{array}{l}\text { Do. } \\
\text { Do. }\end{array}$ \\
\hline WIS-676 & $13,065 \pm 125$ & $\begin{array}{l}\text { Bender, Bryson, and Baerreis } \\
\text { (1975); Odgen and Hart (1977). } \\
\text { Do. }\end{array}$ \\
\hline Y-215 & $10,630 \pm 330$ & $\begin{array}{l}\text { Preston, Person, and Deevey } \\
\text { (1955); Hough (1958); Gadd } \\
(1964,1971) \text {; Mott (1968). }\end{array}$ \\
\hline $\mathrm{Y}-216$ & $10,850 \pm 330$ & $\begin{array}{l}\text { Preston, Person, and Deevey } \\
\text { (1955); Hough (1958); Mott } \\
\text { (1968); Gadd (1971). }\end{array}$ \\
\hline Y-227 & $11,130 \pm 350$ & $\begin{array}{l}\text { Preston, Person, and Deevey } \\
\text { (1955); Thwaites and Bertrand } \\
\text { (1957); Hough (1958); Black } \\
\text { and Rubin (1968). }\end{array}$ \\
\hline $\mathrm{Y}-233$ & $11,370 \pm 360$ & $\begin{array}{l}\text { Preston, Person, and Deevey } \\
\text { (1955); Hough (1958); Gadd } \\
\text { (1964). }\end{array}$ \\
\hline Y-240 & $12,800 \pm 250$ & $\begin{array}{l}\text { Barendsen, Deevey, and Gralen- } \\
\text { ski (1957); Goldthwait (1958); } \\
\text { Hough (1958). }\end{array}$ \\
\hline Y-293-A & $10,790 \pm 20,0$ & $\begin{array}{l}\text { Preston, Person, and Deevey } \\
\text { (1955); corrected in Flint } \\
\text { (1956) and Hough (1958). }\end{array}$ \\
\hline Y-293-B & $10,550 \pm 150$ & $\begin{array}{l}\text { Preston, Person, and Deevey } \\
\text { (1955); Flint (1956); Hough } \\
\text { (1958); Broecker and Farrand } \\
\text { (1963). }\end{array}$ \\
\hline$Y-460$ & $11,410 \pm 410$ & $\begin{array}{l}\text { Cox (1959); Deevey, Gralenski, } \\
\text { and Hoffren (1959). }\end{array}$ \\
\hline Y-691 & $11,570 \pm 260$ & $\begin{array}{l}\text { Stuiver, Deevey, and Gralenski } \\
\text { (1960); Karrow, Clark, and } \\
\text { Terrasmae (1961); Karrow } \\
\text { (1963); corrected in Stuiver } \\
\text { (1969). }\end{array}$ \\
\hline$Y-1558$ & $10,560 \pm 160$ & LaSalle (1966); Mott (1968). \\
\hline$Y-1893$ & $13,660 \pm 200$ & Williams (1974). \\
\hline$Y-2619$ & $13,320 \pm 200$ & Coates, Landry, and Lipe (1971). \\
\hline
\end{tabular}

TABLE 2.-Selected radiocarbon ages and sources-Continued

\begin{tabular}{|c|c|c|}
\hline Lab No. & Age & Sources \\
\hline \multicolumn{3}{|c|}{ Laboratory numbers not designated } \\
\hline & $10,200 \pm 400$ & Schaffel (1971). \\
\hline & $10,305 \pm 78$ & Sly and Lewis (1972). \\
\hline & $10,900 \pm$ & $\begin{array}{l}\text { Calkin, Brett, and Krajewski } \\
\text { (1975). }\end{array}$ \\
\hline Gx & $11,700 \pm 250$ & $\begin{array}{l}\text { Tovell and Deane (1966); Har- } \\
\text { rison (1972). }\end{array}$ \\
\hline TBN & $11,900 \pm 350$ & Stoutamire and Benninghoff \\
\hline & & $\begin{array}{l}\text { (1964); Dorr and Eschman } \\
\text { (1970). }\end{array}$ \\
\hline I & $12,000 \pm 190$ & $\begin{array}{r}\text { Maher (1970); Lasca (1970b); Ev- } \\
\text { enson and Mickelson (1974). }\end{array}$ \\
\hline
\end{tabular}

includes only the experimental standard deviations of the count rate of the sample, the modern standard (commonly 95 percent National Bureau of Standards oxalic-acid standard), and the background. In some instances the ages have been corrected for carbonisotope fractionation, the de Vries effect, modern surface-sample age anomalies, and other factors. The references in table 2 should be consulted to determine the method of calculation of the age and error of a specific sample.

The ages of the youngest events in chart columns 1 through 5 (pl. 1) are not closely controlled by radiocarbon age measurements. An age of 10,000 B.P. was arbitrarily chosen as a younger limit of ages included on the chart; all radiocarbon ages younger than 10,000 B.P. have been omitted from the chart and table 2 . If replicate ages have been reported for a sample, all the measured ages older than 10,000 B.P. are shown on the chart and in table 2. Many authors have referenced only the oldest of replicate ages, although the oldest age is not necessarily more reliable than other measurements. If corrections for modern surfacesample age anomalies have been applied to measured ages, both the measured ages and the corrected ages are listed on the chart (pl. 1) and in table 2.

The nonlinear time scale on the left and right side of the chart (pl. 1) (estimated ${ }^{14} \mathrm{C}$ age) was constructed on the basis of the radiocarbon ages on the chart and time-distance diagrams of ice-margin fluctuations in different glacial lobes. Vertical spacing of events on the chart was dictated by space requirements of the included information.

Placement of radiocarbon ages on the chart was governed by the stratigraphic positions of the samples in relation to sediments that record specific events and by the chronologic restraints imposed by stratigraphic considerations. Placement was not necessarily dictated by the significance assigned to the ages by other authors. 
Most radiocarbon ages place constraints on the age of one or more events, but do not necessarily provide the age of an event. Radiocarbon ages that provide critical maximum or minimum ages for events are listed on the chart as "greater than" or "less than," depending upon the stratigraphic relationships of the samples to sediments that record specific events. Ages that possibly are merely bracketing ages but may actually date an event are listed as "greater than or equal to" or "less than or equal to." For example, in column 2, GSC-1111 and GSC-1644 are from stratigraphic horizons that postdate extinction of Late Lake Algonquin; consequently, the age of Late Lake Algonquin is shown as $>10,200 \pm 150$ (GSC-1111) and $>10,300 \pm 200$ (GSC-1644). Samples GSC-1126 and GSC-1127 are from horizons that may postdate Late Lake Algonquin extinction or may have been deposited shortly prior to extinction; consequently, the age of Late Lake Algonquin also is shown as $\geqslant 10,500 \pm 150$ (GSC-1126) and $\geqslant 10,600 \pm 160$ (GSC-1127).

The resolution of radiocarbon age measurements is insufficient to permit radiocarbon ages to be used as a principal basis of a chronologic or correlation scheme in the Great Lakes region, in spite of the assumed accuracy of measured ages and the precision implied by the statistical errors of measured ages. If only a single age is available for an event, it is tempting to use that age as the basis for correlation with an event represented by a similar radiocarbon age in another region. If three or more ages are available for an event, commonly they are not internally consistent, thus making more than one correlation on the basis of measured ages possible. In some instances the precise age of an event has become increasingly obscure as more radiocarbon ages have been obtained (for example, see Lake Wayne in column 3 on plate 1).

Many of the radiocarbon ages on plate 1 are ages of basal organic materials in bogs or swamps that overlie sediments that are records of glacial or deglacial events. As such, the organic materials provide minimum ages of the events. Most of the minimum ages of end moraines and tills in columns 2 and 3 on plate 1 are bog ages. Nearly all the latter ages are $1,000-5,000$ radiocarbon years younger than the inferred ages of the end moraines or tills. It is apparent that very few bog-bottom ages in Indiana, Michigan and Ohio provide closely limiting ages of glacial or deglacial events and that no specific span of time can be assumed to have intervened between deglaciation and initial deposition of organic materials in bogs and swamps. Consequently, there is no reason to assume that any of the bog-bottom ages in columns 4,5 , and 9 on plate 1 necessarily provide closely limiting ages of deglacial events in New Jersey and New York.

\section{GLACIAL TILLS}

Most of the tills from the United States are designated by informal names on the chart because they have not been described and defined as formal rockstratigraphic units in accordance with specifications of the Code of Stratigraphic Nomenclature (American Commission on Stratigraphic Nomenclature, 1961). All informal names of tills are enclosed in quotation marks. The following tills are recognized here as formal rock-stratigraphic units.

a. The Wadsworth and Haeger Till Members of the Wedron Formation, Illinois (Willman and Frye, 1970; Frye and Willman, 1975),

b. The Shorewood and Manitowoc Till Members of the Wedron Formation, Illinois (Lineback and others, 1974),

c. The Two Rivers Till, Wisconsin (Evenson, 1973a, 1973b),

d. The New Holland Till Member of the Lagro Formation, Huron lobe, Indiana (Wayne, 1963, 1968),

e. The Hayesville Till, Killbuck sublobe, Ohio (White, 1961, 1967),

f. The Lavery, Hiram, and Ashtabula Tills, Grand River sublobe, Ohio, and Erie lobe, Pennsylvania (Shepps and others, 1959; White, 1960, 1961, 1969; White and others, 1969).

The following tills are recognized as informal rockstratigraphic units on the chart (pl. 1) and in the "Supplementary Notes" section:

a. The Port Huron till, Huron lobe and Saginaw sublobe, Michigan (Dorr and Eschman, 1970; Farrand and Eschman, 1974);

b. The Tymochtee and Lake tills, Erie lobe, Ohio (Goldthwait and Rosengreen, 1969; Dreimanis and Goldthwait, 1973);

c. The Darby till, Scioto sublobe, Ohio (Goldthwait and others, 1965; Goldthwait and Rosengreen, 1969; Dreimanis and Goldthwait, 1973; Rosengreen, 1974);

d. The Centerburg till, Scioto sublobe, Ohio (Forsyth, 1961, 1967);

e. The Lake Escarpment and Valley Heads tills, Erie and Ontario lobes, New York (Muller, 1963, 1965a; Calkin, 1970; Coates, 1976);

f. The Mohawk and Indian Castle tills, Mohawk Lowland and northern Appalachian Plateau, New York (LaFleur, 1969; Fullerton, 1971; Krall, 1972, 1977; Coates, 1976);

g. The Malone and Fort Covington tills, Black River Lowland and St. Lawrence Lowland, New York (MacClintock, 1954a, 1958; MacClintock and Terasmae, 1960; MacClintock and Stewart, 1965);

h. The Shelburne and Burlington tills, Vermont (Stewart and MacClintock, 1969, 1970, 1971).

None of these tills has been defined according to provisions of Articles 4, 10, and 13 of the Code of Stratigraphic Nomenclature (American Commission on Stratigraphic Nomenclature, 1961).

The "Centerburg till" was defined solely on the basis of the areal distribution of a surface-soil catena. The "till" was not described or defined in terms of lithology, texture, or stratigraphic position, and no evidence was presented to demonstrate that the "till" with the distinctive soil profile is younger than other "tills" in the same region on which other soil catenas have developed (Forsyth, 1961, 1967). 
The terms "Lake Escarpment till" and "Valley Heads till" refer to the material (till) that comprises the several imbricated end moraines in the Lake Escarpment and Valley Heads moraine systems. The end moraines in the respective systems are composed of or are veneered by different (unnamed) rock-stratigraphic units in different places. The terms are not applied to the same materials (tills) in the lowlands north of the moraine systems. The terms "Lake Escarpment" and "Valley Heads" have a morphologic (physiographic) connotation; they have no rock-stratigraphic significance.

The Malone and Fort Covington tills are discussed in Supplementary Note 36 , and the Shelburne and Burlington tills are discussed in Supplementary Note 45.

Problems of application of stratigraphic terminology to glacial and deglacial sediments are many and complex (Frye and Leonard, 1953; Luittig, 1958, 1965; Richmond, 1959; Morrison, 1968; Jardin, 1972; Mangerud and others, 1974). For example, till is deposited during recession of an ice margin as well as during its advance. In practice, the time interval represented by deglacial or nonglacial sediments (outwash, lake sediments, loess, alluvium) between two tills at a specific locality is referred to as an interstadial. If an ice margin readvanced following an interval of significant recession, initial deposition of the younger till at some localities occurred during the later part of an interstadial at other localities. Boundaries between tills that occur in stratigraphic succession are assigned to a single time on the chart; consequently, the boundaries are shown to coincide with times of maximum icemargin recession-that is, at the times of initial readvance of the ice margins.

Correlations of tills and correlations of end moraines are hampered by a lack of detailed stratigraphic information from Michigan, northeastern Indiana, northwestern and north-central Ohio, New Jersey, and most of New York. Nearly all reconstructions of events in these regions must rely heavily upon morphologic criteria.

\section{END MORAINES}

All the end moraines listed on the chart were formed at least in part as a result of significant readvances or stillstands of ice margins; most were formed entirely as a result of a single readvance or stillstand. Although local evidence of overridden or palimpsest moraines is common in the Great Lakes region (White, 1962; Totten, 1969, 1973; Bleuer, 1974a; Karrow, 1974a), the same moraines in other places are composed of a single till. The author concurs with Wright's $(1976$, p. 128 ,
130) conclusion that “**** there is no real reason to challenge the basic assumption of Chamberlin and the other early glacial geologists that a moraine represents a stillstand or sometimes a readvance of the ice $* * *$."

Times of culmination of significant glacial readvances (represented in many instances by formation of end moraines, and in some instances only by till-sheet boundaries) are indicated on the chart (pl. 1) by a diagonal line pattern $(T / 7 / 7 /$ ) beneath the names of the moraines (for example, the Outer Port Huron and Wyoming moraines in column 2). Many moraines that are not so designated also were formed as a result of readvances, but the magnitudes of the readvances are not known and the moraines may be products of local ice-margin fluctuations. Many named end moraines in the Great Lakes region and in the Lowlands are not listed on the chart.

\section{ALTITUdES OF LAKE PHASES}

Altitudes shown for many lake phases in the Michigan, Huron, and Erie lake basins are those indicated by strand features south of hypothetical isobases of zero postglacial uplift. Others are extrapolated altitudes of water levels in so-called stable areas, as inferred from reconstructed differential uplift profiles. Altitudes of Lakes Dana, Tonawanda, and Iroquois in western New York and glacial lakes in central New York and the Mohawk and Black River Lowlands are present altitudes of strands or lake outlets, as are altitudes of Early Lake Saginaw phases in the Lake Huron basin. Altitudes of Lakes Albany, Quaker Springs, Coveville, and Fort Ann I, in the Hudson and Champlain Lowlands, are the present altitudes of strands in the vicinity of Troy, N.Y., as reported by LaFleur (1965c) (Supplementary Note 40).

\section{SUPPLEMENTARY NOTES}

The numbered notes that accompany the chart (pl. 1) are intended to explain the reasons for selected correlations and to focus attention on inconsistent interpretations and selected unsolved problems. A detailed critique of previous correlation schemes, a systematic discussion of all the evidence on which the current correlations are based, and a discussion of the relative merits of alternative interpretations of available data would require a monographic text and a much more comprehensive list of references than that presented here.

\section{SELECTED REFERENCES}

More than 2,500 references were consulted in compiling the chart. The selected references included here 
represent the spectrum of studies that were consulted in an attempt to obtain the observational field data necessary to propose detailed correlations of post-Erie interstadial events in the Great Lakes region and in the Hudson, Champlain, and St. Lawrence Lowlands. Many of the observational field data upon which earlier syntheses of Great Lakes history were based were published more than 50 years ago, and the original sources have not been referenced in more recent summaries. Unpublished dissertations, theses, open-file reports, and manuscripts also contain a large body of very significant field data. Consequently, selected important early publications by W. C. Alden, F. C. Baker, Frank Carney, A. P. Coleman, H. L. Fairchild, J. W. Goldthwait, W. A. Johnston, Frank Leverett, I. C. Russell, W. H. Sherzer, J. W. Spencer, F. B. Taylor, Warren Upham, and other pioneer workers, as well as more recent dissertations, theses, open-file reports, and manuscripts, are included in the list of references in the hope that they will be useful to students and other workers who may wish to rediscover the basic data upon which correlations have been based during the past half century.

\section{ACKNOWLEDGMENTS}

Compilation of data from New York State was begun in 1969 at the request of Donald R. Coates and Sheldon Judson. A simplified preliminary chart of correlations in New York was included in a doctoral dissertation (Fullerton, 1971) at Princeton University. Subsequent revisions and expansions of the chart have been distributed informally through the "Glaciogram", at the request of Donald R. Coates, Parker E. Calkin, and Ernest H. Muller.

Many helpful suggestions, valuable criticisms, and new information have been offered by Parker $\mathbf{E}$. Calkin, Andrew J. Cooper, William R. Cowan, Aleksis Dreimanis, William R. Farrand, Bernie H. Feenstra, Q. H. J. Gwyn, Paul F. Karrow, Barrie C. McDonald, Ernest H. Muller, Walter S. Newman, and Victor K. Prest. The author assumes full responsibility for correlations and interpretations presented here and for any inadvertent misrepresentation of observational data from cited references.

\section{SUPPLEMENTARY NOTES}

(Numbers correspond to circled numbers on plate 1)

NOTE 1

The name "Greatlakean Substage" was proposed as a replacement for the Valderan Substage (Evenson and others, 1976; Evenson and Dreimanis, 1976). The intent was to rename, rather than redefine, the substage (Evenson and others, 1976, 1978). Revision of the deglaciation history of the Lake Michigan basin also was proposed by Evenson and his colleagues. They suggested that (A) ice-margin recession during the Twocreekan Substage was not as extensive as formerly supposed (the Straits of Mackinac were not deglaciated); (B) the duration of the Twocreekan Substage was much shorter than previous workers had assumed, and the significance of the substage in Wisconsinan classification and chronology has been overemphasized; and (C) the magnitude of the postTwocreekan glacial readvance (recorded by the Two Rivers Till) was not as great as previous workers had assumed. The latter interpretations are greatly dependent upon the validity of the Cary-Port Huron (Mackinaw) interstadial age assigned to the Cheboygan bryophte bed in Michigan by Farrand, Zahner, and Benninghoff (1969); the age and correlation of the bryophyte bed are not firmly established (Supplementary Notes 11 and 14).

\section{NOTE 2}

For review of the Valders controversy in Wisconsin and Michigan, see Black (1966, 1969, 1970a, 1974a, $1974 b, 1976,1978)$, Maher (1970), Evenson (1972, 1973a, 1973b), Mickelson (1973), Evenson, Eschman, and Farrand (1973b), Evenson, Farrand, and Eschman (1974), Evenson and Mickelson (1974), Mickelson and Evenson (1975), and Evenson, Farrand, Eschman, Mickelson, and Maher $(1976,1978)$. (Also see Supplementary Notes 1 and 14.)

The Shorewood and Manitowoc Till Members of the Wedron Formation on the floor of Lake Michigan (Lineback and others, 1974) have not been traced on land to the type area of the Valders Till in Wisconsin (Evenson and others, 1976; Black, 1978), and the Valders controversy will not be solved until the stratigraphic relationship of the type Valders Till to the Shorewood and Manitowoc Till Members is determined.

NOTE 3

The name Two Rivers Till (Evenson, 1972, 1973a, $1973 \mathrm{~b}$ ) is applied to the Michigan lobe till that overlies the Two Creeks buried forest in Wisconsin (Evenson and others, 1976; Evenson and Dreimanis, 1976; Johnson, 1976). The type Valders Till is assumed to be older than the Two Creeks forest. 
NOTE 4

The radiocarbon ages listed are from the type area of the Two Creeks forest and the Ernst Brothers section in the Michigan lobe area of Wisconsin. Ages from deposits of inferred correlative age in the Green Bay lobe are not included.

The Ernst Brothers section is approximately $125 \mathrm{~km}$ (kilometers) south of the Two Creeks section and is in a region that was not inundated by Lakes Chicago and Algonquin. The lower of two buried forests was correlated tentatively with the Two Creeks buried forest on the basis of pollen analysis, but initial growth of the lower forest may have antedated initial growth of the Two Creeks forest (Maher, 1970). The three radiocarbon ages from the Ernst Brothers section listed on the chart are 12,500 \pm 120 (ISGS-75), 12,410 \pm 100 (WIS-347), and 12,000 \pm 190 (Isotopes, Inc). Note that ISGS-75 and WIS-347 are the two oldest "Twocreekan" ages listed. Only five measured radiocarbon ages from the Two Creeks buried forest are older than 12,000 B.P.: $12,200 \pm 400$ (W-670), $12,168 \pm 1,500 \quad(\mathrm{C}-536), \quad 12,150 \pm 400 \quad(\mathrm{~A}-79-\mathrm{A})$, $12,060 \pm 120$ (WIS-507), and 12,020 \pm 110 (ISGS-76). The standard deviations of the ages permit an assumption that initial growth of the Two Creeks forest began no earlier than 12,000 B.P., and perhaps as late as 11,950 B.P., as suggested by Broecker and Farrand (1963).

The Kirkfield phase of Lake Algonquin was established in the Lake Huron basin before initial growth of the Two Creeks forest occurred in Wisconsin, and drowning of the forest occurred before the Kirkfirld phase was extinguished in the Lake Huron basin. Published data suggest that the Kirkfield phase may have persisted for no longer than 400 years; hence, forest growth represents a shorter time interval (Evenson and others, 1976, fig. 2). On the other hand, ring counts indicate that forest growth spanned an interval of at least 142 years (Black, 1970a). On the basis of selected radiocarbon samples, Broecker and Farrand (1963) concluded that growth of the forest occurred within a time interval of 200 radiocarbon years (11,950-11,750 B.P.). The age span suggested by Broecker and Farrand is reasonable, in light of regional considerations, although the ages measured by the authors are not necessarily more reliable than are other ages measured by other laboratories.

\section{NOTE 5}

Farrand and Eschman (1974), Evenson, Farrand, Eschman, Mickelson, and Maher (1976), and Evenson and Dreimanis (1976) tentatively correlated the Manitowoc Till Member of the Wedron Formation on the floor of Lake Michigan (Lineback and others, 1974) with the till that comprises the Manistee and Inner Port Huron moraines in Michigan. The stratigraphic relationship of the Manitowoc Till Member in Lake Michigan to tills in Wisconsin has not been demonstrated (Evenson and others, 1976; Black, 1978).

\section{NOTE 6}

Glenwood phase of Lake Chicago strands north of the Manistee moraine and the association of the moraine with pitted outwash graded to the Glenwood level (Evenson, 1972, 1973a, 1973b) indicate that the Manistee moraine was formed prior to inception of the Calumet phase of Lake Chicago. An outwash channel inset into the pitted outwash but graded to the Calumet level (Evenson, 1972, 1973a) suggests that the Glenwood-Calumet transition occurred very shortly after formation of the Manistee moraine. The Inner Port Huron and Bay City moraines are products of a glacial readvance that occurred during the existence of Lake Warren $I$ in the Huron and Erie lake basins (Bretz, 1951a; Hough, 1958, 1963), and at least part of the Lake Warren I drainage through the Grand Valley entered the Calumet phase of Lake Chicago (Eschman and Farrand, 1970; Farrand and Eschman, 1974). The drainage relationships indicate only that the Calumet level was established prior to extinction of Lake Warren I; early drainage from Lake Warren I may have entered the Glenwood II phase of Lake Chicago. The relationships of the Manistee, Inner Port Huron, and Bay City moraines to the Glenwood and Calumet phases of Lake Chicago and to Lake Warren I establish an important time line for correlations of other events in the Michigan, Huron, and Erie lake basins. Taylor (1977) confirmed that the Two Rivers Till represents a glacial readvance after formation of the Inner Port Huron moraine near Manistee, and he found Glenwood phase Lake Chicago(?) sediments beneath the Two Rivers Till.

NOTE 7

Farrand and Eschman (1974), Evenson, Farrand, Eschman, Mickelson, and Maher (1976), and Evenson and Dreimanis (1976) tentatively correlated the end moraine associated with the southern limit of the Shorewood Till Member of the Wedron Formation, on the floor of Lake Michigan (Lineback and others, 1974), with the Whitehall and Outer Port Huron moraines in Michigan. The stratigraphic relationship of the Shorewood Till Member in Lake Michigan to tills in Wisconsin has not been determined (Evenson and others, 1976; Black, 1978). 
NOTE 8

Correlation of the interval between times of deposition of the Yorkville and Wadsworth Till Members of the Wedron Formation (the "St. Charles intraglacial" of Leighton, 1960) in Illinois with the Erie interstadial in the Lake Erie basin (Frye and Willman, 1973) is reasonable in light of published data from Illinois and Indiana. The more recent assignment of the Jules Soil to the Erie interstadial (Frye and others, 1974) requires correlation of the Malden and Snider Till Members (and possibly part of the Batestown Till Member) of the Wedron Formation in Illinois with the New Holland Till Member of the Lagro Formation in northeastern Indiana (Johnson, 1976). Till stratigraphy and crosscutting relationships of end moraines in Indiana preclude the latter correlation (Wayne, 1958, 1963, 1965a; Bleuer, 1974b, 1975; Moore, 1974; Johnson, 1976). Both the age and the stratigraphic significance of the Jules Soil have been questioned (Ruhe, 1976; Johnson, 1976). The Wadsworth and Haeger Till Members of the Wedron Formation here are considered to be the oldest tills deposited in Illinois during the Port Bruce stadial in the Lake Erie basin timestratigraphic scheme of Dreimanis and Karrow (1972).

NOTE 9

Correlation of the six named end moraines of the Valparaiso moraine system in Illinois (Willman and Frye, 1970) with specific end moraines in Michigan has not been established on the basis of till stratigraphy. Morphologic interpretations of Leverett and Taylor (1915), Zumberge (1960), Wayne and Zumberge (1965), Dorr and Eschman (1970), Farrand and Eschman (1974), and others differed greatly. Correlation of the West Chicago moraine with the Redfield-Three Rivers and Tekonsha moraines in Michigan on the chart is based on the relationship of the moraines to deposits and meltwater channels of the "Kankakee flood" in Illinois, Indiana, and Michigan, as outlined by Zumberge (1960) and Wayne and Zumberge (1965). (See Supplementary Note 18.)

\section{NOTE 10}

The history of Algonquin and post-Algonquin lake phases is extremely complicated. The ages and correlations of events in the Michigan and Huron lake basins cannot be resolved until the succesions of events in the respective basins are determined. It has not been proved whether extinction of the Kirkfield phase of Lake Algonquin was caused by differential uplift in the Lake Huron basin (Leverett and Taylor, 1915; Stanley, 1938a; Hough, 1958; Prest, 1970) or by a glacial read- vance in the Trent Valley in Ontario (Johnston, 1916a; Deane, 1950). Published field data are compatible with an interpretation that the Two Rivers readvance in Wisconsin and Michigan (Evenson and others, 1976) and the Lake Simcoe readvance in Ontario (Deane, 1950) were approximately synchronous. Uncertainties of the cause of extinction of the Kirkfield phase, the age of the Kirkfield-Late Lake Algonquin transition, the age of inception of the Toleston II phase of Lake Chicago, and the ages of the Two Rivers and Lake Simcoe glacial readvances permit several alternative schemes of correlation and chronology to be entertained. The scheme shown on the correlation chart is based on three assumptions: (a) extinction of the Kirkfield phase was caused by differential uplift, (b) the Kirkfield-Late Lake Algonquin transition occurred prior to isolation of Toleston II phase Lake Chicago in the Lake Michigan basin (as a result of the Two Rivers readvance), and (c) the Two Rivers and Lake Simcoe readvances were approximately synchronous.

The monograph by Leverett and Taylor (1915) is still the most comprehensive reference on the Algonquin and post-Algonquin lake history. Correlation schemes of Flint $(1947,1953,1957,1971)$, Hough $(1953,1958$, 1966, 1969), Wayne and Zumberge (1965), Kelley and Farrand (1967), Dorr and Eschman (1970), Prest (1970), Sly and Lewis (1972), and Farrand and Eschman (1974) differed greatly. Discussions and summaries by Deane (1950), Zumberge and Potzger (1956), Farrand (1962), Broecker and Farrand (1963), Wayne and Zumberge (1965), Chapman and Putnam (1966), Lewis (1969), Dorr and Eschman (1970), Harrison (1972), and Chapman (1975) contributed much to resolution of the "Algonquin problem," but each provided additional unanswered questions and a broader basis for postulation of alternative schemes of succession and correlation. Johnston (1916a), Deane (1950), Gravenor (1957), Mirynech (1962, 1967), Harrison (1970, 1972), and Chapman (1975) contributed stratigraphic and morphologic data that must be considered in any attempt to correlate the Algonquin and post-Algonquin phases in the Lake Huron basin with lakes in the Lake Ontario basin. Anderson (1971), Saarnisto (1974), and Karrow, Anderson, Clarke, Delorme, and Sreenivasa (1975) provided new paleoecological data and radiocarbon ages.

NOTE 11

Farrand, Zahner, and Benninghoff (1969), Farrand and Eschman (1974), and Evenson, Farrand, Eschman, Mickelson, and Maher (1976) concluded that a low-lake phase in the Lake Michigan basin (the "Two Creeks 
low-water stage" of Evenson and others, 1976) drained eastward to the Lake Huron basin, possibly by way of the Indian River lowland, east of Little Traverse Bay, Mich. Assignment of a Cary-Port Huron (Mackinaw) interstadial age to the Cheboygan bryophyte bed in Michigan and the apparent absence of a lithologic or stratigraphic break in the till that overlies the bryophyte bed (Farrand and others, 1969; Farrand and Eschman, 1974; Evenson and others, 1976) seemingly require that the Straits of Mackinac were not deglaciated at the time of growth of the Two Creeks forest in Wisconsin. If these interpretations are correct, the low phase in the Lake Michigan basin during the Two Creeks interstadial was higher than the initial Kirkfield phase of Lake Algonquin in the Lake Huron basin and the initial Kirkfield phase did not enter the Lake Michigan basin. Stratigraphic evidence indicating that waters in the Lake Michigan basin were higher than waters in the Lake Huron basin and stratigraphic evidence of drainage through the Indian River lowland have not been published. Leverett and Taylor (1915), Hough (1958, 1963), Wayne and Zumberge (1965), Dorr and Eschman (1970), Prest (1970), Flint (1971), and others concluded that the Kirkfield phase occupied both the Lake Michigan and Lake Huron basins.

The radiocarbon ages of the Cheboygan bryophyte bed constitute the only published evidence that indicates that the initial Kirkfield phase of Lake Algonquin did not enter the Lake Michigan basin and that the Straits of Mackinac were not deglaciated during the Twocreekan Substage. The reliability of the radiocarbon ages of the Cheboygan bryophyte bed is questioned in Supplementary Note 14. Although the bryophyte bed is shown as Mackinaw Interstadial in age on plate 1 (col. 2), in accordance with the interpretation of Farrand, Zahner, and Benninghoff (1969), I believe that the bed may be approximately the same age as the Two Creeks forest (Supplementary Note 14). Because all other published stratigraphic data from the Lake Michigan basin are compatible with an assumption that the Kirkfield phase occupied the Lake Michigan basin, the Kirkfield phase is shown to have occupied both the Lake Michigan and Lake Huron basins during the Twocreekan Substage (pl. 1, cols. $1,2)$.

\section{NOTE 12}

Radiocarbon ages of $11,500 \pm 180$ B.P. and $11,400 \pm 280$ B.P. (GSC-1429) (Harrison, 1972;

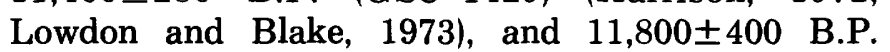
(GSC-1363) (Harrison, 1972) are too old in relation to other radiocarbon ages of the Algonquin and postAlgonquin lake succession. A grizzly-bear skull from
Lake Ardtrea sediments, dated $11,700 \pm 250$ B.P. (Geochron Laboratory, number not assigned) (Tovell and Deane; 1966; Harrison, 1972), also is too old in relation to other radiocarbon ages.

\section{NOTE 13}

Eastward drainage of Lake Wyebridge, by way of the South River outlet (Harrison, 1972), is tentatively correlated with formation of the Petawawa delta in the Champlain Sea, in the Ottawa River valley. Shells in marine sediments near Pembroke, Ontario, yielded an age of 10,870 \pm 130 B.P. (GSC-90). Although the shells do not have any necessary relationship to formation of the delta, deposition of the sediments near Pembroke and formation of the Petawawa delta are believed to have been contemporaneous (Harrison, 1972).

NOTE 14

Farrand, Zahner, and Benninghoff (1969), Farrand and Eschman (1974), and Evenson, Farrand, Eschman, Mickelson, Maher (1976) assigned a Cary-Port Huron (Mackinaw) interstadial age to the Cheboygan bryophyte bed in Michigan. They concluded that the till that overlies the bed represents continuous ice cover throughout the Port Huron stadial and the Two Creeks interstadial (the Straits of Mackinac were covered by ice throughout the Two Creeks interstadial). If that conclusion is accepted, the initial Kirkfield phase of Lake Algonquin could not have extended into the Lake Michigan basin during the Two Creeks interstadial (Supplementary Note 11).

The stratigraphy of the Cheboygan site and paleontologic data cited by Farrand, Zahner, and Benninghoff (1969) and Miller and Benninghoff (1969) are compatible with an alternative interpretation that the bryophyte bed is Two Creeks interstadial in age. If the Cheboygan bryophyte bed is Twocreekan in age, as inferred here, the till beneath the bed is equivalent to the "Port Huron" till elsewhere in Michigan, the till above the bed is equivalent to the Two Rivers Till in the Lake Michigan basin, the Straits of Mackinac may have been deglaciated during the Two Creeks interstadial, and the initial Kirkfield phase of Lake Algonquin may have occupied the Lake Michigan basin as well as the Lake Huron basin.

Assignment of a Cary-Port Huron (Mackinaw) interstadial age to the Cheboygan bed (Farrand and others, 1969) was based on an assumption that the older radiocarbon ages determined for the bryophytes (chiefly Scorpidium turgescens and Catascopium nigritum) are reliable and the younger ages are unreliable. Farrand and his colleagues accepted the 
ages of three radiocarbon samples: $13,300 \pm 400$ B.P. and $12,800 \pm 400$ B.P. (L-1064), $12,570 \pm 500$ B.P. (W-1889), and 12,500 \pm 500 B.P. (W-1847). Three other ages from a single sample from the same bed, reported by Crane and Griffin (1968), are $9,960 \pm 350$ B.P. (M-1753-1), $10,700 \pm 350$ B.P. (M-1753-2), and $10,700 \pm 350$ B.P. (M-1753-3). Sample M-1753-1 was rejected by Farrand, Zahner, and Benninghoff (1969) on the basis of a reasonable assumption that it is too young, but samples $\mathrm{M}-1753-2$ and $\mathrm{M}-1753-3$ were not mentioned.

Bryophytes (Drepanocladus fluitans) from near Castalia, Ohio, yielded radiocarbon ages 1,100-2,700 years too old (Sears, 1967; Ogden and Hay, 1967) (Supplementary Note 21). The Castalia samples may have been contaminated by fractionated inactive carbon (Ogden and Hay, 1967). It is possible that the oldest Cheboygan bryophyte ages also are unreliable, owing to fractionation, and that the age of the Cheboygan bed is approximately the same as the age of the Two Creeks forest $(11,850 \pm 100$ B.P.). Scorpidium turgescens, the most abundant moss species at the Cheboygan site, is a calcophile species (Miller and Benninghoff, 1969); it may incorporate inactive carbon by fractionation and may yield radiocarbon ages that are too old. The reliability of radiocarbon ages determined from different species of bryophytes has not been adequately tested.

In a discussion of the deglaciation history of Wisconsin and the Lake Michigan basin, Black $(1978$, p. 120) implied that the deglaciation history proposed by Evenson, Farrand, Eschman, Mickelson, and Maher (1976) is based on the inferred age of the Cheboygan bryophyte beds. Evenson, Farrand, Eschman, Mickelson, and Mayer $(1978$, p. 125$)$ replied that, “*** Black's indication that we based our conclusion only on evidence from the Cheboygan Bryophyte Bed locality is in error. There are a number of pertinent pieces of evidence other than the Cheboygan Bryophyte Bed; most of these were reviewed in the original bryophyte bed paper (Farrand and others, $1969)$ as well as in Dreimanis and Goldthwait (1973, p. 95) and Evenson and Dreimanis (1976, p. 219-220)." The paper by Farrand, Zahner, and Benninghoff (1969) contains discussion of four subjects: stratigraphy of the site, analysis of the bryophytes, radiocarbon age measurement, and stratigraphic interpretation. The site stratigraphy was compatible with an initial interpretation by the authors that the moss horizon was the same age as the Two Creeks buried forest; revision of the stratigraphic history of the site was mandated by acceptance of the oldest radiocarbon ages of the moss, not by the stratigraphy of the site. Analysis of the bryophytes provided no information relevant to the age of the moss or the deglaciation history. The pollen analytical data were inconclusive, as discussed below. The deglaciation history of the entire Lake Michigan basin was inferred from the deglaciation history of the site, in turn directly related to the inferred radiocarbon age of the moss horizon. The synthesis by Dreimanis and Goldthwait (1973) contained only references to the interpretations and conclusions of Farrand, Zahner, and Benninghoff (1969) and Miller and Benninghoff (1969); no specific evidence in support of the deglaciation history outlined by Evenson, Farrand, Eschman, Mickelson, and Maher (1976) was discussed. Likewise, the summary by Evenson and Dreimanis (1976) contained no discussion of evidence.

Farrand, Zahner, and Benninghoff $(1969$, p. 256) implied that seven samples from the $1-\mathrm{cm}$ thick moss horizon were analyzed for pollen. According to Miller and Benninghoff $(1969$, p. 238), however, only two of the samples were from the moss horizon. The other five samples were from one horizon in the underlying sand and two horizons in the overlying lake sediments. Farrand, Zahner, and Benninghoff (1969, p. 256) emphasized the dissimilarity of the pollen spectra of the Cheboygan bryophyte bed and the Two Creeks forest bed. At the same time, however, they noted a similarity between the spectra of the moss bed and the lower part of C. E. Schweger's pollen diagram from the Duck Creek Ridge site, southwest of Green Bay, Wis. (Black and others, 1965). The latter section has been correlated with the Two Creeks buried forest (Black and others, 1965; Farrand and others, 1969; Schweger, 1969; Maher, 1970). Wood from the Duck Creek site yielded a radiocarbon age of $11,640 \pm 350$ B.P. (Maher, 1970 , p. D5). The pollen diagram of Miller and Benninghoff (1969, fig. 1) indicated that in the Cheboygan moss horizon the arboreal pollen was dominated by spruce and the nonarboreal pollen was dominated by sedges, with arboreal pollen subordinate to nonarboreal pollen. In the lower half of the Duck Creek Ridge pollen diagram (Black and others, 1965, fig. 8-2) the same relationship was evident. I am more impressed by the similarity of the pollen spectra of the Cheboygan and Duck Creek sites than by the dissimilarities of the spectra of the Cheboygan and Two Creeks sites. The dissimilarities of the spectra of the latter two sites were inferred to indicate that the Cheboygan bed is older than the Two Creeks buried forest (Farrand and others, 1969, p. 256-257). Following the same reasoning, the similarity of the pollen spectra from the Cheboygan and Duck Creek Ridge sites may be inferred to indicate that the Cheboygan bed is the same age as (or even slightly younger than) the Two Creeks buried forest. 
Comparison of pollen percentages from the Cheboygan bed in Michigan with percentages from sites in Wisconsin may not be a reliable means of determining whether organic deposits at the respective sites were contemporaneous. Black, Hole, Maher, and Freeman $(1965$, p. 70$)$ concluded that, “***enough unknown factors exist in the pollen data to make any firm conclusions about the climate of the Two Creeks interval premature* **," and Evenson, Farrand, Eschman, Mickelson, and Maher (1976, p. 421) noted that “***in the Lake Michigan basin it may be impossible to distinguish response of vegetation to a change in regional climate from a response caused by expanding proglacial lakes and the presence of wasting Two Rivers ice."

In view of (1) the uncertain reliability of correlation by means of pollen spectra, (2) the 3,700-year range of measured ages of the Cheboygan bed, (3) the age discrepancies in dating the Castalia bryophytes, and (4) the possibility of isotope fractionation in some species of bryophytes, the age and the correlation of the Cheboygan bed are considered unproved. Resolution of the age of the bed is extremely important because the deglaciation history in the Lake Michigan and Lake Huron basins is dependent upon assignment of a correct age to the bryophyte bed (Supplementary Note 1).

NOTE 15

Correlation of specific moraines of the LansingGrand Ledge-Ionia-Portland-Lyons-Fowler moraine succession in Michigan with the Arva, Milverton, Mitchell, Dublin, and Lucan moraines in Ontario has not been demonstrated on the basis of till stratigraphy. The correlations shown are speculations.

Farrand and Eschman (1974) suggested that outwash surfaces that head at the Portland, Fowler, and Flint moraines can be projected through the Grand Valley to the Allendale delta and that all three surfaces are graded to the Glenwood level of Lake Chicago. The Allendale delta is younger than the Lake Border moraines of the Lake Michigan lobe in Michigan; hence, the Portland moraine is younger than the Lake Border moraines. Initiation of Lake Maumee II drainage through the Grand Valley to the Glenwood phase of Lake Chicago, by way of Early Lake Saginaw, occurred when the Saginaw lobe ice margin retreated from the Fowler moraine (Bretz, 1953).

NOTE 16

Correlation of the Arva, Milverton, Mitchell, Dublin, Lucan, Seaforth, and Centralia moraines in the Huron lobe area of Ontario with specific moraines of the Ingersoll-Blenheim-St. Thomas-Norwich-Tillsonburg moraine succession in the Erie lobe area of Ontario has not been demonstrated on the basis of till stratigraphy. The correlations shown are speculations (see Supplementary Note 24).

\section{NOTE 17}

Correlation of specific moraines in the Michigan lobe and Saginaw sublobe areas in southern Michigan with specific moraines in the Huron and Erie lobe areas in southeastern Michigan has not been demonstrated on the basis of till stratigraphy. The correlations shown are speculations, based on assumptions that the Redfield-Three Rivers and Tekonsha moraines are approximately the same age as the Union City moraine, and the Inner Valparaiso moraine is approximately the same age as the Wabash moraine (Zumberge, 1960; Wayne and Zumberge, 1965). (See Supplementary Notes 18 and 19.)

\section{NOTE 18}

The southern limit of glaciation in south-central Michigan and north-central Indiana, contemporaneous with formation of the Union City moraine, has not been established on the basis of till stratigraphy. On the basis of the areal distribution of deposits and meltwater channels of the "Kankakee flood" (Zumberge, 1960; Wayne and Zumberge, 1965), the Redfield-Three Rivers and Tekonsha moraines here are regarded to be correlatives of the Union City moraine (Supplementary Note 9).

NOTE 19

The southern boundary of the New Holland Till Member of the Lagro Formation (Wayne, 1963) coincides with the distal margin of the Union City moraine in northeastern Indiana (Wayne, 1968; Gooding, 1971). The New Holland Till Member was deposited during the Port Bruce stadial, following ice-margin recession into (or, more probably, north of) the Lake Erie basin during the Mackinaw interstadial. Esker alinement and thin till over ice-contact deposits and outwash in the Packerton moraine complex in Miami, Wabash, Kosciusko, and Noble Counties, Ind. (Wayne and Thornbury, 1951; Thornbury and Deane, 1955; Zumberge, 1960; Wayne and Zumberge, 1965), indicate that parts of the Packerton moraine were formed by Huron lobe ice (fig. 2) during the Port Bruce stadial and that other parts of the moraine consist of older 
drift that was overridden by Huron lobe ice during the stadial. Thin till over outwash in the Ann Arbor and Northville areas, Michigan (Dorr and Eschman, 1970), also probably is the New Holland Till Member.

NOTE 20

Fluctuations of ice margins of the Huron lobe and Georgian Bay and Lake Simcoe sublobes (fig. 2) produced a number of distinct till sheets that overlap one another in southern Ontario (Karrow, 1974a; Cowan and others, 1975; Cooper and others, 1977). The spatial and temporal relationships of these tills cannot be shown adequately on the columns of the chart. The correlations assigned here are tentative. The Bogarttown, Elma, Kettleby, Mornington, Newmarket, Rannoch, St. Joseph, Stirton, Stratford, Tavistock, and Wartburg tills, and other unnamed tills of the Huron and Georgian Bay lobes, all were deposited during the Port Bruce stadial. (See reports by G. J. Burwasser, A. J. Cooper, W. R. Cowan, B. H. Feenstra, Q. H. J. Gwyn, P. F. Karrow, D. R. Sharpe, U. J. Vagners, and A. Dreimanis and A. V. Morgan.)

NOTE 21

Bryophytes (Drepanocladus fluitans) from near Castalia, Ohio, yielded four radiocarbon ages: $13,911 \pm 418$ B.P. (OWU-168), 13,530 4420 B.P. and $15,530 \pm 420$ B.P. (OWU-168-A), and $14,790 \pm 420$ B.P. (OWU-168-B) (Sears, 1967; Ogden and Hay, 1967). Growth of the moss occurred after formation of Lake Lundy in the Lake Erie basin; hence, the samples should provide minimum ages of extinction of Lake Grassmere. The estimated age of Lake Lundy is 12,400 B.P. (pl. 1), and the radiocarbon ages are at least $1,100-2,700$ years too old (at least $700-3,500$ years too old if ranges of statistical errors are considered). Sample OWU-168-B is a rerun of sample OWU-168-A, and it received additional pretreatment to insure complete removal of shell and marl carbonate; the sample was "carbonate-free" (Ogden and Hay, 1967). Removal of carbonate by pretreatment does not preclude incorporation of Paleozoic limestone into the living mosses, and at least part of the age anomaly may be a result of isotopic fractionation by the mosses. (See Supplementary Note 14.)

\section{NOTE 22}

The limit of the Halton Till (Karrow, 1963) has been revised as a result of recent studies north of Lake Erie (Feenstra, 1972, 1973, 1974) and west and northwest of Toronto (Karrow, 1970; White, 1975; Gwyn, 1975c).
The boundary north of Lake Erie is just east of Caledonia and Cayuga, Ontario, 8-10 km west of Port Maitland and Dunnville, and it intersects the present Lake Erie shore at Point Evans, Ontario (Feenstra, 1973). The configuration of the revised Halton Till limit in Ontario supports a correlation of the Halton glacial advance and an advance in New York to the position of the Alden moraine (Supplementary Note 32).

NOTE 23

The history of Lake Maumee outlined in publications by Frank Leverett, F. B. Taylor, and Frank Carney was generally accepted in syntheses by Flint (1947, $1953,1957,1971)$, Hough (1953, 1958, 1963, 1966, 1968), Wayne and Zumberge (1965), Kelley and Farrand (1967), Dorr and Eschman (1970), Eschman and Farrand (1970), and Prest (1970). The succession of water levels (Maumee I, $800 \mathrm{ft}$; Maumee II, $760 \mathrm{ft}$; Maumee III, $780 \mathrm{ft}$ ) was questioned by Bleuer and Moore (1972a, 1972b). Leverett (1939) inferred that the $760-\mathrm{ft}$ level was reoccupied prior to extinction of Lake Maumee, and stratigraphic evidence in Ohio and $\mathrm{On}$ tario is compatible with the concept of a brief Maumee IV phase at $760 \mathrm{ft}$. The succession of water levels inferred in the Fort Wayne area, Indiana, by Bleuer and Moore $(800 \mathrm{ft}-780 \mathrm{ft}-760 \mathrm{ft})$, may relate to the Maumee I-Maumee III-Maumee IV succession, rather than the Maumee I-Maumee II-Maumee III succession. It is possible that Maumee I (800 ft) drained by way of the Fort Wayne outlet, Maumee II $(760 \mathrm{ft}$ ) drained by way of a channel north of the Flint moraine (obliterated by the later readvance to the Flint moraine), Maumee III (780 ft) drained first by way of the Imlay outlet and later by way of the Fort Wayne outlet (owing to differential uplift of the Imlay outlet), and Maumee IV $(760 \mathrm{ft})$ drained by way of the Fort Wayne outlet.

Radiocarbon sample I-4899 (13,770 \pm 210 B.P.) was attributed to deposition during the existence of Lake Maumee III by W. R. Farrand (comment in Buckley and Willis, 1972). Farrand and Eschman (1974) cited the work of Burgis (1970) and concluded that the sample postdates extinction of Maumee III.

NOTE 24

The relationship of the Ingersoll, Blenheim, St. Thomas, Norwich, Tillsonburg, and Sparta moraines, in southern Ontario, to the Defiance, Brooklyn, Euclid, Painesville, and Ashtabula moraines, in Ohio, has not been demonstrated on the basis of till stratigraphy. The Ingersoll moraine is overlapped by the Arva 
moraine in the Huron lobe area; the Arva moraine and the younger Mitchell moraine both were formed prior to extinction of Lake Maumee II (but not necessarily during the existence of Maumee II). The Ingersoll moraine is not linked stratigraphically to a specific Lake Maumee phase and it may have been formed during the existence of Lake Maumee I. It may be the same age as the Definance moraine in Ohio, or it may be younger. The Blenheim moraine was submerged in Lake Maumee, but it is not linked to a specific lake phase. Dreimanis $(1963,1969 \mathrm{~b})$ concluded that the double-crested St. Thomas moraine was formed shortly prior to extinction of Lake Maumee II, but published stratigraphic evidence is not conclusive. The glacial readvance that was initiated during the existence of latest Lake Maumee II (Dreimanis and Karrow, 1965) here is considered to have been responsible for deposition of the Ashtabula Till in Ohio, and is considered to have been synchronous with the advance responsible for formation of the Flint moraine in Michigan. Culmination of the Flint advance was responsible for the rise from the Maumee II level to the Maumee III level in the Lake Erie basin (Bretz, 1951a, 1953). The St. Thomas moraine in Ontario and the Painesville moraine in Ohio both were formed as a result of the readvance in the Lake Erie basin, and on the correlation chart it is inferred that they were formed shortly after the Maumee II-Maumee III transition, contemporaneously with the Flint moraine. Neither the St. Thomas moraine nor the Painesville moraine necessarily coincides with the maximum extent of the glacial readvance. Lake Maumee III sediments overlie the younger Sparta (equal to Tillsonburg) moraine, indicating that the Norwich, Tillsonburg, and Sparta moraines were formed during the existence of Lake Maumee III. Correlation of the Ashtabula moraine with Lake Arkona (Coates, 1976) is not supported by stratigraphic data from Ohio and Pennsylvania. Strand features on and north of the Ashtabula moraine indicate that the moraine was formed prior to extinction of Lake Maumee.

\section{NOTE 25}

The Brooklyn (Cleveland) moraine of Leverett (1902b, 1931b) and Carney (1913b), composed in part of Lavery Till and in part of Hiram Till, is morphostratigraphically equivalent to the complex Euclid moraine. Thick deposits of Hiram Till on the proximal side of the Euclid moraine overlie an older end-moraine core of Lavery Till. The massive Euclid moraine terminates west of the Chagrin River in Ohio. Narrow segments of end moraine east of the river are continua- tions of a younger (post-Euclid) moraine that is banked against the north edge of the Euclid moraine at the Cuyahoga-Lake County boundary, northeast of Cleveland. The latter moraine and the segments of end moraine east of the Chagrin River are composed of Ashtabula Till. The type Euclid moraine is not composed of Ashtabula Till.

The Defiance moraine on the rolling till plain in northwestern and north-central Ohio is a fairly continuous belt of moraine $1-8 \mathrm{~km}$ wide. The massive moraine terminates in southwestern Medina County, Ohio, as inferred by Leverett $(1902 \mathrm{~b}$, pls. 2, 13). Eastward from Lodi, Ohio, the ice margin entered more dissected terrain and then rose onto the Allegheny Escarpment. The integrity of the moraine is lost in the more rugged topography in eastern Medina, Summit, and Cuyahoga Counties. There, two to more than ten narrow, arcuate end moraines intersect or cross the major valleys, and discontinuous segments of lateral moraines of ice tongues in the valleys rise onto the valley walls. Parts of the valley walls and some interfluves are marked by areas of kames and discontinuous belts of constructional till topography, interrupted by extensive areas of thin ground moraine and exposed bedrock. Specific moraine loops in the valleys cannot be traced from valley to valley with certainty. Carney (1913b; and unpublished maps on file at the Ohio Geological Survey, Columbus, Ohio) concluded that the Northfield moraine, in Summit and Cuyahoga Counties, is younger than the Defiance moraine west of Lodi. Leverett (1931b) revised his earlier (1902b) interpretations; he mapped the Northfield moraine as a continuation of the Defiance moraine and traced what he considered to be the Defiance moraine eastward to Pennsylvania. The broad belt of drift mapped as a moraine by Leverett (1931b) from Lodi, Ohio, to Pennsylvania is a complex, topographically controlled system of moraine segments and other deposits of several different ages, representing several pulsations of ice margins; it does not represent a single glacial advance or stillstand of an ice margin. Retention of the name "Defiance moraine" for the system of moraine segments is misleading. White (1953a, 1953b, 1977; in Winslow and White, 1966) accepted Leverett's (1931b) interpretations and mapped the "Defiance moraine" in the Grand River sublobe in northeastern Ohio. Shepps, White, Droste, and Sitler (1959) and Muller (1956, 1963) continued tracing of Leverett's "Defiance moraine" through Pennsylvania to southwestern New York. There is no assurance that any part of the drift belt in the Grand River sublobe in Ohio and in the Erie lobe in Pennsylvania and New York is the same age as the type Defiance moraine in northwestern Ohio. 
NOTE 26

The distal margin of the Powell moraine, in the Scioto sublobe in Ohio, is the southern boundary of a distinctive till sheet (Forsyth, 1956a, 1965, 1967; Goldthwait and others, 1961, 1965; Steiger and Holowaychuk, 1971; Dreimanis and Goldthwait, 1973; Goldthwait, 1976). Although the Powell moraine consists of at least four moraine ridges in places and the outermost ridge in some areas is overlapped by or buried by younger ridges in other areas, all the ridges are composed of lithologically and texturally similar till (Supplementary Note 27).

The Powell moraine (Leverett, 1902b) was traced northeastward from its type area in Union and Delaware Counties, Ohio, by White $(1935,1939)$. Totten $(1962,1969,1973)$ accepted White's conclusion that the moraine trends northeastward from a position east of Mt. Gilead to Blooming Grove, and then into Richland County, Ohio. White (1967) concluded that the southern limit of the Hiram Till in Wayne County coincides with the distal margin of the Wabash moraine, and in his figure 1 he indicated that the till limit also coincides with the distal margin of the Wabash moraine in Ashland and Richland counties, as shown on the "Glacial Map of Ohio" (Goldthwait, White, and Forsyth, 1961). Totten (1973) suggested that the Hiram Till boundary in Richland County is far south of the Wabash moraine and that the "Powell moraine" of White $(1935,1939)$ is composed of Hiram Till. Consequently, Totten concluded that the till that composes the Powell moraine in the central part of the Scioto sublobe also is the Hiram Till.

The "Powell" ice-margin position does not continue northward from Mt. Gilead; it trends northeastward to Shauck, loops into the Cedar Fork valley in Morrow County, loops southeast of Kings Corners in Richland County, and then loops southeastward in the valley of Clear Fork Mohican River to merge with the Hayesville Till boundary at Lexington. The southern boundary of the till that comprises the Powell moraine and the younger Broadway moraine in the type area of the moraines in central Ohio coincides with the "Centerburg" till and Hayesville Till boundaries south and southeast of Clear Fork Reservoir, in Richland County, Ohio, as shown on plate 1 of Totten (1973). The Hiram Till boundary in the central part of the Scioto sublobe is north of the Broadway moraine, and in western Ohio and eastern Indiana it probably coincides with the distal margin of the Wabash moraine (Goldthwait, 1958, 1959; Goldthwait and others, 1961; Steiger and Holowaychuk, 1971; Gooding, 1971).
NOTE 27

The complex Powell moraine in many places is a product of two significant glacial readvances. Each readvance was represented by several minor pulsations of the ice margin. Part of the buried Bokes Creek moraine (Forsyth, 1956a, 1956b) and part of the Powell moraine were formed at the culmination of the initial Port Bruce stadial glacial readvance. The ice margin receded more than $15 \mathrm{~km}$ (perhaps several tens of kilometers) and then readvanced, overriding the earlier formed part of the Bokes Creek moraine and parts of the earlier formed Powell moraine. In places the outermost ridge of the present Powell moraine was formed as a result of the early advance and in other places the outermost ridge was formed as a result of the later advance. The Broadway moraine was formed as a recessional moraine during dissipation of the Powell ice. As a result of the two-phase origin of the Powell moraine, the moraine consists of one to four imbricated ridges, and in many places it consists of two nearly identical, superposed till units. The till that comprises the Powell and Broadway moraines in the Scioto lobe has not been named, and it is referred to informally as the "Powell" till for purposes of discussion. The "Powell" till of the moraine and the older "Darby" till (Dreimanis and Goldthwait, 1973; Goldthwait, 1976) south of the moraine are distinctly different in texture, color, and other properties. In many places in and north of the Powell moraine the unoxidized "Powell" and "Darby" tills are separated by a leached, oxidized horizon or by a boulder pavement, colluvium, lake sediments, outwash, and (or) flood-plain alluvium. The two "Powell" till units locally are separated by a boulder pavement, colluvium, outwash, and (or) lake sediments.

The "Powell" till is lithostratigraphically equivalent to the Hayesville Till in the Killbuck sublobe (Supplementary Note 26). The Hayesville Till also is composed of two till units in many exposures in Wayne and Stark Counties, Ohio.

\section{NOTE 28}

Radiocarbon sample OWU-83 $(14,780 \pm 192$ B.P.) was wood from till north of the Powell moraine. Because the measured age was younger than ages of other wood samples from till in central Ohio, Ogden and Hay (1965) inferred that the wood was slumped into the till; hence, the wood postdates deposition of the till. The wood was recovered at a depth of nearly 3 $m$ in the till (Ogden and Hay, 1965), and it is unlikely that it was buried as a result of postglacial slumping. 
If the age is reliable the wood may provide an approximate age of the interval represented by a boulder pavement, colluvium, outwash, and (or) lake sediments between the two "Powell" till sheets in and north of the Powell moraine (Supplementary Note 27). If so, the sample provides a minimum age for the lower "Powell" till sheet and a maximum age for the upper "Powell" till sheet. It is also possible that the sample is too young, owing to contamination, and that the wood is of Erie interstadial age.

NOTE 29

Dreimanis (1967b, 1969a) and Mörner and Dreimanis $(1970,1973)$ assumed that Lake Leverett, in the Lake Erie basin, drained eastward through the Mohawk Lowland during the Erie interstadial, and subsequent authors have not questioned the drainage history. Many of the buried Erie interstadial beaches and deltas in the London and Sparta areas, Ontario, are at altitudes similar to present measured or projected altitudes of Lake Maumee I and Lake Maumee II strands, or no more than $5 \mathrm{~m}$ below the projected level of Lake Warren I. Lakes Maumee I, Maumee II, and Warren I drained westward, and all the latter Lake Leverett strands and deltas could have been formed in waters that also drained westward.

The type locality for the Erie interstadial is the site of a buried Lake Leverett beach that is less than $4 \mathrm{~m}$ above present Lake Erie and less than $45 \mathrm{~m}$ below the projected level of Lake Warren I (Mörner and Dreimanis, 1973). Mörner and Dreimanis (1973, p. 118) concluded, "If the Erie Interstade lake level at the type section is extrapolated as a shoreline parallel to the Lake Warren shoreline, it falls at a level $9 \mathrm{~m} \mathrm{(30} \mathrm{ft)}$ below the present Lake Erie level in the area of horizontal shorelines at the southwestern end of Lake Erie." On the basis of this extrapolation, they concluded that Lake Leverett drained eastward to the Hudson Lowland.

There is no reason to suspect that the configuration of isobases reconstructed from buried Lake Leverett strands has any consistent relationship to the configuration of isobases of Lake Warren. The areal distribution and altitudes of Lake Leverett strands are related to the configurations and thicknesses of ice lobes during dissipation of Nissouri stadial ice in Indiana, Michigan, Ohio, Pennsylvania, and Ontario. Differential uplift of the Lake Erie Basin during the existence of the lake, subsequent crustal depression of the basin by ice lobes of different configurations and thicknesses during the Port Bruce stadial, differential uplift of the basin during the Mackinaw interstadial, and probable crustal readjustment during the early part of the Port Huron Stadial, all contributed to the present areal distribution and altitudes of Lake Warren strands. (See Supplementary Note 37.)

\section{NOTE 30}

Y-691 (listed as Y-391 in several publications) was wood from approximately $12 \mathrm{~m}$ below the crest of a Lewiston phase Lake Iroquois beach or bar (Karrow and others, 1961; Stuiver, 1969). The sample antedates the Lewiston phase and relates to the earliest and lowest (Newfane) phase of Lake Iroquois that elsewhere in the Lake Ontario basin is inferred to have been $12 \mathrm{~m}$ lower than the Lewiston phase (Kindle and Taylor, 1913). The radiocarbon age is younger than the three Lewiston phase ages (W-861, I-838, and W-883); however, it is unreliable and should be considered only a minimum age of the Newfane phase.

NOTE 31

Muller (1975) suggested that dissipation of ice north of Batavia, N.Y., resulted in expansion of Lake Warren (Warren II on pl. 1) into central New York and subsequent eastward drainage of Great Lakes waters by way of the Syracuse channels. The confluent, eastward-draining waters correspond to Lake Wayne in the Lake Erie basin and the "Falling Vanuxem" or "Lowering Vanuxem I" waters (of H. L. Fairchild, 1932a) in the Finger Lakes region. Muller also suggested that a subsequent glacial readvance caused renewal of Lake Warren (Warren III on pl. 1) in the Lake Erie basin and reinstated westward drainage of waters in central New York. Lake Warren III was contemporaneous with lake "Warren" (of H. L. Fairchild, 1932a) in central New York, and the rise of waters to both levels was caused by a major glacial readvance in the Lake Ontario basin. The Syracuse channels must have been covered by the readvanced ice margin in order for westward drainage of waters in central New York to have occurred.

Calkin (1970) concluded that the Batavia moraine was formed shortly prior to the transition from Lake Warren III to Lake Grassmere. Muller (1975) implied that the Batavia moraine was formed at the culmination of the glacial readvance that caused the rise to the Warren III level. I accept Calkin's interpretation and Muller's (written commun., 1977) more recent interpretation that the Batavia moraine was formed very shortly prior to inception of Lake Grassmere. The Alden moraine was formed as a result of the readvance that caused the rise to the Lake Warren III level in the Lake Erie basin; thus, the Batavia moraine was formed as a result of a minor readvance shortly prior to extinc- 
tion of Lake Warren III. (See Supplementary Note 32.)

Calkin (1970) concluded that the Hamburg moraine was formed shortly prior to the transition from Lake Whittlesey to Lake Warren I and that the Marilla moraine was formed in Lake Warren I. E. H. Muller (written commun., 1977) cited stratigraphic evidence that suggests that the Marilla moraine was formed in Lake Whittlesey shortly prior to inception of Lake Warren I.

NOTE 32

The glacial readvance responsible for deposition of the Halton Till in Ontario occurred after extinction of Lake Warren I (Karrow, 1963). A low-lake phase occupied the Lake Erie basin and the southwestern end of the Lake Ontario basin at the time of initial readvance of the ice margin. The readvance was accompanied by a rise of water in the Lake Erie basin to a renewed Lake Warren level. Only one well-developed Lake Warren strand was observed on the Halton Till, and Karrow (1963) assumed that the readvance was contemporaneous with a rise to the Lake Warren II level. Calkin $(1968,1970)$ concluded that the Warren II phase was brief and was a lowered phase, however, that Lake Warren II strands are poorly developed, and that Lake Warren III strands are the best developed of all Lake Warren strands in western New York. The stratigraphic data cited by Karrow (1963) are compatible with conclusions that (a) the Halton advance occurred after extinction of Lake Warren II and after Lake Wayne was established in the Lake Erie basin, (b) the advance was contemporaneous with the rise to the Lake Warren III level, and (c) the well-developed strands on the Halton Till were formed by Lake Warren III, rather than Lake Warren II.

The Halton Till boundary extends from west of Hamilton, Ontario (Karrow, 1963), south to the Lake Erie shore at Point Evans (Feenstra, 1973; Supplementary Note 22). The southern (or western) limit of the till in much of southern Ontario is not marked by conspicuous end moraines. The submerged Port Maitland moraine in Lake Erie, an eroded segment of end moraine at Mohawk Point, and the Crystal Beach, Fort Erie, Niagara Falls, and Vinemount moraines on the Niagara Peninsula are composed of or are veneered by Halton Till (Feenstra, 1972, 1973, 1974). The location of the Halton Till boundary on the floor of Lake Erie is not known, but the bathymetry of the basin (Sly and Lewis, 1972, fig. 12) favors a hypothesis that it trends eastward from Point Evans, coincides with the south margin of the submerged Port Maitland moraine, and continues eastward to the New York shore south of Buffalo.
The Alden moraine, south of Buffalo, N.Y., was attributed to a glacial readvance by Kindle and Taylor (1913) and Leverett and Taylor (1915). The moraine has been correlated with several different moraines in Ontario. (See discussion by Taylor, 1939, p. 385-387.) P. E. Calkin (written commun., 1975) reported stratigraphic evidence of a glacial readvance from north of the position of the Buffalo moraine south almost to the Alden moraine. E. H. Muller (written commun., 1977) reported that a readvance from Clarendon, N.Y., south nearly to the Alden moraine is documented in a series of exposures in gravel pits and that the configuration of Lake Warren I spits across the Marilla moraine indicates that significant icemargin recession north of the present position of the Alden moraine occurred prior to formation of the Alden moraine. Muller tentatively correlated the Alden moraine with the Fort Erie moraine in Ontario, however, and suggested that the limit of the Halton readvance in New York is south of the Alden moraine.

The till boundary in New York that is equivalent to the Halton Till boundary in Ontario cannot be far south of the Alden moraine because well-developed strands of Lakes Warren I and Warren II terminate $3.2 \mathrm{~km}$ south of the moraine (Leverett, 1902b; Fairchild, 1907c; Kindle and Taylor, 1913; Leverett and Taylor, 1915; Calkin, 1968, 1970). Extinction of Lake Warren I antedated the Halton advance in Ontario (regardless of the correlation of strands on the Halton Till); hence, the equivalent till boundary in New York must be north of the termination of Lake Warren I strands.

The abrupt termination of Lakes Warren I and Warren II strands south of the Alden moraine, stratigraphic evidence of a significant glacial readvance to or nearly to the position of the moraine, and alinement of the moraine with the expected configuration of the Halton Till boundary on the floor of Lake Erie all suggest that the Alden moraine marks the approximate southern limit of the "Halton" readvance in New York. The southern limit of the till may be south of the moraine, at or near the locations of termination of Lakes Warren I and Warren II strands. Strands of Lakes Warren I and Warren II probably were formed north of the position of the moraine but were overridden by ice or were destroyed by melt water at the time of the readvance.

The Wentworth Till in Ontario was deposited as a result of an early Port Huron Stadial glacial readvance contemporaneous with the rise of waters in the Lake Erie basin to the Lake Whittlesey level (Karrow, 1963; Dreimanis and Karrow, 1965; Goldthwait, Dreimanis, Forsyth, Karrow, and White, 1965; Terasmae, Karrow, and Dreimanis, 1972; Sly and Lewis, 1972). The Paris 
moraine is the oldest end moraine composed of Wentworth Till north of present Lake Erie, although the till boundairy is not everywhere marked by end-moraine topography. Strands of Lakes Maumee and Arkona terminate abruptly south (or west) of the Wentworth Till boundary, owing to overriding of Lake Maumee and Arkona sediments by the Wentworth ice.

The Wentworth Till boundary and the Paris moraine north of the Lake Erie shore are alined with the submerged Norfolk (Long Point-Erie) moraine in Lake Erie (Wall, 1968; Sly and Lewis, 1972). The latter moraine also was formed as a result of the early Port Huron readvance, contemporaneous with the rise to the Lake Whittlesey level (Wall, 1968; Sly and Lewis, 1972). The configuration of the submerged moraine and the bathymetry of the lake basin (Sly and Lewis, 1972, fig. 12) are such that the ice margin is expected to have intersected the south shore of present Lake Erie in the vicinity of Girard, Pa.

Leverett (1902b) observed that beaches of Lake Maumee terminate abruptly south of the Girard moraine in Pennsylvania, and that Lake Whittlesey beaches continue northward onto and north of the moraine. He assumed that Lake Maumee was lowered directly to the Lake Whittlesey level; consequently, he assumed that the ice margin stood at the position of the Girard moraine at the time of the MaumeeWhittlesey transition. Subsequent work by Taylor (1905) and others demonstrated that Lake Maumee was lowered to the Lake Arkona levels and that the still-later rise to the Lake Whittlesey level was caused by a significant glacial readvance. Taylor (in Leverett and Taylor, 1915, p. 373-376, pl. XVIII) mistakenly mapped Arkona strands on and north of the Girard moraine in Pennsylvania and New York. As Taylor (1939) and Leverett (1939) later emphasized, the Arkona strands mapped in 1915 are the Lake Warren I strands of Leverett (1902b) and Fairchild (1907c). Evans (1970) and [Evans] Schooler (1974) confirmed the termination of Lake Maumee III strands south of the Girard moraine. She identified two lower strands of Lake Arkona and noted that they also terminate south of the moraine. Schooler $(1974$, p. 9) inferred that the Girard moraine was formed as a result of a glacial readvance, but she cited Leverett and Taylor (1915) and Hough (1958) as sources of a conclusion that the moraine was formed prior to extinction of Lake Maumee III. As mapped by Schooler (1974, pl. 1), the Maumee III beach terminates less than $2.25 \mathrm{~km}$ southwest of the Girard moraine. If the beach and the moraine were formed simultaneously, the ice margin was less than $1.5 \mathrm{~km}$ west of the beach and the beach was formed in a long, narrow arm of Lake Maumee between the ice margin and high ground to the east. The
Maumee III beach at its northward termination is relatively well developed (Leverett, 1902b; Leverett and Taylor, 1915; Evans, 1970; Schooler, 1974). The development of the beach suggests that it was formed in open water with appreciable fetch, far from an ice margin. If this reasoning is valid, the beach was formed in Lake Maumee III before the Girard moraine was formed and at a time when the ice margin was far north of Girard, Pa.

Termination of Lakes Maumee III and Arkona strands south of the Girard moraine was observed by Leverett and Taylor (1915), Evans (1970), and Schooler (1974), but the significance of termination of strands of both lakes at the same place was not evaluated. If the Girard moraine formed in Lake Maumee III immediately prior to the Maumee III-Arkona transition, Maumee III strands are expected to terminate at or south of the moraine, but Arkona I, Arkona II, and Arkona III strands are expected to be present on and north of the moraine. Two Arkona strands terminate south of the moraine (Schooler, 1974, pl. 1), but no strands correlative with the Arkona strands south of the moraine and in Ohio have been identified on or north of the Girard moraine. (As noted previously, the Arkona strands of Leverett and Taylor (1915) are Lake Warren I strands.) Abrupt termination of strands of Lakes Maumee III and Arkona near Girard is analogous to the termination of the same strands at or near the southern (or western) limit of the Wentworth Till in Ontario. The readvance responsible for formation of the Girard moraine occurred after extinction of Lakes Maumee and Arkona. Strands of both lakes probably were formed farther north in Pennsylvania (and perhaps in New York); the latter strands were obliterated as a result of the readvance to the position of the Girard moraine.

The observation that the Girard moraine was formed as a result of a glacial readvance (Schooler, 1974), the abrupt termination of Maumee III and Arkona strands south of the moraine, and the striking alinement of the Wentworth Till boundary in Ontario, the submerged Norfolk moraine in Lake Erie, and the Girard moraine in Pennsylvania all support a conclusion that the Girard moraine was formed as a result of the early Port Huron Stadial readvance in the Lake Erie basin, contemporaneous with the rise to the Lake Whittlesey level.

NOTE 33

The Leaside Till of the Ontario lobe in Ontario was defined as a formal rock-stratigraphic unit (Karrow, $1967 \mathrm{~b}, 1968 \mathrm{~b}, 1969 \mathrm{~b})$. The upper unit of the Leaside Till subsequently was shown to be equivalent to the 
Halton Till (Karrow, 1963) in the Hamilton region, Ontario (Karrow, 1974a). The name Halton has priority; and, consequently, Karrow (1974a) proposed that the name Leaside Till be removed from formal rockstratigraphic nomenclature.

\section{NOTE 34}

Formation of the Dummer moraine was approximately synchronous with southwestward movement of ice of the "Upper Rideau-Newboro Lakes lobe," west of Brockville, Ontario (Henderson, 1973a). A postulated glacial readvance in the vicinity of Prescott, Ontario, northeast of Brockville (Terasmae, 1965), postdated formation of the Dummer moraine. Evidence of transgression of the Champlain Sea in the vicinity of Prescott prior to the postulated advance has not been cited. Moraine ridges in the vicinity of Stittville, Bells Corners, Gloucester, and Bowesville, south of Ottawa (Johnston, 1917; Gadd, 1961, 1963), continue at least as far south as Kemptville, Ontario (Reinecke, 1917; Hills and others, 1944), and the alinement favors correlation of the moraines with the postulated readvance near Prescott. Ice occupied the lower Gatineau and Ottawa River valleys at the time of formation of the moraines, and the ice margin probably crossed the Ottawa River valley between Shirleys Bay and Queens Park (Gadd, 1961, 1963). The OttawaAlexandria area, Ontario, is inferred to have been covered by ice at the time of formation of the moraines (Gadd, 1961).

Marine shells in till-like diamictons at a number of localities in Ontario and Quebec, east and southeast of Ottawa, have been cited as evidence of a glacial readvance into the Champlain Sea (Richard, 1975a, 1975b, 1976, 1977). Evidence of a readvance in other regions that presumably also were covered by the ice of the proposed "Newington readvance" has not been observed, however (Gwyn and Lohse, 1973; Gwyn and Thibault, 1974), and borings in the Ottawa River valley provided no evidence of a readvance into the Champlain Sea (Gadd, 1977). Harrison (1977) questioned the glacial origin of the shell-bearing deposits and suggested that the diamicton may be a marine sediment that was deposited by coastal processes in the Champlain Sea.

A shell-bearing till-like diamicton in oriented till ridges and overlying ground moraine 1-5 km north and northeast of Fort Covington, N.Y., was described by Richard (1977). The fossiliferous till ridges are common in New York east, south, and west of Fort Covington (MacClintock and Stewart, 1965, pl. 1B). The ridges are capped or discontinuously veneered by fossiliferous till-like debris as much as $3 \mathrm{~m}$ thick; the lithology of the diamicton is similar to that of the underlying till (MacClintock and Stewart, 1965, p. 36, $72,75-78$ ). The diamicton is not a till that was deposited as a result of a post-"Fort Covington" glacial readvance (Macclintock and Stewart, 1965; Carl, 1977); it is a reworked deposit produced by waves, currents, and tides in the Champlain Sea. MacClintock and Stewart (1965, p. 78) concluded, "The winnowed till is a blanket of fossiliferous debris, made by churning up of the surface part of the till and the winnowing out of the silt and clay, leaving a residue with marine shells in it." Similar reworked till on the Drummondville moraine in Quebec was described by Gadd (1971). Published data favor a marine origin of all the shell-bearing diamictons attributed to the "Newington readvance" in New York, Quebec, and Ontario.

\section{NOTE 35}

The glacial-lake history in central New York is based on the succession of lakes outlined by Fairchild (numerous publications, 1896-1934), Watson (1898), Chadwick (1917,1923), Brainerd (1922), Chadwick and Dunbar (1924), and Miner (1933). More recent studies by Chisnell (1951), Shumaker (1957), Coon (1960), Sissons (1960), Von Engeln (1961), Caggiano (1966), and Krall (1966) provided critical data used in reconstruction of the lake history in the Finger Lakes region.

\section{NOTE 36}

The name Fort Covington Till is cited as an example of a formal rock-stratigraphic unit (formation) in the Code of Stratigraphic Nomenclature (American Commission on Stratigraphic Nomenclature, 1961, p. 652). Macclintock (1954a, 1958), MacClintock and Terasmae (1960), MacClintock and Dreimanis (1964), and MacClintock and Stewart (1965) did not attempt or intend to define the till as a formal stratigraphic unit.

The "Fort Covington" till and the older "Malone" till (both informal) in the spectacular sections of the St. Lawrence Seaway and power-project excavations were texturally distinctive and were separated by nonglacial sediments (MacClintock, 1958; Trainer and Salvas, 1962; MacClintock and Dreimanis, 1964; MacClintock and Stewart, 1965; Terasmae, 1965). Elsewhere in New York, Ontario, and Quebec, tills also referred to as "Fort Covington" and "Malone" tills have been distinguished primarily on the basis of till fabric; in most places a definite contact between tills of demonstrably different ages has not been identified, and lithologic and textural criteria have not been used 
to identify or differentiate the tills. Recent studies in parts of Ontario (Gwyn and Thibault, 1974; Sharpe, 1974) and New York (Denny, 1974) failed to provide stratigraphic grounds for differentiation of "Malone" and "Fort Covington" tills. In those areas the "Malone"-"Fort Covington" succession (defined on the basis of striations, till fabrics, and other indicators of ice-movement directions) apparently represents a change in direction of ice movement in response to increased influence of physiography on ice-margin lobation during deglaciation, rather than two advances of an ice margin. The "Malone" and "Fort Covington" tills in the St. Lawrence Seaway and powerplant excavations were deposited during different stadials; the tills referred to as "Malone" and "Fort Covington" on the north margin of the Adirondack Mountains and in many other places in New York and Ontario both apparently were deposited during the stadial represented by the single "Fort Covington" till in the seaway sections.

In view of the uncertainty of the relationships in time and space between the "Malone" and "Fort Covington" tills in the seaway and powerplant exposures and tills elsewhere in New York, Ontario, and Quebec (identified on the basis of till fabrics), the name "Fort Covington" has little value for purposes of correlation and reconstruction of glacial and deglacial history. The "Malone" and "Fort Covington" tills were not defined as formal rock-stratigraphic units (formations). The tills were not defined or differentiated on the basis of lithologic and textural characteristics; boundaries and contact relationships were not adequately specified; and type sections were not designated. Consequently, the names Fort Covington Till and Malone Till should be removed from formal rock-stratigraphic nomenclature and new names should be proposed for the tills in the St. Lawrence Seaway and power plant exposures.

Deposition of the youngest till on the north margin of the Adirondack Mountains antedated expansion of Lake Iroquois into the St. Lawrence Lowland (MacClintock and Terasmae, 1960; MacClintock and Stewart, 1965), and it may have antedated formation of Lake Iroquois in the Lake Ontario basin. The youngest "Fort Covington" readvance on the north margin of the Adirondacks and in the Black River Lowland is very tentatively correlated with the readvance that resulted in deposition of the Halton Till in Lake Ontario basin. (See Supplementary Note 41.)

\section{NOTE 37}

LaFleur (1975) proposed that extinction of Lake Amsterdam in the Mohawk Lowland occurred during the Erie interstadial. That interpretation is not accepted here. The Rosendale readvance in the Hudson Lowland (Connally, 1968; Connally and Sirkin, 1973) and the Yosts readvance in the eastern Mohawk Lowland (Yatsevitch, 1969; LaFleur, 1969) antedated extinction of Lake Amsterdam. Assignment of an Erie interstadial age to extinction of Lake Amsterdam requires that the Rosendale advance and all older advances in the Hudson Lowland and in New Jersey antedated the Port Bruce Stadial and that the lower Hudson Lowland was deglaciated before 16,000 B.P. Chronologic and stratigraphic data from the central and southern Hudson Lowland, northern New Jersey, and southwestern New England (Schafer and Hartshorn, 1965; Epstein, 1969; Sirkin and Minard, 1972; Connally and Sirkin, 1973; Borns, 1973) suggest that active ice was present in these regions during the Port Bruce stadial.

The Luzerne readvance in the Glens Falls region (Supplementary Note 44) occurred during the latter part of the Port Bruce stadial; the readvance antedated extinction of Lake Albany (Connally and Sirkin, 1969, 1971, 1973). A bog on drift of the Luzerne advance yielded radiocarbon ages of $12,150 \pm 200$ B.P. (I-4986) and $12,400 \pm 200$ B.P. (I-3199). Connally and Sirkin $(1971,1973)$ inferred that culmination of the readvance occurred approximately 13,200 B.P. If their interpretation is correct, culmination of the readvance of at least $33 \mathrm{~km}$ was synchronous with maximum ice-margin recession during the Mackinaw interstadial in the Lake Michigan, Lake Huron, Lake Erie, and Lake Ontario basins. The radiocarbon sample from the base of the bog (I-4986) does not necessarily provide a close minimum age for deglaciation; the Luzerne advance probably occurred much earlier during the Port Bruce stadial. (See discussion under "Radiocarbon Ages.")

LaFleur (1975) proposed that extinction of Lake Amsterdam was followed by (a) formation of the Schenectady delta in Lake Albany, (b) continued northward expansion of Lake Albany in the Hudson Lowland, (c) minor readvances of the ice margin into Lake Albany during the "Cary Stade," and (d) successive lowering of waters in the Hudson Lowland from the Albany level to the Quaker Springs and Coveville levels during the "Cary-Port Huron interstade" and the "Port Huron Stade." If extinction of Lake Amsterdam occurred during the Erie interstadial, as LaFleur proposed, the Port Bruce stadial is represented only by "several minor readvances of ice defending Lake Albany" (LaFleur, 1975) and the Luzerne readvance. All the Port Bruce stadial readvances, therefore, were confined to a relatively small area of the Hudson Lowland between Schenectady and Albany on the south, and Glens Falls on the north. 
The list of Champlain Sea ages shown on the plate is incomplete. The oldest shell ages appear to be too old in relation to ages of Lake Iroquois phases and other lake phases in the Great Lakes region. The possibility of carbon isotope fractionation (Mangerud, 1972) in Champlain Sea materials is being reinvestigated by Claude Hillaire-Marcel (V. K. Prest, written commun., 1976). Wood in association with shells in growth position on Mont St. Hilaire, Quebec, and wood in association with shells near Quebec City may provide calibration for shell ages. Uncorrected ages from Mont St. Hilaire suggest that shells may provide ages 700-900 years older than wood (V.K. Prest, Geological Survey of Canada, written commun., 1976); on the other hand, the preliminary wood and shell ages from Quebec City are in agreement within the limits of the statistical errors of the measured ages. In Vermont, wood and shells in Champlain Sea sediments from a single locality yielded ages of $10,950 \pm 300(\mathrm{~W}-2309)$ and $11,420 \pm 350$ (W-2311), respectively (Wagner, 1972).

\section{NOTE 39}

Radiocarbon controls do not permit close resolution of the ages of the Lac St. Charles moraine (LaSalle, $1970)$ and the younger St. Narcisse moraine system in Quebec. Shells in growth position in stony glaciomarine sediment yielded an age of $11,600 \pm 160$ B.P. (GSC-1235) (Gadd, McDonald, and Shilts, 1972; LaSalle and others, 1972; Gadd, LaSalle, Dionne, Shilts, and McDonald, 1972; LaSalle and Elson, 1975). The shells are from a locality approximately $80 \mathrm{~km}$ south of the St. Narcisse moraine. If the diamicton is not older till that was redeposited by waves and currents in the Champlain Sea (Supplementary Note 34), the sample may provide an approximate age of the Lac St. Charles moraine and a maximum age of the St. Narcisse moraine system (Gadd, LaSalle, Dionne, Shilts, and McDonald, 1972, p. 35).

Foraminifera from stony marine drift beneath till in the St. Narcisse moraine (Gadd, LaSalle, Dionne, Shilts, and McDonald, 1972, p. 64-65) yielded an age of $11,600 \pm 630$ B.P. (GSC-1526). The sample provides a minimum age for the Lac St. Charles moraine and an approximate age or maximum age for the St. Narcisse moraine. The age should be treated with caution, owing to the small size of the sample and the large statistical error of the measured age.

Shells in glaciomarine sediments inferred to have been deposited contemporaneously with formation of the St. Narcisse moraine system yielded an age of $11,300 \pm 160$ B.P. (GSC-1729) (Occhietti, 1976). If the diamicton is not redeposited older till, the sample may provide an approximate age of the moraine system.

Barnacles in till (LaSalle and others, 1972; Gadd, LaSalle, Dionne, Shilts, and McDonald, 1972) or glaciomarine sediment (LaSalle and Elson, 1975) south of the St. Narcisse moraine system yielded an age of $11,200 \pm 160$ B.P. (GSC-1295). The sample provides a minimum age for the Lac St. Charles moraine. Barnacles in a lens of till (Gadd, LaSalle, Dionne, Shilts, and McDonald, 1972, table 5-1), marine sediment (Gadd, LaSalle, Dionne, Shilts, and McDonald, 1972, table II), or stony glaciomarine sediment (LaSalle and Elson, 1975) in ice-contact stratified drift south of the St. Narcisse moraine system yielded an age of $11,200 \pm 170$ B.P. (GSC-1476). Barnacle and shell fragments from till (Gadd, McDonald, and Shilts, 1972; Gadd, LaSalle, Dionne, Shilts, and McDonald, 1972, table II) or stony marine clay (LaSalle and others, 1972; Gadd, LaSalle, Dionne, Shilts, and McDonald, 1972, table 5-1; LaSalle and Elson, 1975) south of the St. Narcisse moraine system yielded an age of $11,100 \pm 160$ B.P. (GSC-1232). If the three diamictons are related to the St. Narcisse readvance, the ice margin apparently advanced beyond the position of the St. Narcisse moraine, and the samples provide approximate ages of the St. Narcisse readvance. If the clasts in any of the materials are rafted debris from the St. Narcisse ice margin, the samples provide approximate ages of the readvance. If any of the samples are from redeposited older till (Supplementary Note 34), the samples have no bearing on the age of the moraine system.

Minimum ages of the St. Narcisse moraine system are provided by radiocarbon samples from nonglacial sediments on the north of the system (GSC-2045, GSC-2101, I-491, Gif-424, GSC-1444, GSC-1739).

\section{NOT́E 40}

The history of lake-level changes in the Hudson and Champlain Lowlands is poorly known. The configuration of isobases in the Lowlands is controversial, in part because the lakes were narrow, in part because of difficulties in distinguishing deltas and other features of major lakes from ice-contact deposits and deltas formed in local ice-dammed lakes, and in part because different authors have adopted different models of differential postglacial uplift. Also, owing to the limited areal extent and discontinuous distribution of strand features and the occurrence of strands of a specific lake phase at different altitudes at a given location on projected profiles of postglacial uplift, all the highest strand segments on projected profiles are connected to provide an upper limit of the lake (for examples see 
LaFleur, 1965c, fig. 11; Wagner, 1969, fig. 2; Denny, $1967,1970)$. Thus, the altitude assigned to a lake is the projected and extrapolated upper limit of all strand segments formed in the lake, and the possibility of crossing or splitting of strands has not been explored.

Reeds (1927) concluded that Lake Hackensack in the New Jersey Meadows, Lake Hudson in the Hudson River valley south of the Hudson Highlands, and Lake Flushing in Long Island Sound were confluent, and that the waters did not extend north of the Hudson Highlands. Connally (1972a) proposed that all three of Reeds' lakes were confluent with Lakes Albany and Quaker Springs north of the Highlands. Resolution of the relationships between lake levels north and south of the Highlands has a direct bearing on the debated origin and location of the dam of Lake Albany.

LaFleur (1965c) and Connally (1972a) concluded that the Quaker Springs phase of "Lake Vermont" and a second phase of Lake Albany were confluent, and that the Coveville phase of "Lake Vermont" and a third phase of Lake Albany were confluent. LaFleur concluded that the Lake Fort Ann phase of "Lake Vermont" and a fourth phase of Lake Albany were confluent; Connally proposed that Lake Fort Ann was confined to the Champlain Lowland, but he also noted that the projected upper limit of Lake Fort Ann is above the presumed outlet of Lake Fort Ann. Denny (1974) identified two Lake Fort Ann levels in the north end of the Champlain Lowland. The published data are compatible with a third interpretation, that an early phase of Lake Fort Ann was confluent with a fourth phase of Lake Albany, and a later phase of Lake Fort Ann was confined to the Champlain Lowland. Because Lakes Quaker Springs and Coveville (and early Lake Fort Ann?) in the Champlain Lowland were confluent with waters in the Hudson Lowland, Connally (1970) suggested that the name "Lake Vermont" be eliminated from terminology in the Champlain Lowland.

Denny (1974) suggested that the younger of two inferred levels of Lake Fort Ann at the International Boundary, correlated with confluent waters in the Lake Ontario basin and the Champlain Lowland, was at least $15 \mathrm{~m}$ higher than the earlier level. This configuration of strands is inconsistent with the expected pattern of differential uplift in the Champlain Lowland; strands of the earlier level are expected to be higher than those of the later level. The upper limit of Champlain Sea sediments also is tilted more steeply than the upper limit of the older Lake Fort Ann Sediments (Denny, 1967, 1970, 1974). The anomalous relationships can be explained by (a) misinterpretation of the relative ages of the two Fort Ann levels; (b) miscorrelation of levels in the northern and southern parts of the Lowland; (c) more rapid differential uplift in the southern part of the Lowland than in the northern part of the Lowland (suggested by Denny, 1974); (d) Holocene tectonic movement in the Adirondack Mountains and Champlain Lowland (Isachsen, 1975a, 1975b; Isachsen and Wold, 1977); and (e) splitting of Lake Fort Ann strands in the central part of the Lowland as a result of a glacial readvance into Lake Fort Ann. More rapid uplift in the southern part of the Lowland (alternative "c") or Holocene tectonic activity (alternative " $d$ ") should be reflected in the projected profiles of strands of other lakes in the Hudson and Champlain Lowlands; the absence of such evidence argues against these hypotheses. Alternative " $e$ " requires that the upper limit of Lake Fort Ann in the southern part of the Champlain Lowland represents two phases of Lake Fort Ann; however, the upper limit in the northern part of the Lowland represents only the second phase of Lake Fort Ann.

Wagner $(1969,1970,1972)$ suggested that a very low level lake existed in the Champlain Lowland after extinction of Lake Fort Ann. If this "Lake New York" existed, it antedated transgression of the Champlain Sea and drained northward to the St. Lawrence Lowland. An interval of northward drainage prior to the marine transgression is not recorded in published studies of the St. Lawrence Lowland, however.

\section{NOTE 41}

The "Mountain-front" moraine system (Denny, 1966) consists of end-moraine segments of several ages (Denny, 1974). As mapped in 1966, the system includes moraine segments of ice-margin stands $2 a, 2 b, 3 a, 3 b$, and $4 a$, as mapped more recently (Denny, 1974). Most of the ice-margin positions inferred on the small-scale maps (Denny, 1974, fig. 11, pl. 1) are not indicated on maps by Woodworth $(1905 \mathrm{a}, 1905 \mathrm{~b})$ or on more detailed quadrangle maps by Denny $(1967,1970)$. In view of Denny's revisions of ice-margin positions in the northeastern Adirondack Mountains, the term "Mountain-front moraine" should be redefined or should be abandoned.

Denny (1974) tentatively correlated the Highland Front moraine system, in Quebec, with his "ice margin stand no. 1" (Loon Lake episode) in the northeastern Adirondack Mountains. The Loon Lake episode antedated Lake Fort Ann; if it represents a glacial readvance it may have been contemporaneous with the Bridport advance of Connally (1970) and Connally and Sirkin $(1971,1973)$ in the Champlain Lowland. The Highland Front moraine system was formed during the existence of Lake Fort Ann (McDonald, 1967, 1968b; Connally and Sirkin, 1973). 
A glacial readvance in the Champlain Lowland, during the existence of Lake Fort Ann and synchronous with the readvance to the position of the Highland Front moraine, may be represented by "ice stand no. 8" (the Clinton Mills, Ellenburg Depot, and Miner Lake moraines) of Denny (1974, figs. 5, 6, 11, pls. 1, 5, 6). Denny inferred that the ice margin trended southeast toward the Lake Champlain basin from a position northwest of West Beekmantown; on Woodworth's map (1905a, pl. 2) the ice margin is inferred to have continued southwest, toward Cadyville.

The termination of Lake Coveville strands northeast of Cadyville and northwest of West Plattsburgh (Chapman, 1937, 1942; Denny, 1967, 1974) may mark the approximate position of the ice margin at the time of culmination of the proposed Clinton Mills-Ellenburg Depot (equal to Highland Front) readvance. The Lake Coveville-Lake Fort Ann transition occurred prior to the proposed readvance-Lake Coveville sediments probably extended farther north at the time of Coveville extinction; they and the earliest Lake Fort Ann sediments were overridden by the readvancing ice margin.

Denny (1974) tentatively correlated the "Fort Covington" till boundary of MacClintock and Stewart (1965) with his "ice stand no. 14," on the north flank of Covey Hill. This correlation is compatible with mapping of the "Fort Covington" till boundary (on the basis of till fabrics) by MacClintock (1958), MacClintock and Terasmae (1960), and MacClintock and Stewart (1965), but the location and significance of the "Fort Covington" till boundary are themselves subjects of debate (Supplementary Note 36). The "Fort Covington" boundary of MacClintock and Stewart $(1965$, pl. 1) is less than $4 \mathrm{~km}$ north of Denny's "ice stand no. 8," here correlated with the Highland Front moraine. Some-but not all-of the "Fort Covington" ice-margin positions described by MacClintock and Stewart (1965) represent a significant glacial readvance on the north margin of the Adirondacks, and some of the "Fort Covington" moraine segments may have been formed as a result of the same readvance that produced the Clinton Mills-Ellenburg Depot and Highland Front moraines. The "Fort Covington" moraine segments (regardless of their ages and correlations) and the Clinton Mills, Ellenburg Depot, and Miner Lake moraines all were formed prior to expansion of Lake Iroquois along the north margin of the Adirondack Mountains.

\section{NOTE 42}

Although a number of significant morphologic studies have been conducted in the Hudson and
Champlain Lowlands during the past two decades, the stratigraphy and chronology of the regions are not well known. The stratigraphic and morphologic data included in pioneering studies of S. P. Baldwin, E. E. Barker, G. H. Chadwick, D. H. Chapman, J. H. Cook, H. L. Fairchild, C. H. Hitchcock, F. H. J. Merrill, H. E. Merwin, C. E. Peet, G. H. Perkins, C. A. Reeds, R. D. Salisbury, J. H. Stoller, W. E. Upham, J. B. Woodworth, and G. F. Wright have been generally ignored. They must be incorporated into any realistic reconstruction of the glacial and deglacial history of the Lowlands.

G. G. Connally and L. A. Sirkin (1966-73) constructed a chronologic framework of events in the Hudson Lowland and the southern part of the Champlain Lowland. Their interpretations were based chiefly on landforms and pollen analysis. The radiocarbon ages that provided the time framework for their scheme all are minimum ages, and the ages of events are not necessarily closely limited by the radiocarbon ages. (See discussion under "Radiocarbon Ages".) The succession of events proposed by Connally and Sirkin is not questioned here; the ages of events are not firmly established, and, consequently, correlation of the events with events elsewhere is conjectural. Many of their interpretations are accepted here; others are considered less probable than correlations shown on the plate.

NOTE 43

Evidence of northward movement of ice in Quebec, cited by Clark (1937) and Cooke (1937), was debated by Flint (1951), Thornes (1965), McDonald (1967, 1968a, 1968b), and McDonald and Shilts (1971). Still more recent studies by LaMarche $(1971,1974)$, Gadd, McDonald, and Shilts (1972), Lortie (1975), Gauthier (1975), and Gadd (1976) have confirmed that northward movement of ice did occur in the Thetford Mines-Asbestos region. The northward movement occurred prior to formation of the Highland Front moraine system (Sabourin, 1957; Map 10-1971 in Gadd, McDonald, and Shilts, 1972) and thus prior to transgression of the Champlain Sea. Gadd, McDonald, and Shilts (1972) and Gadd (1976) proposed that striations and the distribution of indicator lithologies in till are evidence that a local center of ice dispersal covered the central part of the Chaudiére River valley in Quebec, contemporaneous with formation of the Cherry River moraine at the margin of the Laurentide ice sheet. It is not clear why a local center of ice dispersal formed in the Lowland rather than on the Appalachian Highland to the east and southeast. Gauthier (1975) proposed that the center of outflow of 
a residual icecap was in the Appalachian region south of the Chaudiere River Valley and that formation of the local ice center was caused by transgression of the Champlain Sea in the Lowland. Hanson and Caldwell (1977) proposed that a local ice center formed on the Boundary Mountains, in the vicinity of Jackman, Maine, east and southeast of the proposed ice center in Quebec, and they inferred that ice may have moved northwestward into Quebec. Although northward ice movement in the Thetford Mines-Asbestos region is inferred to have occurred prior to formation of the Boundary Mountains ice center (Hanson and Caldwell, 1977), the spatial and temporal relationships of the respective ice masses have not been established.

NOTE 44

The Warrensburg, Hidden Valley, and Mt. McGregor moraines are products of a glacial readvance of at least $33 \mathrm{~km}$ in the Champlain and Hudson Lowlands (the Luzerne advance). The readvance culminated prior to the Lake Albany-Lake Quaker Springs transition (Connally and Sirkin, 1969, 1971). (See Supplementary Note 37.)

NOTE 45

Ages, correlations, and distributions of tills in Vermont are uncertain. The stratigraphic succession and areal distribution of tills outlined by Stewart (1961) and Stewart and MacClintock $(1964,1969,1970)$ are based primarily on till-fabric analysis rather than lithologic or textural distinctions; they are not compatible with the presently recognized successions of events and successions and distributions of tills in New York, Connecticut, Massachusetts, and Quebec. Although the synthesis by Stewart and MacClintock $(1969,1970)$ incorporated the work of several other investigators, much of the field data and many of the interpretations of Behling (1965, 1966), Calkin (1965), Cannon (1964a-d), Connally (1966a, 1966b, 1970), Shilts $(1965,1966 \mathrm{a}, 1966 \mathrm{~b})$ and Shilts and Behling (1967) were not included in the synthesis. Reports by Connally and Calkin (1972), Wagner (1972), Wagner, Morse, and Howe (1972), Larsen (1975), and Kelley $(1975 \mathrm{a}, 1975 \mathrm{~b})$ contain more recent data related to till stratigraphy and ice movement patterns in Vermont and neighboring states.

NOTE 46

Ages and correlations of tills, end moraines, and lakes in northern New Jersey have not been established on stratigraphic or radiometric grounds. The treatise by Salisbury, Kümmel, Peet, and Knapp (1902) and other studies by Salisbury $(1902,1908 a$, 1908b) and Bayley, Kümmel, and Salisbury (1914) are the most comprehensive references on the Quaternary geology of northern New Jersey. Detailed studies of till stratigraphy have not been published, although exposures of multiple tills are common. Discontinuous segments of end-moraine and other ice marginal features are common in New Jersey, but correlation of segments is conjectural. Herpers (1961), Minard (1961), Connally and Sirkin (1967, 1970, 1973), and Minard and Rhodehamel (1969) attempted to trace icemargin positions across Kittatinny Mountain and the New Jersey Highlands, but their correlations are not in agreement. The correlations of end-moraine segments proposed in plate 1 are based on my own field studies of ice marginal alinements in 1969,1970, and 1971, and they incorporate observational data from many sources. They are presented as an alternative to published correlations.

Connally and Sirkin $(1967,1970,1973)$ proposed that the Ogdensburg-Culvers Gap moraine in New Jersey is the oldest late Wisconsinan (Woodfordian) moraine in New Jersey. On the basis of extrapolation of sedimentation rates in pollen profiles, Sirkin and Minard (1972) suggested that the moraine was formed $18,300 \pm 300$ B.P., and they inferred that the moraine may be the same age as the Roslyn till on Long Island. The Ogdensburg-Culvers Gap moraine here is correlated tentatively with a glacial readvance to the north shore of western Long Island (the Port Washington advance of Woodworth, 1901). At least part of the Roslyn till is older than the Port Washington moraine (Sirkin, 1971; Mills and Wells, 1974; Sirkin and Mills, 1975). On the basis of relative age criteria Epstein (1969) and Bucek (1971) concluded that much of the drift south of the OgdensburgCulvers Gap moraine in northwestern New Jersey and northeastern Pennsylvania is late Wisconsinan in age. The terminal moraine deposits in the vicinity of Budd Lake, farther east in New Jersey, are characterized by unfilled kettles, relatively unmodified collapsed icecontact slopes, very poorly integrated drainage, and shallow soil-profile development. These deposits are older than the Ogdensburg-Culvers Gap moraine, but do not appear to be early or middle Wisconsinan in age.

Averill (1975) suggested that a glacial readvance occurred in the Hackensack and southern Hudson River valleys after deposition of peat which yielded a radiocarbon age of $9,125 \pm 150$ B.P. (I-6286). Other workers concluded that New England, New York, and southeastern Quebec were deglaciated long before 10,000 B.P. (Borns, 1973; Coates, 1976; Gadd, 1976). A 
glacial readvance during the existence of Lake Hackensack is recorded by till, kames, and other ice-contact deposits east of Ridgewood, at the north edge of Hackensack, north of Teaneck and south of Tenafly, and at Englewood, N.J. The surface till beneath the dated peat at Hillsdale, N.J., north of the localities mentioned above, was deposited as a result of the Hackensack readvance. The peat is not overlain by the till; it postdates all glaciation and deglaciation in the Hudson and Hackensack River valleys. The sand that overlies the peat is postglacial alluvium, windblown sand, and redeposited outwash and ice-contact sediments, as are much of the sand and gravel that overlie till and Lake Hackensack and Lake Hudson sediments elsewhere in northeastern New Jersey (Salisbury, 1902, 1908a; Salisbury and others, 1902; Woodworth, 1905b; Reeds, 1927).

\section{NOTE 47}

The Lennoxville Till in southeastern Quebec (McDonald, 1967; McDonald and Shilts, 1971; Gadd, 1976) represents continuous ice cover from earlier than 16,000 B.P. until deglaciation was completed in the Southeastern Townships of Quebec.

\section{SELECTED REFERENCES}

Alden, W. C., 1902, Description of the Chicago district, IllinoisIndiana: U.S. Geol. Survey Geol. Atlas, Folio 81, 14 p.

1906, Description of the Milwaukee quadrangle, Wisconsin: U.S. Geol. Survey Geol. Atlas, Folio 140, 12 p.

1918, The Quaternary geology of southeastern Wisconsin: U.S. Geol. Survey Prof. Paper 106, 356 p.

American Commission on Stratigraphic Nomenclature, 1961, Code of stratigraphic nomenclature: Am. Assoc. Petroleum Geologists Bull., v. 45, p. 645-665.

Anderson, T. W., 1971, Postglacial vegetative changes in the Lake Huron-Lake Simcoe district, Ontario, with special reference to glacial Lake Algonquin: Univ. Waterloo, Ontario, Ph. D. dissert., $246 \mathrm{p}$.

Arnold, J. R., and Libby, W. F., 1951, Radiocarbon dates: Science, v. 113, p. 111-120.

Atwood, W. W., and Goldthwait, J. W., 1908, Physical geography of the Evanston-Waukegan region: Illinois Geol. Survey Bull. 7, $102 \mathrm{p}$.

Averill, S. P., 1975, Multiple Wisconsin glaciation of the Hudson and Hackensack valleys: Geol. Soc. America. Abs. with Programs, v. 7, no. 1, p. 23.

Axford, R. S., 1951, Glacial beaches and spillway banks of the city of London: Univ. Western Ontario, Ontario, B.S. thesis, pages unknown.

Baker, F. C., 1920, The life of the Pleistocene or glacial period as recorded in the deposits laid down by the great ice sheets: Illinois Univ. Bull., v. 17, no. 41, 476 p.

1926, Bowmanville low-water stage of glacial Lake Chicago: Science, new ser., v. 64, p. 249.

Baker, Jack, 1957, Glacial geology of Geauga County, Ohio: Illinois Univ. Ph. D. dissert., 118 p.
Baker, M. B., and Johnston, W. A., 1934, Glacial lake stages about the east end of Lake Ontario: Royal Soc. Canada Trans., v. 28, sec. 4 , p. $75-80$

Baldwin, S. P., 1894, Pleistocene history of the Champlain Valley: Am. Geologist, v. 13, p. 170-184.

Barendsen, G. W., Deevey, E. S., Jr., and Gralenski, L. J., 1957, Yale natural radiocarbon measurements III: Science, v. 126, p. 908-919.

Barker, E. E., 1916, Ancient water levels of the Crown Point embayment: New York State Mus. Bull. 187, p. 165-190.

Barnett, P. J., 1975a, Quaternary geology of the Simcoe (40 I/16) area, Norfolk and Haldiman Counties: Ontario Div. Mines Misc. Paper 63, p. 121-123.

$1975 \mathrm{~b}$, Till matrix characteristics of the upper and lower tills of the Niagara Peninsula, Ontario: Univ. Waterloo, Ontario, M.S. thesis, pages unknown.

1976, Quaternary geology of the Tillsonburg (40 I/15) area, Brant, Oxford, Elgin, Middlesex, and Norfolk Counties: Ontario Div. Mines Misc. Paper 67, p. 148-149.

Bayley, W. S., Kümmel, H. B., and Salisbury, R. D., 1914, Description of the Raritan quadrangle [New Jersey]: U.S. Geol. Survey Geol. Atlas, Folio 191, 32 p.

Behling, R. E., 1965, A detailed study of the Wisconsin stratigraphic sections of the upper Lamoille valley, north-central Vermont: Miami Univ., Ohio, M.S. thesis, 125 p.

1966, Surficial geology of the Equinox, Londonderry, and Pawlet quadrangles, Vermont: Vermont Geol. Survey open-file report to the State Geologist, pages unknown.

Bender, M. M., Bryson, R. A., and Baerreis, D. A., 1965, University of Wisconsin radiocarbon dates I: Radiocarbon, v. 7, p. 399-407. 1970, University of Wisconsin radiocarbon dates VII: Radiocarbon, v. 12, no. 1, p. 335-345.

1971, University of Wisconsin radiocarbon dates IX: Radiocarbon, v. 13, no. 2, p. 475-486.

1975, University of Wisconsin radiocarbon dates XII: Radiocarbon, v. 17, no. 1, p. 121-134.

Benninghoff, W. S., and Hibbard, C. W., 1961, Fossil pollen associated with a late-glacial woodland musk ox in Michigan: Michigan Acad. Sci., Arts and Letters Papers, 1960, v. 46, pt. 1, p. 155-159.

Bergquist, S. G., [no date], Guidebook to the study of Pleistocene features related to the activities of the Michigan lobe and subsidiary ice tongues, northwest section of the Southern Peninsula of Michigan: Michigan State Univ., Dept. Geology, 33 p.

Bergquist, S. G., and MacLachlan, D. C., 1951, Pleistocene features of the Huron-Saginaw ice lobes in Michigan: Geol. Soc. America Guidebook, Detroit Mtg., 36 p.

Bermingham, Anne, 1966, Victoria natural radiocarbon measurements I: Radiocarbon, v. 8, p. 507-521.

Bieber, C. L., 1951, Toleston and post-Toleston beaches and bars in Lake County, Indiana: Indiana Acad. Sci. Proc., 1951, v. 61, p. 176-179.

Black, R. F., 1966, Valders glaciation in Wisconsin and upper Michigan-A progress report, in Great Lakes Research Conference, 9th, Chicago, 1966, Proceedings: Univ. Michigan, Great Lakes Research Div. Pub. 15, p. 169-175.

1969, Valderan glaciation in western upper Michigan; in Great Lakes Research Conference, 12th, Ann Arbor, Mich., 1969, Proceedings: Internat. Assoc. Great Lakes Research, p. 116-123.

1970a, Glacial geology of Two Creeks forest bed, Valderan type locality, and northern Kettle Moraine State Forest: Wisconsin Geol. and Nat. History Survey Inf. Circ. 13, 40 p. 
$1970 \mathrm{~b}$, Chronology and climate of Wisconsin and upper Michigan-14,000 to 9,000 radiocarbon years ago: Am. Quaternary Assoc. Mtg., 1st, Yellowstone Park, Wyo., and Bozeman, Mont., 1970, Abs., p. 12.

1974a, Late Pleistocene shorelines and stratigraphic relations in the Lake Michigan basin-Discussion: Geol. Soc. America Bull., v. 85, p. 659-660.

1974b, Geology of Ice Age National Scientific Reserve of Wisconsin: U.S. Nat. Park Service Sci. Mon. Ser. 2, 234 p.

1976, Quaternary geology of Wisconsin and contiguous upper Michigan, in W. C. Mahaney, ed., Quaternary stratigraphy of North America: Stroudsburg, Pa., Dowden, Hutchinson, and Ross, p. 93-117.

1978, Comment on "Greatlakean Substage: a replacement for Valderan Substage in the Lake Michigan basin" by E. B. Evenson, W. R. Farrand, D. F. Eschman, D. M. Mickelson, and L. J. Maher: Quaternary Research, v. 9, no. 1, p. 119-123.

Black, R. F., Bleuer, N. K., Hole, F. D., Lasca, N. P., and Maher, L. J., Jr., 1970, Pleistocene geology of southern Wisconsin: Wisconsin Geol. and Nat. History Survey Inf. Circ. 15, 175 p.

Black, R. F., Hole, F. D., Maher, L. J., and Freeman, J. E., 1965, The Wisconsin Quaternary: Internat. Assoc. Quaternary Research Cong., 7th, U.S.A., 1965, Guidebook for Field Conference C, Upper Mississippi Valley, p. 56-81.

Black, R. F., and Rubin, Meyer, 1968, Radiocarbon dates of Wisconsin: Wisconsin Acad. Sci., Arts and Letters, Trans. 1967-68, v. 56, p. 99-115.

Blackmon, P. D., 1956, Glacial geology of the East Aurora, New York, quadrangle: State Univ. New York at Buffalo, M.A. thesis, $100 \mathrm{p}$.

Bleuer, N. K., 1974a, Buried till ridges in the Fort Wayne area, Indiana, and their regional significance: Geol. Soc. America Bull., v. 85, p. 917-920.

$1974 \mathrm{~b}$, Distribution and significance of some ice-disintegration features in west-central Indiana: Indiana Geol. Survey Occasional Paper 8, $11 \mathrm{p}$.

1975, The Stone Creek section, a historical key to the glacial stratigraphy of west-central Indiana: Indiana Geol. Survey Occasional Paper 11, 9 p.

Bleuer, N. K., and Moore, M. C., 1972a, Glacial stratigraphy, buried landforms and early drainage at Fort Wayne, Indiana: Geol. Soc. America Abs. with Programs, v. 4, no. 5, p. 309-310.

$1972 \mathrm{~b}$, Glacial stratigraphy of the Fort Wayne area and the draining of glacial Lake Maumee: Indiana Acad. Sci. Proc., 1971 , v. 81, p. $195-209$.

1975, Buried pinchout of Saginaw lobe drift in northeastern Indiana: Indiana Acad. Sci. Proc., 1974, v. 84, p. 362-372.

Borns, H. W., Jr., 1973, Late Wisconsin fluctuations of the Laurentide ice sheet in southern and eastern New England, in R. F. Black, R. P. Goldthwait, and H. B. Willman, eds., The Wisconsinan Stage: Geol. Soc. America Mem. 136, p. 37-45.

Borns, H. W., Jr., and Denton, G. H., 1972, Port Huron readvance in eastern North America (?): Geol. Soc. America Abs. with Programs, v. 4 , no. 7 , p. 455 .

Brainerd, W. F., 1922, Dana Glacial Lake terrace and the great delta of Onondaga Valley: Syracuse Univ., M.S. thesis, 19 p.

Bretz, J H., 1939, Geology of the Chicago region, Part 1-General: Illinois Geol. Survey Bull. 65, 118 p.

1951a, Causes of the glacial lake stages in Saginaw basin, Michigan: Jour. Geology, v. 59, p. 244-258.

$1951 \mathrm{~b}$, The stages of Lake Chicago-Their causes and correlations: Am. Jour. Sci., v. 249, p. 401-429.

1953, Glacial Grand River, Michigan: Michigan Acad. Sci. Arts and Letters, Papers, 1952, v. 38, p. 359-382.

1955, Geology of the Chicago region, Pt. 2-The Pleistocene: Illinois Geol. Survey Bull. 65, 132 p.
1959, The double Calumet stage of Lake Chicago: Jour. Geology, v. 67, p. 675-684.

1964, Correlation of glacial lake stages in the Huron-Erie and Michigan basins: Jour. Geology, v. 72, p. 618-627.

1966, Correlation of glacial lake stages in the Huron-Erie and Michigan basins: Jour. Geology, v. 74, p. 78-79.

Brigham, A. P., 1897, Glacial flood deposits of the Chenango valley: Geol. Soc. America Bull., v. 8, p. 17-30.

1898, Topography and glacial deposits of the Mohawk valley: Geol. Soc. America Bull., v. 9, p. 183-210.

1929, Glacial geology and geographic conditions of the lower Mohawk valley: New York State Mus. Bull. 280, 133 p.

1931, Glacial problems in central New York: Assoc. Am. Geographers Annals, v. 21, p. 179-206.

Broecker, W. S., and Farrand, W. R., 1963, Radiocarbon age of the Two Creeks forest bed, Wisconsin: Geol. Soc. America Bull., v. 74, p. 795-802.

Broecker, W. S., and Kulp, J. L., 1957, Lamont natural radiocarbon measurements IV: Science, v. 126, p. 1324-1334.

Bucek, M. F., 1971, Surficial geology of the East Stroudsburg 71/2minute quadrangle, Monroe County, Pennsylvania: Pennsylvania Geol. Survey Atlas 214C, 40 p.

Buckley, J. D., 1976, Isotopes' radiocarbon measurements XI: Radiocarbon, v. 18, no. 2, p. 172-189.

Buckley, J. D., Trautman, M. A., and Willis, E. H., 1968, Isotopes' radiocarbon dates VI: Radiocarbon, v. 10, no. 2, p. 246-294.

Buckley, J. D., and Willis, E. H., 1970, Isotopes' radiocarbon measurements VIII: Radiocarbon, v. 12, no. 1, p. 87-129.

1972, Isotopes' radiocarbon measurements IX: Radiocarbon, v. 14 , no. 1 , p. 114-139.

Buddington, A. F., 1934, Geology and mineral resources of the Hammond, Antwerp, and Lowville quadrangles: New York State Mus. Bull. 296, 182 p.

Buddington, A. F., and Leonard, B. F., 1962, Regional geology of the St. Lawrence County magnetite district, northwest Adirondacks, New York: U.S. Geol. Survey Prof. Paper 376, 145 p.

Burgis, W. A., 1970, The Imlay outlet of glacial Lake Maumee, Imlay City, Michigan: Univ. Michigan M.S. thesis, 74 p.

Burwasser, G. J., 1973, Quaternary geology of the Collingwood and Nottawasaga area, șouthern Ontario: Ontario Div. Mines Misc. Paper 56, p. 185-187.

1974, Quaternary geology of the Barrie and Orr Lake areas, southern Ontario: Ontario Div. Mines Misc. Paper 59, p. 186-188.

Cadwell, D. H., 1972a, Late Wisconsinan deglaciation chronology of the Chenango River valley and vicinity, New York: State Univ. New York at Binghamton, Ph. D. dissert., 131 p.

1972b, Glacial geology of the northern Chenango River valley, in J. McLelland, ed., Field trip guidebook: New York State Geol. Assoc., 44th Ann. Mtg., 1972, p. D1-D15.

1973, Bedrock control of Late Wisconsinan ice retreatal positions and meltwater channels near Hamilton, New York: Geol. Soc. America Abs. with Programs, v. 5, no. 2, p. 144.

Caggiano, J. A., Jr., 1966, Glacial drainage history and drift petrography of the Vernon, New York, quadrangle: Syracuse Univ. M.S. thesis, 104 p.

Calkin, P. E., 1965, Glacial geology of the Middlebury 15-minute quadrangle: Vermont Geol. Survey open-file report to the State Geologist, pages unknown.

1966, Late Pleistocene history of northwestern New York, in E. J. Buehler, ed., Geology of western New York: New York State Geol. Assoc., Guidebook, 38th Ann. Mtg., Buffalo, 1966, p. 58-68.

1968, Glaciolacustrine strand lines and late Pleistocene history of Lake Erie basin, northwestern New York-A progress report: Coastal Research Notes, v. 2, no. 7, p. 15-20. 
1970, Strand lines and chronology of the glacial Great Lakes in northwestern New York: Ohio Jour. Sci., v. 70, p. 78-96.

Calkin, P. E., Brett, C. E., and Krajewski, J. L., 1975, Ancestral Niagara River deposits-stratigraphy and paleontology: Geol. Soc. America Abs. with Programs, v. 7, no. 1, p. 37.

Calkin, P. E., and McAndrews, J. H., 1969, Dating late glacial recession and vegetation in the Erie Basin, northwestern New York: Geol. Soc. America Abs. with Programs for 1969, pt. 1, Northeastern Sec., p. 5.

Calver, J. L., 1947, The glacial and post-glacial history of the Platte and Crystal Lake depressions, Benzie County, Michigan, in Occasional papers for 1946 on the geology of Michigan: Michigan Geol. Survey Pub. 45, Geol. ser. 38, pt. 2, 70 p.

Campbell, L. J., 1955, The late glacial and lacustrine deposits of Erie and Huron Counties, Ohio: Ohio State Univ. Ph. D. dissert., 197 p.

Cannon, W. F., 1964a, The petrology of tills in northern Vermont: Miami Univ., Ohio, M.S. thesis, pages unknown.

1964b, The Pleistocene geology of the Enosburg Falls quadrangle, Vermont: Vermont Geol. Survey open-file report to the State Geologist, pages unknown.

$1964 c$, Pleistocene geology of the Vermont portion of the Averill and Guildhall quadrangles: Vermont Geol. Survey openfile report to the State Geologist, pages unknown.

1964d, Pleistocene geology of the northern Champlain Islands and the Alburg Peninsula: Vermont Geol. Survey openfile report to the State Geologist, pages unknown.

Carl, J. D., 1977, A ribbed moraine and drumlin transition belt in the St. Lawrence Valley, New York: Geol. Soc. America Abs. with Programs, v. 9, no. 3, p. 250-251.

Carney, Frank, 1909a, The raised beaches of the Berea, Cleveland, and Euclid sheets, Ohio: Denison Univ. Sci. Lab. Bull., v. 14, p. 262-287.

$1909 \mathrm{~b}$, The Pleistocene geology of the Moravia quadrangle,

New York: Denison Univ. Sci. Lab. Bull., v. 14, p. 335-342.

1910, The abandoned shore lines of the Oberlin quadrangle, Ohio: Denison Univ. Sci. Lab. Bull., v. 16, p. 101-117.

1911, The abandoned shorelines of the Vermillion quadrangle, Ohio: Denison Univ. Sci. Lab. Bull., v. 16, p. 233-244.

1913a, Some pro-glacial lake shorelines of the Bellevue quadrangle, Ohio: Denison Univ. Sci. Lab. Bull., v. 17, p. 231-246.

$1913 \mathrm{~b}$, Quaternary geology of the Cleveland district: available from Ohio Geological Survey, pages unknown.

1916a, The shore lines of glacial Lakes Lundy, Wayne, and Arkona, of the Oberlin quadrangle, Ohio: Denison Univ. Sci. Lab. Bull., v. 18, p. 356-361.

$1916 \mathrm{~b}$, The abandoned shore lines of the Ashtabula quadrangle, Ohio: Denison Univ. Sci. Lab. Bull., v. 18, p. 362-369.

1917, The beach ridges of the glacial lakes: available from Ohio Geological Survey, 162 p.

Chadwick, G. H., 1917, The lake deposits and evolution of the lower Irondequoit Valley: Rochester Acad. Sci. Proc., v. 5, p. $123-160$.

1923, Glacial lake problems: Geol. Soc. America Bull., v. 34, p. 499-506.

1928, Ice evacuation stages at Glens Falls, New York: Geol. Soc. America Bull., v. 39, p. 901-922.

Chadwick, G. H., and Dunbar, E. U., 1924, Genesee glacial lakes: Geol. Soc. America Bull., v. 35, p. 669-676.

Chapman, D. H., 1937, Late-glacial and postglacial history of the Champlain valley: Am. Jour. Sci., v. 34, p. 89-124.

1942, Late-glacial and post-glacial history of the Champlain valley, in Report to the State Geologist on the mineral industries and geology of Vermont, 1941-1942: Vermont Geol. Survey 23d Rept., p. 48-83.
Chapman, L. J., 1954, An outlet of Lake Algonquin at Fossmill, Ontario: Geol. Assoc. Canada Proc., v. 6, pt. 2, p. 61-68.

1975, The physiography of the Georgian Bay-Ottawa Valley area of southern Ontario: Ontario Div. Mines Geosci. Rept. 128, $33 \mathrm{p}$.

Chapman, L. J., and Putnam, D. F., 1940, The physiography of eastern Ontario: Sci. Agriculture, v. 20, p. 424-441.

1943a, The moraines of southern Ontario: Royal Soc. Canada Trans., v. 37, sec. 4, p. 33-41.

1943b, The physiography of southwestern Ontario: Sci. Agriculture, v. 24, p. 101-125.

1949, The recession of the Wisconsin glacier in southern Ontario: Royal Soc. Canada Trans., v. 43, sec. 4, p. 23-52.

1966, The physiography of southern Ontario [2d ed.J: Toronto, Univ. Toronto Press, $386 \mathrm{p}$.

Chisnell, T. C., 1951, Recognition and interpretation of proglacial strand lines in Cayuga basin: Cornell Univ., Ph. D. dissert., $64 \mathrm{p}$.

Clark, T. H., 1937, Northward moving ice in southern Quebec: Am. Jour. Sci., v. 34, p. 215-220.

Coakley, J. P., 1976, The formation and evolution of Point Pelee, western Lake Erie: Canadian Jour. Earth Sci., v. 13, p. 136-144.

Coates, D. R., 1974, Reappraisal of the glaciated Appalachian Plateau, in D. R. Coates, ed., Glacial geomorphology: State Univ. New York at Binghamton, Geomorphology Pubs., p. 205-243.

1976, Quaternary stratigraphy of New York and Pennsylvania, in W. C. Mahaney, ed., Quaternary stratigraphy of North America: Stroudsburg, Pa., Dowden, Hutchinson, and Ross, p. $65-90$.

Coates, D. R., Landry, S. O., and Lipe, W. D., 1971, Mastodon bone age and geomorphic relations in the Susquehanna Valley: Geol. Soc. America Bull., v. 82, p. 2005-2010.

Coleman, A. P., 1899a, The Iroquois beach: Canadian Inst. Trans., v. 6, p. 29-44.

1899b, Lake Iroquois and its predecessors at Toronto: Geol. Soc. America Bull., v. 10, p. 165-176.

1901a, Marine and freshwater beaches of Ontario: Geol. Soc. America Bull., v. 12, p. 129-146.

$1901 b$, Sea beaches of eastern Ontario: Ontario Dept. Mines Rept., for 1901, p. 215-227.

1904, The Iroquois beach in Ontario: Geol. Soc. America Bull., v. 15, p. 347-368.

1922, Glacial and postglacial lakes in Ontario: Toronto Univ. Studies, Biol. Ser. 21, 76 p.

1936, Lake Iroquois: Ontario Dept. Mines, 45th Ann. Rept. v. 45 , pt. 7 , p. $1-36$.

Coleman, D. D., 1973, Illinois State Geological Survey radiocarbon dates IV: Radiocarbon, v. 15, no. 1, p. 75-85.

1974, Illinois State Geological Survey radiocarbon dates V: Radiocarbon, v. 16, no. 1, p. 105-117.

Coleman, D. D., and Liu, C. L., 1975, Illinois State Geological Survey radiocarbon dates VI: Radiocarbon, v. 17, no. 2, p. 160-173.

Comstock, F. M., 1904, Ancient lake beaches on the islands of Georgian Bay: Am. Geologist, v. 33, p. 310-318.

Connally, G. G., 1961, The glacial geology of the western Finger Lakes region, New York-Progress report 2: New York State Mus. and Sci. Service, 35 p.

1964, The Almond moraine of the western Finger Lakes region, New York: Michigan State Univ., Ph. D. dissert., 102 p.

1966a, Surficial geology of the Brandon-Ticonderoga 15minute quadrangles, Vermont: Vermont Geol. Survey open-file report to the State Geologist, $41 \mathrm{p}$.

$1966 \mathrm{~b}$, Surficial geology of the Mount Mansfield 15-minute quadrangle: Vermont Geol. Survey open-file report to the State Geologist, 33 p. 
1968. The Rosendale readvance in the lower Wallkill Valley, New York, in Guidebook for field trips: Natl. Assoc. Geology Teachers, Eastern Sec., New Paltz, N.Y., 1968, p. 22-32.

1970, Surficial geology of the Brandon-Ticonderoga 15minute quadrangles, Vermont: Vermont Geol. Survey, Studies in Vermont Geology, no. 2, 45 p.

1971, Kent drift in the Prattsburg Valley, western Finger Lakes region, New York: Geol. Soc. America Abs. with Programs, v. 3, no. 1, p. 24.

1972a, Major proglacial lakes in the Hudson Valley and their rebound history: Geol. Soc. America Abs. with Programs, v. 4, no. 1, p. 10.

1972b, Proglacial lakes in the Lamoille valley, Vermont, in B. L. Doolan, and R. S. Stanley, eds., Guidebook for field trips in Vermont: New England Intercollegiate Geol. Conf., 64th Ann. Mtg., Burlington, Vt., 1972, p. 343-347.

Connally, G. G., and Calkin, P. E., 1972, Woodfordian glacial history of the Champlain lowland, Burlington to Brandon, Vermont, in B. L. Doolan, and R. S. Stanley, eds., Guidebook for field trips in Vermont: New England Intercollegiate Geol. Conf., 64th Ann. Mtg., Burlington, Vt., 1972, p. 389-397.

Connally, G. G., and Sirkin, L. A., 1967, The Pleistocene geology of the Wallkill Valley, trip A, in R. H. Waines, ed., Guidebook to field trips: New York State Geol. Assoc., 39th Ann. Mtg., New Platz, N.Y., 1967, 21 p.

1969, Deglacial history of the Lake Champlain-Lake George lowland, trip I, in [Supplement to] Guidebook to field excursions: New York State Geol. Assoc., 41st Ann. Mtg., Plattsburgh, N.Y., 1969, 20 p.

1970, Late glacial history of the upper Wallkill valley, New York: Geol. Soc. America Bull., v. 81, p. 3297-3306.

1971, The Luzerne readvance near Glens Falls, New York: Geol. Soc. America Bull., v. 82, p. 989-1007.

1973, Wisconsinan history of the Hudson-Champlain lobe, in R. F. Black, R. P. Goldthwait, and H. B. Willman, eds., The Wisconsinan Stage: Geol. Soc. America Mem. 136, p. 47-69.

Conrey, G. W., 1921, Geology of Wayne County, Ohio: Ohio Geol. Survey Bull. 24, 145 p.

Cook, J. H., 1924, The disappearance of the last glacial ice sheet from eastern New York: New York State Mus. Bull. 251, p. 158-176.

1930, Glacial geology of the Capital district: New York State Mus. Bull. 285, p. 181-199.

1935, Glacial geology of the Berne quadrangle: New York State Mus. Bull. 303, p. 222-230.

1942, Glacial geology of the Catskill quadrangle: New York State Mus. Bull. 331, p. 189-237.

1943, Glacial geology of the Coxackie quadrangle: New York State Mus. Bull. 332, p. 321-357.

Cook, R. J. B., 1951, Heavy detritals and glacial stratigraphy in southern Ontario: Univ. Western Ontario, Ontario, M.S. thesis, $82 \mathrm{p}$.

Cooke, H. C., 1937, Further note on northward moving ice: Am. Jour. Sci., v. 34, p. 221.

Coon, R. F., 1960, Surficial geology of the Syracuse East and Manlius, New York, 71/2-minute quadrangles: Syracuse Univ., M.S. thesis, $257 \mathrm{p}$.

Cooper, A. J., 1974, Quaternary geology of the Grand Bend and Parkhill areas, southern Ontario: Ontario Div. Mines Misc. Paper 59, p. 192-195.

1975, Quaternary geology of the Goderich and Seaforth areas, Huron and Perth Counties: Ontario Div. Mines Misc. Paper 63, p. 119-120.

1976a, The Quaternary geology of the Grand Bend-Parkhill area, southern Ontario: Ontario Div. Mines Open-File Rept. 5215,150 p. 1976b, Quaternary geology of the Goderich $(40 \mathrm{P} / 12)$ and Seaforth (40 P/11) areas, Huron and Perth Counties: Ontario Div. Mines Misc. Paper 67, p. 143-145.

$1976 c$, Quaternary geology of the Strathroy (40 I/14) area, Middlesex and Lambton Counties: Ontario Div. Mines Misc. Paper 67, p. 146-147.

Cooper, A. J., Cowan, W. R., and Karrow, P. F., 1977, Style of deglaciation and the interaction of the Huron and Georgian Bay lobes, southern Ontario: Geol. Soc. America Abs. with Programs, v. 9, no. 5, p. 586.

Cowan, W. R., 1972a, Quaternary geology, Orangeville area west half and Palmerston area east half, southern Ontario: Ontario Div. Mines Misc. Paper 53, p. 148-151.

$1972 \mathrm{~b}$, Pleistocene geology of the Brantford area, southern Ontario: Ontario Div. Mines and Northern Affairs, Indus. Minerals Rept. 37, 66 p.

1973, Quaternary geology of the Palmerston and Wingham areas, southern Ontario: Ontario Div. Mines Misc. Paper 56, p. 192-195.

1974a, Quaternary geology, Wingham and Lucknow areas, southern Ontario: Ontario Div. Mines Misc. Paper 59, p. 189-191. $1974 \mathrm{~b}$, Quaternary geology of the Orangeville area, southern Ontario: Ontario Div. Mines Open-File Rept. 5108, 173 p.

175a, Quaternary geology of the Walkerton area, Bruce and Grey Counties: Ontario Div. Mines Misc. Paper 63, p. 111-112.

$1975 \mathrm{~b}$, Quaternary geology of the Woodstock area, southern Ontario: Ontario Div. Mines Geol. Rept. 119, 91 p.

$1975 \mathrm{c}$, Stratigraphy and quantitative analysis of Wisconsinan tills, Brantford-Woodstock area, Ontario, Canada: Colorado Univ. Ph. D. dissert., 253 p.

1976, Quaternary geology of the Sault Ste. Marie area, District of Algoma: Ontario Div. Mines Misc. Paper 67, p. 134-136.

Cowan, W. R., Karrow, P. F., Cooper, A. J., and Morgan, A. V., 1975, Late Quaternary stratigraphy of the Waterloo-Lake Huron area, southwestern Ontario, field trip 7, in P. G. Telford, ed., Field trips guidebook: Geol. Assoc. Canada, Ann. Mtg., Waterloo, Ontario, 1975, p. 180-222.

Cox, D. D., 1959, Some postglacial forests in central and eastern New York State as determined by the method of pollen analysis: New York State Mus. Sci. Service Bull. 377, 52 p.

Crane, H. R., 1956, University of Michigan radiocarbon dates I: Science, v. 124, p. 664-672.

Crane, H. R., and Griffin, J. B., 1958, University of Michigan radiocarbon dates II: Science, v. 127, p. 1098-1105.

1959, University of Michigan radiocarbon dates IV: Radiocarbon, v. 1, p. 173-198.

1962, University of Michigan radiocarbon dates VII: Radiocarbon, v. 4, p. 183-204.

1964, University of Michigan radiocarbon dates IX: Radiocarbon, v. 6, p. 1-24.

1965, University of Michigan radiocarbon dates X: Radiocarbon, v. 7, p. 123-152.

1966, University of Michigan radiocarbon dates XI: Radiocarbon, v. 8, p. 256-285.

1968, University of Michigan radiocarbon dates XII: Radiocarbon, v. 10 , no. 1 , p. $61-114$.

1972, University of Michigan radiocarbon dates XIV: Radiocarbon, v. 14, no. 1, p. 155-194.

Cressey, G. B., 1928, The Indiana sand dunes and shore lines of the Lake Michigan basin: Geographic Soc. Chicago Bull. 8, 80 p.

Cronin, T. M., 1976, An Arctic foraminiferal fauna from Champlain Sea deposits in Ontario: Canadian Jour. Earth Sci., v. 13, p. $1678-1682$. 
1977, Late-Wisconsin marine environments of the Champlain Valley (New York, Quebec): Quaternary Research, v. 7, p. 238-253.

D'Agostino, John, 1957, Glacial Lake Tonawanda, history and development: State Univ. New York at Buffalo, M.A. thesis, $71 \mathrm{p}$.

David, P. P., 1972, Pleistocene deposits northeast of Montreal: Internat. Geol. Cong., 24th, Montreal, 1972, Guidebook for excursion B-04, 14 p.

Deane, R. E., 1946, Pleistocene deposits and beaches of Orillia map-area, Simcoe and Ontario Counties, Ontario: Geol. Survey Canada Paper 46-20, 29 p.

1948, Glacial geology of the Lake Simcoe area: Univ. Toronto, Ontario, $\mathrm{Ph}$. D. dissert., pages unknown.

1950, Pleistocene geology of the Lake Simcoe district, Ontario: Geol. Survey Canada Mem. 256, 108 p.

Deevey, E. S., Gralenski, L. J., and Hoffren, Väinö, 1959, Yale natural radiocarbon measurements IV: Radiocarbon, v. 1, p. 144-172.

Delibrias, G., Guillier, M. T., and Labeyrie, J., 1969, Gif natural radiocarbon measurements III: Radiocarbon, v. 11, no. 2, p. 327-344.

1974, Gif natural radiocarbon measurements VIII; Radiocarbon, v. 16, no. 1, p. 15-94.

Denny, C. S., 1956, Wisconsin drifts in the Elmira region and their possible equivalents in New England: Am. Jour. Sci., v. 254, p. 82-95.

1966, surficial geology of the Plattsburgh area: Empire State Geogram, v. 4, no. 3, p. 6-10.

1967, Surficial geologic map of the Dannemora quadrangle and part of the Plattsburgh quadrangle, New York: U.S. Geol. Survey Geol. Quad. Map GQ-635.

1970, Surficial geologic map of the Mooers quadrangle and part of the Rouses Point quadrangle, Clinton County, New York: U.S. Geol. Survey Misc. Geol. Inv. Map I-630.

1974, Pleistocene geology of the northeast Adirondack region, New York: U.S. Geol. Survey Prof. Paper 786, 50 p.

Denny, C. S., and Lyford, W. H., 1963, Surficial geology and soils of the Elmira-Williamsport region, New York and Pennsylvania, with a section on forest regions and great soil groups, by J. C. Goodlet and W. H. Lyford: U.S. Geol. Survey Prof. Paper 379, 60 p.

Dineen, R. J., 1973, Glacial deposits and geomorphology of the Coeymans-Glenmont area south of Albany, New York: New York Geol. Survey open-file report, $60 \mathrm{p}$.

Dionne, J.-C., Jurdant, M., and Beaubien, J., 1968, Moraines frontales dans le Parc des Laurentides et régions avoisinantes: Annales de l'ACFAS, v. 35, p. 130-131.

Dorr, J. A., Jr., and Eschman, D. F., 1970, Geology of Michigan: Ann Arbor, Univ. Michigan Press, $476 \mathrm{p}$.

Dreimanis, Aleksis, 1954, Geology of the upper Holland watershed, Ontario, in Water, Part 4, of Upper Holland Valley Conservation Report, 1953: Ontario Dept. Plan. and Devel., p. 6-22, 54.

1957, Stratigraphy of the Wisconsin Glacial Stage along the northwestern shore of Lake Erie: Science, v. 126, p. 166-168.

1958, Wisconsin stratigraphy at Port Talbot on the north shore of Lake Erie, Ontario: Ohio Jour. Sci., v. 58, p. 65-84.

1959, Proposed local stratigraphy of the Wisconsin Glacial Stage in the area south of London, southwestern Ontario, in Field Trip Guide: Friends of Pleistocene Geology, Eastern Sec., 22d Reunion, Univ. Western Ontario, London, Ontario, 1959, p. 24-30.

1961, Tills in southern Ontario, in R. F. Legget, ed., Soils in Canada-Geological, pedological, and engineering studies: Royal Soc. Canada Spec. Pub. 3, p 80-96.
1963, Pleistocene geology of the London-St. Thomas and Port Stanley areas: Ontario Dept. Mines Prog. Rept. 1963-2, p. 33-34.

1964a, Pleistocene geology of the London-St. Thomas and Port Stanley areas: Ontario Dept. Mines Prog. Rept. 1964-6, p. 52-53.

1964b, Lake Warren and the Two Creeks interval: Jour. Geology, v. 72, p. 247-250.

1966a, Lake Arkona-Whittlesey and post-Warren radiocarbon dates from "Ridgetown Island" in southwestern Ontario: Ohio Jour. Sci., v. 66, p. 582-586.

$1966 \mathrm{~b}$, The Susaca- Interstadial and the subdivision of the Late-Glacial-A discussion: Geologie en Mijnbouw, v. 45, p. 445-448.

1967a, Pre-Maumee lake stages of Wisconsin ice age in Lake Erie basin, in Great Lakes Research Conference, 10th, Toronto, 1967, Abstracts: p. 33.

1967b, Mastodons, their geologic age and extinction in Ontario, Canada: Canadian Jour. Earth Sci., v. 4, p. 663-675.

1968a, Cary-Port Huron Interstade in eastern North America and its correlatives, in Abstracts for 1967: Geol. Soc. America Spec. Paper 115, p. 259.

1968b, Extinction of mastodons in eastern North AmericaTesting a new climatic-environmental hypothesis: Ohio Jour. Sci., v. 68, p. 257-272.

1969a, Late-Pleistocene lakes in the Ontario and the Erie basins; in Great Lakes Research Conference, 12th, Ann Arbor, Mich., 1969, Proceedings: Michigan Internat. Assoc., Great Lakes Research, p. 170-180.

$1969 \mathrm{~b}$, Surficial geology, Port Stanley map-area, Ontario (40 I/11 west half): Geol. Survey Canada Paper 69-1, pt. A, p. $190-191$.

1970a, Last ice-age deposits in the Port Stanley map-area, Ontario (40 I/11): Geol. Survey Canada Paper 70-1, pt. A, p. $167-169$.

$1970 \mathrm{~b}$, Recession of the Laurentide ice sheet and the significance of the Two Creeks interstadial-Discussion: Am. Quaternary Assoc., Mtg., 1st, Yellowstone Nat. Park, Wyo., and Bozeman, Mont., 1970, Abs., p. 37.

1971, Wisconsin stratigraphy, north shore of Lake Erie, Ontario: Geol. Survey Canada Paper 71-1, pt. A, p. 159-160.

Dreimanis, Aleksis, and Goldthwait, R. P., 1973, Wisconsin glaciations in the Huron, Erie, and Ontario lobes, in R. F. Black, R. P. Goldthwait, and H. B. Willman, eds., The Wisconsinan Stage: Geol. Soc. America Mem. 136, p. 71-106.

Dreimanis, Aleksis, and Karrow, P. F., 1965, Southern Ontario, in Guidebook for field conference G, Great Lakes-Ohio River valley: Internat. Assoc. Quaternary Research Cong., 7th, U.S.A., 1965, p. 90-110.

1972, Glacial history of the Great Lakes-St. Lawrence region, the classification of the Wisconsin(an) Stage, and its correlatives: Internat. Geol. Cong., 24th, Montreal, 1972, Quaternary Geology, sec. 12, p. 5-15.

Dreimanis, Aleksis, and Morgan, A. V., 1975, Differentiation of two late Wisconsin clayey silt tills between the Seaforth moraine and Lake Huron, Ontario: Geol. Soc. America Abs. with Programs, v. 7, no. 6, p. 748.

Dreimanis, Aleksis, Reavely, G. H., Cook, R. J. B., Knox, K. S., and Moretti, F. J., 1957, Heavy mineral studies in tills of southern Ontario and adjacent areas: Jour. Sed. Petrology, v. 27, p. $148-161$.

Dreimanis, Aleksis, and Terasmae, Jaan, 1958, Stratigraphy of Wisconsin glacial deposits of Toronto area, Ontario: Geol. Assoc. Canada Proc., v. 10, p. 119-135. 
Droste, John, Rubin, Meyer, and White, G. W., 1959, Age of marginal Wisconsin drift at Corry, northwestern Pennsylvania: Science, v. 130 , p. 1760.

Durham, Forrest, 1958, Location of the Valley Heads moraine near Tully Center, New York: Geol. Soc. America Bull., v. 69, p. 1319-1321.

Dyck, Willy, and Fyles, J. G., 1962, Geological Survey of Canada radiocarbon dates I: Radiocarbon, v. 4, p. 13-26.

1963, Geological Survey of Canada radiocarbon dates II: Radiocarbon, v. 5, p. 39-55.

1964, Geological Survey of Canada radiocarbon dates III: Radiocarbon, v. 6, p. 167-181.

Dyck, Willy, Fyles, J. G., and Blake, W., Jr., 1965, Geological Survey of Canada radiocarbon dates IV: Radiocarbon, v. 7, p. 24-46.

Dyck, Willy, Lowdon, J. A., Fyles, J. G., and Blake, W., Jr., 1966, Geological Survey of Canada radiocarbon dates V: Radiocarbon, v. 8, p. 96-127.

Ekblaw, G. E., and Athy, L. F., 1925, Glacial Kankakee torrent in northeastern Illinois: Geol. Soc. America Bull., v. 36, p. 417-427.

Elson, J. A., 1962, Pleistocene geology between Montreal and Covey Hill, field trip 7, in T. H. Clark, ed., Guidebook: New England Intercollegiate Geol. Conf., 54th Ann. Mtg., Montreal, 1962, p. 61-66.

1968, Champlain Sea, in R. W. Fairbridge, ed., The encyclopedia of geomorphology: New York, Reinhold Book Corp., p. 116-117.

1969a, Late Quaternary marine submergence of Quebec: Rév. Géographie Montréal, v. 23, p. 247-258.

$1969 \mathrm{~b}$, Radiocarbon dates, Mya arenaria phase of the Champlain Sea: Canadian Jour. Earth Sci., v. 6, p. 367-372.

Epstein, J. B., 1969, Surficial geology of the Stroudsburg quadrangle, Pennsylvania-New Jersey: Pennsylvania Geol. Survey Gen. Geology Rept. G57, 67 p.

Eschman, D. F., and Farrand, W. R., 1970, Glacial history of the glacial Grand Valley, in Guidebook for field trips: Michigan Basin Geol. Soc., East Lansing, Mich., 1970, p. 131-157.

Eschman, D. F., Farrand, W. R., and Evenson, E. B., 1973, Pleistocene geology of the northwestern quarter Southern Peninsula, Michigan, in Michigan Basin Geological Society Guidebook: p. 14-18.

Evans, E. B., 1970, Pleistocene beach ridges of northwestern Pennsylvania: Bowling Green State Univ., Ohio, M.A. thesis, pages unknown.

Evenson, E. B., 1972, Late Pleistocene shorelines and stratigraphic relationships in the Lake Michigan basin: Univ. Michigan Ph. D. dissert., $88 \mathrm{p}$.

1973a, Late Pleistocene shorelines and stratigraphic relations in the Lake Michigan basin: Geol. Soc. America Bull., v. 84, p. 2281-2297.

$1973 \mathrm{~b}$, A reevaluation of the "Valders" limit in the Lake Michigan basin, in E. B. Evenson, D. F. Eschman, and W. R. Farrand, [eds.], The "Valderan" problem, Lake Michigan basin: Friends of the Pleistocene, [Guidebook], Midwest Sec. 22d Ann. Field Conf., Michigan and Wisconsin, 1973, p. 1-29.

Evenson, E. B., and Dreimanis, Aleksis, 1976, Late glacial $(14,000-$ 10,000 years B.P.) history of the Great Lakes region and possible correlations, in D. J. Easterbrook and Vladimir Sibrava, eds., Quaternary glaciations in the Northern Hemisphere, Project 73-1-24, Report no. 3 on the session in Bellingham, Washington, USA, September 1975: IUGS-UNESCO Internat. Geol. Correlation Program, p. 217-239.
Evenson, E. B., Eschman, D. F., and Farrand, W. R., 1973a, Late glacial history of the Pere Marquette River, Mason and Lake Counties, Michigan, in Michigan Basin Geological Society Guidebook, 1973: p. 19-25.

Evenson, E. B., Eschman, D. F., and Farrand, W. R., [eds.], 1973b, The "Valderan" problem, Lake Michigan basin: Friends of the Pleistocene [Guidebook], Midwest Sec., 22d Ann. Field Conf., Michigan and Wisconsin, 1973, 59 p.

Evenson, E. B., Farrand, W. R., and Eschman, D. F., 1974, Late Pleistocene shorelines and stratigraphic relations in the Lake Michigan basin-Reply: Geol. Soc. America Bull., v. 85, p. 661-664.

Evenson, E. B., Farrand, W. R., Eschman, D. F., Mickelson, D. M., and Maher, L. J., 1976, Greatlakean Substage-a replacement for Valderan Substage in the Lake Michigan basin: Quaternary Research, v. 6, p. 411-424.

1978, Reply to comments by P. F. Karrow and R. F. Black: Quaternary Research, v. 9, no. 1, p. 123-129.

Evenson, E. B., and Mickelson, D. M., 1974, A re-evaluation of the lobation and red till stratigraphy and nomenclature in part of eastern Wisconsin, in J. C. Knox, and D. M. Mickelson, eds., Late Quaternary environments of Wisconsin: Wisconsin Geol. and Nat. History Survey, p. 102-117.

Fairbridge, R. W., 1968, Glacial lakes, in R. W. Fairbridge, ed., The encyclopedia of geomorphology: New York, Reinhold Book Corp., p. 444-453.

Fairchild, H. L., 1895a, The kame-moraine at Rochester, New York: Am. Geologist, v. 16, p. 39-51.

1895b, Glacial lakes of western New York: Geol. Soc. America Bull., v. 6, p. 353-374.

$1895 \mathrm{c}$, Lake Newberry the probable successor of Lake Warren: Geol. Soc. America Bull., v. 6, p. 462-466.

1896a, Glacial Genesee lakes: Geol. Soc. America Bull., v. 7, p. $423-452$.

$1896 \mathrm{~b}$, Kame areas in western New York south of Irondequoit and Sodus Bays: Jour. Geology, v. 4, p. 129-159.

1897, Lake Warren shorelines in western New York and the Geneva beach: Geol. Soc. America Bull., v. 8, p. 269-284. 1899a, Glacial waters in the Finger Lakes region of New York: Geol. Soc. America Bull., v. 10, p. 27-68. $1899 b$, Glacial Lakes Newberry, Warren, and Dana in central New York: Am. Jour. Sci., v. 7, p. 249-263.

1902, Pleistocene geology of western New York, report of progress for 1900: New York State Mus., 54th Ann. Rept. and 20th Report of the State Geologist, p. 103-139.

1903, Latest and lowest pre-Iroquois channels between Syracuse and Rome: New York State Mus., 55th Ann. Rept. and Report of the Director, 1901, p. 31-47.

1904, Glacial waters from Oneida to Little Falls: New York State Mus., 56th Ann. Rept. and Report of the Director and State Geologist, 1902, v. 1, p. 17-41.

1907a, Gilbert Gulf (marine waters in the Ontario basin):

Geol. Soc. America Bull., v. 17, p. 712-718.

1907b, Iroquois extinction [abs.]: Science, v. 26, p. 398-399. $1907 \mathrm{c}$, Glacial waters in the Lake Erie basin: New York State Mus. Bull. 106, 86 p.

1909, Glacial waters in central New York: New York State Mus. Bull. 127, 66 p.

1912, The glacial waters in the Black and Mohawk Valleys: New York State Mus. Bull. 160, 47 p.

1913, Pleistocene geology of New York State: Geol. Soc. America Bull., v. 24, p. 133-162. 
1914, Pleistocene marine submergence of the Connecticut and Hudson Valleys: Geol. Soc. America Bull., v. 25, p. 219-242.

1916a, Pleistocene uplift of New York and adjacent territory: Geol. Soc. America Bull., v. 27, p. 235-262.

$1916 \mathrm{~b}$, Post glacial marine waters in Vermont, in Report of the State Geologist on the mineral industries and geology of Vermont, 1915-1916: Vermont Geol. Survey, p. 1-41.

1917, Postglacial features of the upper Hudson valley: New York State Mus. Bull. 195, 22 p.

1918, Post glacial sea-level waters in eastern Vermont, in Report of the State Geologist on the mineral industries and geology of Vermont, 1917-1918: Vermont Geol. survey, p. 52-75.

1919, Pleistocene marine submergence of the Hudson, Champlain, and St. Lawrence Valleys: New York State Mus. Bull. 209-210, 76 p.

1923, The Pinnacle Hills, or the Rochester kame-moraine: Rochester Acad. Sci. Proc., v. 6, p. 141-194.

1926, The Mendon kame area: Rochester Acad. Sci. Proc., v. 6, p. 195-215.

1932a, Closing stages of New York glacial history: Geol. Soc. America Bull., v. 43, p. 603-626.

1932b, New York moraines: Geol. Soc. America Bull., v. 43, p. 627-662.

1932c, New York physiography and glaciology west of the Genesee Valley: Rochester Acad. Sci. Proc., v. 7, p. 97-135.

1934a, Cayuga Valley lake history: Geol. Soc. America Bull., v. 45, p. $233-280$.

1934b, Seneca Valley physiographic and glacial history: Geol. Soc. America Bull., v. 45, p. 1073-1110.

Faltyn, N. E., 1957, Seismic exploration of the Tully Valley overburden: Syracuse Univ., M.S. thesis, 86 p.

Farrand, W. R., 1962, Postglacial uplift in North America: Am. Jour. Sci., v. 260, p. 181-199.

1970, Remarks on glacial and climatic events along the southern margin of the Laurentide ice sheet-Chairman's summary: Am. Quaternary Assoc. Mtg., 1st, Yellowstone Park, Wyo., and Bozeman, Mont., 1970, Abs., p. 43-44.

Farrand, W. R., and Eschman, D. F., 1974, Glaciation of the Southern Peninsula of Michigan-A review: Michigan Acadamician, v. 7, p. 31-56.

Farrand, W. R., and Miller, B. B., 1968, Radiocarbon dates on and depositional environment of the Wasaga Beach (Ontario) marl. deposit: Ohio Jour. Sci., v. 68, p. 235-239.

Farrand, W. R., Zahner, Robert, and Benninghoff, W. S., 1969, Cary-Port Huron interstade-Evidence from a buried bryophyte bed, Cheboygan County, Michigan: Geol. Soc. America Spec. Paper 123, p. 249-262.

Feenstra, B. H., 1972, Quaternary geology of the Welland area: Ontario Div. Mines Misc. Paper 53, p. 157-158.

1973, Quaternary geology of the Dunnville area, southern

Ontario: Ontario Div. Mines Misc. Paper 56, p. 199-201.

1974, Quaternary geology of the Grimsby area, southern Ontario: Ontario Div. Mines Misc. Paper 59, p. 196-198.

1975a, Quaternary geology of the Markdale area, Grey County: Ontario Div. Mines Misc. Paper 63, p. 116-118.

$1975 \mathrm{~b}$, Late Wisconsin stratigraphy in the northern part of the Stratford-Conestogo area, southern Ontario: Univ. Waterloo, Ontario, M.S. thesis, pages unknown.

Flint, R. F., 1947, Glacial geology and the Pleistocene Epoch: New York, John Wiley and Sons, $589 \mathrm{p}$.
1951, Highland centers of former glacial outflow in northeastern North America: Geol. Soc. America Bull., v. 62, p. 21-38.

1953, Probable Wisconsin substages and late-Wisconsin events in the northeastern United States and southeastern Canada: Geol. Soc. America Bull., v. 64, p. 897-920.

1955, Rates of advance and retreat of the margin of the lateWisconsin ice sheet: Am. Jour. Sci., v. 253, p. 249-255.

1956, New radiocarbon dates and late-Pleistocene stratig. raphy: Am. Jour. Sci., v. 245, p. 265-287.

1957, Glacial and Pleistocene geology: New York, John Wiley and Sons, $553 \mathrm{p}$.

1963, Status of the Pleistocene Wisconsin Stage in central North America: Science, v. 139, p. 402-404.

1971, Glacial and Quaternary geology: New York, John Wiley and Sons, $892 \mathrm{p}$.

1976, Development of Quaternary stratigraphy in northeastern United States and adjacent Canada: Quaternary Research, v. 6, p. 395-409.

Flint, R. F., and Gebert, J. A., 1976, Latest Laurentide ice sheetNew evidence from southern New England: Geol. Soc. America Bull., v. 87, p. 182-188.

Flint, R. F., and Rubin, Meyer, 1955, Radiocarbon dates of preMankato events in eastern and central North America: Science, v. 121, p. 649-658.

Forsyth, J. L., 1956a, Glacial geology of Logan and Shelby Counties, Ohio: Ohio State Univ. Ph. D. dissert., 207 p.

$1956 \mathrm{~b}$, Results of research in Roundhead area, Hardin, Logan, Auglaize, and Allen Counties: available from Ohio Geol. Survey, $5 \mathrm{p}$.

1959, Beach ridges of northern Ohio: Ohio Geol. Survey Inf. Circ. 25, $10 \mathrm{p}$.

1960, Correlation of tills exposed in Toledo Edison dam cut, Ohio: Ohio Jour. Sci., v. 60, p. 94-100.

1961, Pleistocene geology, in S. I. Root, Joaquin Rodriguez, and J. L. Forsyth, Geology of Knox County: Ohio Geol. Survey Bull. 59, p. 107-138.

1965, Contribution of soils to the mapping and interpretation of Wisconsin tills in western Ohio: Ohio Jour. Sci., v. 65, p. 220-227.

1966, Glacial map of Licking County, Ohio: Ohio Geol. Survey Rept. Inv. 59.

1967, Glacial geology of the East Liberty quadrangle, Logan and Union Counties, Ohio: Ohio Geol. Survey Rept. Inv. 66.

1969, Evidence for a pre-Maumee lake in northwestern OhioA progress report, in Great Lakes Research Conference, 12th, Ann Arbor, Mich., 1969, Abstracts: p. 61.

1973, Late-glacial and postglacial history of western Lake Erie: Compass, v. 51, p. 16-26.

Fricke, Carl, and Johnson, T. M., 1977, Stratigraphic relationships of tills in central-southern Wisconsin: Geol. Soc. America Abs. with Programs, v. 9, no. 5, p. 596.

Frye, J. C., Glass, H. D., Kempton, J. P., and Willman, H. B., 1969, Glacial tills of northwestern Illimois: Illinois Geol. Survey Circ. $437,45 \mathrm{p}$.

Frye, J. C., and Leonard, A. B., 1953, Definition of time line separating a glacial and interglacial age in the Pleistocene: Am. Assoc. Petroleum Geologists Bull., v. 37, p. 2581-2586.

Frye, J. C., Leonard, A. B., Willman, H. B., Glass, H. D., and Follmer, L. R., 1974, The late Woodfordian Jules Soil and associated molluscan faunas: Illinois Geol. Survey Circ. 486, 11 p. 
Frye, J. C., and Willman, H. B., 1960, Classification of the Wisconsinan Stage in the Lake Michigan glacial lobe: Illinois Geol. Survey Circ. 285, 16 p.

1963, Development of Wisconsinan classification in Illinois related to radiocarbon chronology: Geol. Soc. America Bull., v. 74, p. 501-506.

1970, Rock stratigraphy in the Illinois Pleistocene, in TriState Geological Field Conference, 34th Annual, 1970, Guidebook: DeKalb, Ill., Northern Illinois Univ., Dept. Geology, p. 60-63.

1973, Wisconsinan climatic history interpreted from Lake Michigan lobe deposits and soils, in R. F. Black, R. P. Goldthwait, and H. B. Willman, eds., The Wisconsinan Stage: Geol. Soc. America Mem. 136, p. 135-152.

1975, Quaternary System, in H. B. Willman, and others, Handbook of Illinois stratigraphy: Illinois Geol. Survey Bull. 95, p. 211-239.

Frye, J. C., Willman, H. B., and Black, R. F., 1965, Outline of glacial geology of Illinois and Wisconsin, in H. E. Wright, Jr., and D. G. Frey, eds., The Quaternary of the United States: Princeton, N.J., Princeton Univ. Press, p. 43-61.

Frye, J. C., Willman, H. B., Rubin, Meyer, and Black, R. F., 1968, Definition of Wisconsinan Stage: U.S. Geol. Survey Bull. 1274-E, 22 p.

Fuller, M. L., 1903, The Horseheads outlet of the glacial lakes of central New York [abs.]: Science, v. 17, p. 26.

1914, The geology of Long Island, New York: U.S. Geol. Survey Prof. Paper 82, $230 \mathrm{p}$.

Fullerton, D. S., 1971, The Indian Castle glacial readvance in the Mohawk Lowland, New York, and its regional implications: Princeton Univ. Ph. D. dissert., 270 p.

1974, Multiple tills near Galena, Delaware County, Ohio: Geol. Soc. America Abs. with Programs, v. 6, no. 6, p. 509.

Funk, R. E., Fisher, D. W., and Reilly, E. M., Jr., 1970, Caribou and paleo-Indian in New York State-A presumed association: Am. Jour. Sci., v. 268, p. 181-186.

Funk, R. E., Walters, G. R., Ehlers, W. F., Guilday, J. E., and Connally, G. G., 1970, The archeology of Dutchess Quarry Cave, Orange County, New York: Pennsylvania Archeologist, v. 39 , p. 7-22.

Gadd, N. R., 1955, Pleistocene geology of the Bécancour map-area, Quebec: Illinois Univ. Ph. D. dissert., pages unknown.

1961, Surficial geology of the Ottawa area-Report of progress: Geol. Survey Canada Paper 61-19, 14 p.

1963, Surficial geology of Ottawa map-area, Ontario and Quebec: Geol. Survey Canada Paper 62-16, 4 p.

1964, Moraines in the Appalachian region of Quebec: Geol. Soc. America Bull., v. 75, p. 1249-1254.

1971 , Pleistocene geology of the central St. Lawrence Lowland: Geol. Survey Canada Mem. 359, 153 p.

1976, Quaternary stratigraphy in southern Quebec, in W. C. Mahaney, ed., Quaternary stratigraphy of North America: Stroudsburg, Pa., Dowden, Hutchinson, and Ross, p. 37-50.

1977, Offlap sedimentary sequence in Champlain Sea, Ontario and Quebec: Geol. Survey Canada Paper 77-1, pt. A, p. $379-380$.

Gadd, N. R., LaSalle, P., Dionne, J. C., Shilts, W. W., and McDonald, B. C., 1972, Quaternary geology and geomorphology, southern Quebec, in Guidebook for excursions A44-C44: Internat. Geol. Cong., 24th, Montreal, 1972, 70 p.

Gadd, N. R., McDonald, B. C., and Shilts, W. W., 1972, Deglaciation of southern Quebec: Geol. Survey Canada Paper 71-47, $19 \mathrm{p}$.
Gangloff, Pierre, 1973, Le milieu morphoclimatique tardiaglaciaire dans la région de Montréal: Cahiers Géographié Québec, v. 17, p. 415-448.

1974, Les structures cylindriques et l'évolution géomorphologique d'une plage tardiglaciaire à Saint-Jérôme, Québec: Rév. Géographié Montréal, v. 28, p. 357-373.

1975, Les dépôts Pléistocènes et la genèse des concrétions calcaires au sud-ouest de Montréal, Québec: Rev. Géographié Montréal, v. 29, p. 133-146.

Gauthier, R. C., 1975, The reversal of glacial movement during the deglaciation of the Chaudiere River region, Quebec: Geol. Soc. America Abs. with Programs, v. 7, no. 6, p. 760-761.

Gilliam, J. A., Kapp, R. O., and Bogue, R. D., 1967, A post-Wisconsin pollen sequence from Vestaburg bog, Montcalm County, Michigan: Michigan Acad. Sci., Arts and Letters Papers, v. 52, p. 3-17.

Goldthwait, J. W., 1906, Correlation of the raised beaches on the west side of Lake Michigan: Jour. Geology, v. 14, p. 411-424.

1907, The abandoned shorelines of eastern Wisconsin: Wisconsin Geol. and Nat. History Survey Bull. 17, 134 p.

1908, A reconstruction of water planes of the extinct glacial lakes in the Lake Michigan basin: Jour. Geology, v. 16, p. 459-476.

1910a, An instrumental survey of the shorelines of the extinct Lakes Algonquin and Nipissing in southwestern Ontario: Geol. Survey Canada Mem. 10, 57 p.

$1910 \mathrm{~b}$, Isobases of the Algonquin and Iroquois beaches and their significance: Geol. Soc. America Bull., v. 21, p. 227-248.

Goldthwait, J. W., and Jacobson, R. C., 1909, Preliminary report on measurements of altitude of the Algonquin and Nipissing shorelines in Ontario, July 6-August 11, 1908: Geol. Survey Canada, Summary Rept., 1908, p. 112-114.

Goldthwait, R. P., 1958, Wisconsin-age forests in western Ohio, pt. 1-Age and glacial events: Ohio Jour. Sci., v. 58, p. 209-219.

1959, Scenes in Ohio during the last ice age: Ohio Jour. Sci., v. 59 , p. $193-216$.

1976, Paleosols and Quaternary history of western Ohio [abs.], in W. C. Mahaney, ed., Quaternary stratigraphy of North America: Stroudsburg, Pa., Dowden, Hutchinson, and Ross, p. 159-160.

Goldthwait, R. P., Dreimanis, Aleksis, Forsyth, J. L., Karrow, P. F., and White, G. W., 1965, Pleistocene deposits of the Erie lobe, in H. E. Wright, Jr., and D. G. Frey, eds., The Quaternary of the United States: Princeton, N.J., Princeton, Univ. Press, p. 85-97.

Goldthwait, R. P., [and Rosengreen, T.], 1969, Till stratigraphy from Columbus southwest to Highland County, Ohio, field trip 2, in Guidebook: Geol. Soc. America, North-Central Sec., 3d Ann. Mtg., Columbus, Ohio, 1969, p. 2-1 to 2-17.

Goldthwait, R. P., White, G. W., and Forsyth, J. L., 1961, Glacial map of Ohio [revised in part, 1967] U.S. Geol. Survey Misc. Geol. Inv. Map I-316.

Gooding, A. M., 1971, Character of late Wisconsin tills in eastern Indiana: Indiana Geol. Survey Bull. 49, 28 p.

Gravenor, C. P., 1957, Surficial geology of the Lindsay-Peterborough area, Ontario: Geol. Survey Canada Mem. 228, 60 p.

Gravenor, C. P., and Stupavsky, M., 1976, Magnetic, physical, and lithologic properties and age of till exposed along the east coast of Lake Huron, Ontario: Canadian Jour. Earth Sci., v. 13, p. $1655-1666$.

Gregory, J. F., 1956, The Pleistocene geology of Crawford County, Ohio: Ohio State Univ. M.S. thesis, 87 p. 
Gregory, W. M., 1912, Geological report on Arenac County: Michigan Geol. Survey Pub. 11, Geol. Ser. 8, 146 p.

Gross, D. L., Lineback, J. A., White, W. A., Ayer, N. J., Collinson, Charles, and Leland, H. V., 1970, Preliminary stratigraphy of unconsolidated sediments from the southwestern part of Lake Michigan: Illinois Geol. Survey Environmental Geology Note $30,20 \mathrm{p}$.

Gwyn, Q. H. J., 1971, Heavy mineral assemblages in tills and their use in distinguishing glacial lobes in the Great Lakes region: Univ. Western Ontario, Ontario, Ph. D. dissert., 192 p.

1972, Quaternary geology of the Alliston-Newmarket area, southern Ontario: Ontario Div. Mines Misc. Paper 53, p. 144-147.

$1975 \mathrm{a}$, On the origin of the Oak Ridges and Orangeville moraines: Geol. Soc. America Abs. with Programs, v. 7, no. 6, p. 771.

$1975 \mathrm{~b}$, Quaternary geology and granular resources of the Oak Ridges moraine in the regional municipality of Durham, southern Ontario: Ontario Div. Mines Misc. Paper 63, p. 124-125.

$1975 \mathrm{c}$, Quaternary geology of the Dundalk area, southern Ontario: Ontario Div. Mines open-file rept. 5132, 138 p.

Gwyn, Q. H. J., and Lohse, H., 1973, Quaternary geology of the Alexandria area, southern Ontario: Ontario Div. Mines Misc. Paper 56, p. 181-184.

Gwyn, Q. H. J., and Thibault, J. J. L., 1974, Quaternary geology of the Hawkesbury, Huntingdon, Lachute, and Vaudreuil areas: Ontario Div. Mines Misc. Paper 59, p. 178-182.

Hand, B. M., and Muller, E. H., 1972, Syracuse channels; evidence of a catastrophic flood, in J. McLelland, ed., Field trip guidebook: New York State Geol. Assoc., 44th Ann. Mtg., Syracuse, N.Y., 1972, p. I1-I12.

Hanson, L. S., and Caldwell, D. W., 1977, Late Wisconsin moraines in northwestern Maine which postdate the marine transgression into the St. Lawrence Valley: Geol. Soc. America Abs. with Programs, v. 9, no. 3, p. 272.

Harris, S. A., 1967, Origin of part of the Guelph drumlin field and the Galt and Paris moraines, Ontario-A reinterpretation: Canadian Geographer, v. 11, p. 16-34.

1970, The Waterloo kame-moraine, Ontario, and its relationship to the Wisconsin advances of the Erie and Simcoe ice lobes: Zeitschr. Geomorphologie, v. 14, p. 487-509.

Harrison, J. E., 1970, Deglaciation and proglacial drainage evolution-North Bay-Mattawa region, Ontario, in Great Lakes Research Conference, 13th, Ann Arbor, Mich., 1970, Proceedings: p. 756-767.

1972, Quaternary geology of the North Bay-Mattawa region: Geol. Survey Canada Paper 71-26, $37 \mathrm{p}$.

1977, Coastal studies in the Ottawa area: Geol. Survey Canada Paper 77-1, pt. A, p. 59-60.

Heath, C. P. M., 1963, The mineralogy of tills in the Grand River glacial lobe in northeastern Ohio: Illinois Univ. M.S. thesis, $199 \mathrm{p}$.

Held, E. R., and Kapp, R. O., 1969, Pollen analysis at the Thaller mastodon site, Gratiot County, Michigan: Michigan Botanist, v. 8, p. 3-10.

Henderson, E. P., 1967, Surficial geology north of the St. Lawrence River, Kingston to Prescott, in S. E. Jenness, ed., Geology of parts of eastern Ontario and western Quebec: Geol. Assoc. Canada, Guidebook, Kingston, Ontario, 1967, p. 199-207.

1969a, Limit of Champlain Sea, eastern Ontario Lowland: Geol. Survey Canada Paper 69-1, pt. A, p. 202. 1969b, Quaternary geology, Kingston (north half), Ontario: Geol. Survey Canada Paper 69-1, pt. A, p. 202-203.

1971, Quaternary geology, Kingston, Ontario: Geol. Survey Canada Paper 71-1, pt. A, p. 167-168.

1973a, Surficial geology of Kingston (north half) map-area, Ontario: Geol. Survey Canada Paper 72-48, 6 p.

1973b, Quaternary geology, Halburton-Burleigh Falls area, Ontario: Geol. Survey Canada Paper 73-1, pt. A, p. 200-202.

Herdendorf, C. E., 1968, Sedimentation studies in the south shore reef area of western Lake Erie, in Great Lakes Research Conference, Milwaukee, Wis., 1968, Proceedings: Internat. Assoc. Great Lakes Research, p. 188-205.

Herpers, Henry, 1961, The Ogdensburg-Culvers Gap recessional moraine and glacial stagnation in New Jersey: New Jersey Geol. Survey Geol. Rept. 6, 16 p.

Hillaire-Marcel, Claude, 1973, Commentaires sur la phase à $M y a$ arenaria de la Mer de Champlain [abs.]: Le Quaternaire du Québec, 2d Colloque, Montreal, Résumés des Communications, p. 11.

1974a, La déglaciation au nord-ouest de Montréal-données radiochronologiques et faits stratigraphiques: Rev. Géographie Montréal, v. 28, p. 407-417.

1974b, Etat actuel des connaissances sur le relèvement glacio-isostatique dans la région de Montréal (Quebec) entre moins 13,000 et moins 9,000 ans: Acad. Sci. Comptes Rendus (Paris), v. 278, ser. D, p. 1939-1942.

Hillaire-Marcel, Claude, and Occhietti, Serge, 1977, Fréquence des datations au ${ }^{14} \mathrm{C}$ de faunes post-glaciaires de l'Est du Canada et variations paléoclimatiques: Palaeogeography, Paleoclimatology, Palaeoecology, v. 21, p. 17-54.

Hillaire-Marcel, Claude, Prichonnet, G., and De Boutray, B., 1974, Les faciès du Pléistocène marin des collines d'Oka, Quebec: Canadian Naturalist, v. 101, p. 781-802.

Hills, G. A., Richards, N. R., and Morwick, F. F., 1944, Soil survey of Carleton County, Province of Ontario: Ontario Soil Survey Rept. 7, 103 p.

Hitchcock, C. H., 1906, The Champlain deposits of northern Vermont, in Report of the State Geologist on the mineral industries and geology of certain areas of Vermont, 1905-1906: Vermont Geol. survey, p. 236-253.

1910, Surficial geology of the Champlain basin, in Report of the State Geologist on the mineral industries and geology of certain areas of Vermont, 1909-1910: Vermont Geol. Survey, p. 199-212.

Hobbs, W. H., 1911, The late glacial and post-glacial uplift of the Michigan basin: Michigan Geol. Sürvey Pub. 5, Geol. Ser. 3, p. 11-68.

Hobson, G. D., Herdendorf, C. E., and Lewis, C. F. M., 1969, High resolution reflection seismic survey in western Lake Erie, in Great Lakes Research Conference, 12th, Ann Arbor, Mich., 1969, Proceedings: Internat. Assoc. Great Lakes Research, p. 210-224.

Hollands, G. C., 1973, History of deglaciation of southern Erie County, western New York: Geol. Soc. America Abs. with Programs, v. 5, no. 2, p. 178-179.

1975, Surficial geology of the Colden quadrangle, western New York: Massachusetts Univ., M.S. thesis, pages unknown.

Holmes, C. D., 1927, Special glacial features of the Cazenovia quadrangle: Syracuse Univ., M.S. thesis, 55 p.

1939, Pleistocene geology of the region south of Syracuse, New York: Yale Univ., Ph. D. dissert., 187 p.

1952, Drift dispersion in west-central New York: Geol. Soc. America Bull., v. 63, p. 993-1010. 
1959, Late glacial ice-margin alignments in western New York [abs.]: Geol. Soc. America Bull., v. 70, p. 1619.

Horton, J. H., 1961, Glacial lake shorelines in northern Wentworth County, Ontario: McMaster Univ. B.A. thesis, pages unknown.

Hough, J. L., 1953, Final report on the project Pleistocene chronology of the Great Lakes region: Urbana, Ill., Illinois Univ., Office of Naval Research Contract No. N6ori-07133, Project NR-018-122, 108 p.

1955, Lake Chippewa, a low stage of Lake Michigan indicated by bottom sediments: Geol. Soc. America Bull., v. 66, p. 957-968.

1958, Geology of the Great Lakes: Urbana, Ill., Illinois Univ. Press, 313 p.

1962, Lake Stanley, a low stage of Lake Huron indicated by bottom sediments: Geol. Soc. America Bull., v. 73, p. 613-619.

1963, The prehistoric Great Lakes of North America: Am. Scientist, v. 51, p. 84-109.

1966, Correlation of glacial lake stages in the Huron-Erie and Michigan basins: Jour. Geology, v. 74, p. 62-77.

1968, Great Lakes (North America), in R. W. Fairbridge, ed., The encyclopedia of geomorphology: New York, Reinhold Book Corp., p. 499-506.

1969, A new Huron basin lake level-and outlet upliftcurve, in Abstracts for 1968: Geol. Soc. America Spec. Paper 121, p. 141-142.

Hunter, A. F., 1902, The Algonquin shore line in Simcoe County, Ontario: Geol. Survey Canada, Suminary Rept. for 1902, p. 281-304.

Isachsen, Y. W., 1975a, Possible evidence for contemporary doming of the Adirondack Mountains, New York, and suggested implications for regional tectonics and seismicity: Tectonophysics, $v$. 29, p. $169-181$.

$1975 \mathrm{~b}$, Contemporary vertical movements associated with the Adirondack Mountains dome, an anomalous uplift on the North American craton: Geol. Soc. America Abs. with Programs, v. 7, no. 7, p. 1127-1128.

Isachsen, Y. W., and Wold, R. J., 1977, Geodetic, geological, and geophysical evidence for Holocene vertical movements in the Adirondack region, New York: Geol. Soc. America Abs. with Programs, v. 9, no. 3, p. 278-279.

Ives, P. C., Levin, Betsy, Robinson, R. D., and Rubin, Meyer, 1964, U.S. Geological Survey radiocarbon dates VII: Radiocarbon, v. 6, p. 37-76.

Jardine, W. G., 1972, Glacial readvances in the context of Quaternary classification: Internat. Geol. Cong., 24th, Montreal, 1972, Quaternary Geology, Sec. 12, p. 48-54.

Johnson, G. H., Schneider, A. F., and Ulrich, H. P., 1965, Glacial geology and soils of the area around Lake Maxinkuckee: Indiana Acad. Sci., Field Trip Guidebook, 27 p.

Johnson, W. H., 1976, Quaternary stratigraphy in Illinois-Status and current problems, in W. C. Mahaney, ed., Quaternary stratigraphy of North America: Stroudsburg, Pa., Dowden, Hutchinson, and Ross, p. 161-196.

Johnston, W. A., 1916a, The Trent Valley outlet of Lake Algonquin and the deformation of the Algonquin water-plane in the Lake Simcoe district, Ontario: Geol. Survey Canada Mus. Bull. 23, $27 \mathrm{p}$.

1916b, Late Pleistocene oscillations of sea-level in the Ottawa valley: Geol. Survey Canada Mus. Bull. 24, Geol. Ser. 33, 14 p.

1917, Pleistocene and Recent deposits in the vicinity of Ottawa, with a description of the soils: Geol. Survey Canada Mem. 101, 69 p.

Kaiser, R. F., 1957, The surficial geology of the southeastern segment of the Lake Ontario till plain: Syracuse Univ. Ph. D. dissert., pages unknown.
Karrow, P. F., 1957, Pleistocene geology of the Grondines maparea, Quebec: Illinois Univ. Ph. D. dissert., 95 p.

1961, The Champlain Sea and its sediments, in R. F. Leggett, ed., Soils in Canada-Geological, pedological, and engineering studies: Royal Soc. Canada Special Pub. 3, p. 97-108.

1963, Pleistocene geology of the Hamilton-Galt area: Ontario Dept. Mines Geol. Rept. 16, 68 p.

1966, The Waterloo interlobate area: Geol. Survey Canada Paper 66-1, p. 155-156.

1967a, Tills of the Stratford-Conestogo area: Geol. Survey Canada Paper 67-1, pt. A, p. 147-148.

$1967 \mathrm{~b}$, Pleistocene geology of the Scarborough area: Ontario Dept. Mines Geol. Rept. 46, 108 p.

1968a, Surficial geology, Stratford-Conestogo area: Geol. Survey Canada Paper 68-1, pt. A, p. 169-171.

1968b, Pleistocene geology of the Guelph area: Ontario Dept. Mines Geol. Rept. 61, 38 p.

$1969 \mathrm{a}$, Character and variations in multiple-till sequences in the Waterloo interlobate area of Ontario: Geol. Soc. America Abs. with Programs for 1969, pt. 6, North-Central Sec., p. 25. $1969 \mathrm{~b}$, Stratigraphic studies in the Toronto Pleistocene: Geol. Assoc. Canada Proc., v. 20, p. 4-16.

1970, Pleistocene geology of the Thornhill area: Ontario Dept. Mines Industrial Minerals Rept. 32, $51 \mathrm{p}$.

1971, Quaternary geology of the Stratford-Conestogo area, Ontario: Geol. Survey Canada Paper 70-34, 11 p.

1973a, Quaternary geology of the St. Mary's area, southern Ontario: Ontario Div. Mines Misc. Paper 56, p. 196-198.

1973b, The Waterloo k .me-moraine-A discussion: Zeitschr. Geomorphologie, v. 17, p. 126-133.

1974a, Till stratigraphy in parts of southwestern Ontario: Geol. Soc. America Bull., v. 85, p. 761-768.

1974b, Quaternary geology of the St. Mary's area, southern Ontario: Ontario Div. Mines Open-File Rept. 5116, 130 p.

1978, Comment on "Greatlakean Substage: a replacement for Valderan Substage in the Lake Michigan basin" by E. B. Evenson, W. R. Farrand, D. F. Eschman, D. M. Mickelson, and L. J. Maher: Quaternary Research, v. 9, no. 1, p. 116-118.

Karrow, P. F., Anderson, T. W., Clarke, A. H., Delorme, L. D., and Sreenivasa, M. R., 1975, Stratigraphy, paleontology, and age of Lake Algonquin sediments in southwestern Ontario, Canada: Quaternary Research, v. 5, p. 49-87.

Karrow, P. F., Clarke, J. R., and Terasmae, J., 1961, The age of Lake Iroquois and Lake Ontario: Jour. Geology, v. 69, p. 659667.

Karrow, P. F., and Morgan, A. V., 1975, Quaternary stratigraphy of the Toronto area, field trip 6, in P. G. Telford, ed., Field trips guidebook: Geol. Assoc. Canada, Ann. Mtg., Waterloo, Ontario, 1975, p. 161-179.

Kelley, G. C., 1975a, Deglaciation of the Housatonic region in northwestern Connecticut: Geol. Soc. America Abs. with Programs, v. 7, no. 1, p. 83.

$1975 \mathrm{~b}$, The glacial geology of the Housatonic River region in northwestern Connecticut, trip B-8, in N. M. Ratcliffe, ed., Guidebook for field trips in western Massachusetts, northern Connecticut, and adjacent areas of New York-New England Intercollegiate Geol. Conf., 67th Ann. Mtg., 1975: p. 235-242.

Kelley, R. W., and Farrand, W. R., 1967, The glacial lakes around Michigan: Michigan Geol. Survey Bull. 4, 21 p.

Kindle, E. M., and Taylor, F. B., 1913, Description of the Niagara quadrangle: U.S. Geol. Survey Geol. Atlas, Folio 190, 26 p.

Kirkland, J. T., 1968, Location of the Valley Heads moraine in the Tully Valley region, New York: State Univ. New York at Cortland, M.S. thesis, pages unknown. 
1970, Deglaciation of the eastern Finger Lakes region, trip F, in W. G. Heaslip, ed., Field trip guidebook: New York State Geol. Assoc., 42d Ann. Mtg., Syracuse, N.Y., 1970: p. F1-F9. 1973a, Glacial geology of the western Catskills: State Univ. New York at Binghamton, Ph. D. dissert., $88 \mathrm{p}$.

$1973 \mathrm{~b}$, Glaciation of the western Catskill Mountains, in D. R. Coates, ed., Glacial geology of the Binghamton-western Catskill region: State Univ. New York at Binghamton, Geomorphology Pubs. Contr. 3, p. 56-68.

Knox, K. S., 1952, The differentiation of the glacial tills along the north shore of Lake Erie; Univ. Western Ontario, Ontario, M.S. thesis, $64 \mathrm{p}$.

Kocurko, M. J., 1968, The paleoecology of a Late Pleistocene lake, southeastern Wisconsin: Univ. Wisconsin at Milwaukee M.S. thesis, $62 \mathrm{p}$.

Krall, D. B., 1966, Fluvioglacial drainage between Skaneateles and Syracuse, New York: Syracuse Univ., M.S. thesis, 158 p.

1972, Till stratigraphy and Olean ice retreat in east-central New York: Rutgers Univ., Ph. D. dissert., 95 p.

1975, Glacial geology of the Appalachian Plateau south of Utica, New York: Geol. Soc. America Abs. with Programs, v. 7, no. 1, p. 86.

1977, Late Wisconsinan ice recession in east-central New York: Geol. Soc. America Bull., v. 88, p. 1697-1710.

Krueger, H. W., and Weeks, C. F., 1966, Geochron Laboratories, Inc. radiocarbon measurements II: Radiocarbon, v. 8, p. 142160.

Kunkle, G. R., 1963, Lake Ypsilanti-A probable late Pleistocene low-lake stage in the Erie basin: Jour. Geology, v. 71, p. 72-75.

LaFleur, R. G., 1960, Pleistocene geology of the Troy, New York, quadrangle: Rensselaer Polytechnic Inst., Ph. D. dissert., pages unknown.

1961, Glacial features in the vicinity of Troy, New York, trip A, in R. G. LaFleur, ed., Guidebook to field trips: New York State Geol. assoc., 33d Ann. Mtg., Troy, N. Y., 1961, p.A1-A21.

1965a, Glacial lake sequences in the eastern Mohawk-northern Hudson region, trip C, in P. C. Hewitt, and L. M. Hall, eds., Guidebook to field trips in the Schenectady area: New York State Geol. Assoc., 37th Ann. Mtg., Schenectady, N. Y., 1965, p. C1-C23.

1965b, Ice stagnation deposits in the northern Hudson Lowland, in Guidebook for field conference A, New England-New York State, Pt. 2: Internat. Assoc. Quaternary Research Cong., 7th, U.S.A., 1965, p. 39-47.

1965c, Glacial geology of the Troy, N. Y., quadrangle: New York State Mus. and Sci. Service Map and Chart Ser. 7, 22 p.

1968, Glacial Lake Albany, in R. W. Fairbridge, ed., The encyclopedia of geomorphology: New York, Reinhold Book Corp., p. 455-456.

1969, Glacial geology of the Schoharie Valley, trip 5, in J. M. Bird, ed., Guidebook for field trips in New York, Massachusetts, and Vermont: New England Intercollegiate Geol. Conf., 61st Ann. Mtg., Albany, N.Y., 1969, 20 p.

1975, Sequence of events in the eastern Mohawk Lowland prior to waning of Lake Albany: Geol. Soc. America Abs. with Programs, v. 7, no. 1, p. 87.

LaMarche, R. Y., 1971, Northward moving ice in the Thetford Mines area of southern Quebec: Am. Jour. Sci., v. 271, p. 383-388.

1974, Southeastward, northward, and westward ice movement in the Asbestos area of southern Quebec: Geol. Soc. America Bull., v. 85, p. 465-470.

Lane, A. C., 1908, Summary of the surface geology of Michigan: Michigan Geol. Survey Rept. for 1907, p. 89-143.
Langey, E. J., 1952, Unconsolidated sediments in the Black River area of New York State: Syracuse Univ. Ph. D. dissert., 194 p.

Larsen, F. D., 1975, Movement of late Wisconsin ice in central Vermont as shown by the Barre Granite indicator fan: Geol. Soc. America Abs. with Programs, v. 7, no. 1, p. 87-88.

LaSalle, Pierre, 1966, Late Quaternary vegetation and glacial history in the St. Lawrence Lowlands, Canada: Leidse Geol. Meded., pt. 38, p. 91-128.

1970, Notes on the St-Narcisse morainic system north of Quebec City: Canadian Jour. Earth Sci., v. 7, no. 2, pt. 1, p. 516-521.

1973, Preliminary report on the Quaternary geology near Quebec City: Geol. Soc. America Abs. with Programs, v. 5, no. 2, p. 187.

LaSalle, Pierre, and EIson, J. A., 1975, Emplacement of the St. Narcisse moraine as a climatic event in eastern Canada: Quaternary Research, v. 5, p. 621-625.

LaSalle, Pierre, Hardy, L., and Poulin, P., 1972, An ice frontal position in the northwest part of the Parc des Laurentides and northeast of Quebec City: Quebec Dept. Nat. Resources Rept. S-135, 8 p.

LaSalle, Pierre, and Rondot, Jehan, 1967, New ${ }^{14} \mathrm{C}$ dates from the Lac St-Jean area, Quebec: Canadian Jour. Earth Sci., v. 4, p. 568-571.

Lasca, N. P., 1970a, The Pleistocene geology of southeastern Wisconsin, an introduction, in R. F. Black, and others, The Pleistocene geology of southern Wisconsin: Wisconsin Geol. and Nat. HIstory Survey Inf. Circ. 15, pt. B, p. B1-B7.

$1970 \mathrm{~b}$, Pleistocene geology from Milwaukee to the Kettle Interlobate Moraine, in R. F. Black, and others, The Pleistocene geology of southern Wisconsin: Wisconsin Geol. and Nat. History Survey Inf. Circ. 15, pt. C, p. C1-C14.

Laudenslager, Richard, 1970, New evidence concerning the Valley Heads problem [abs.], in W. G. Heaslip, ed., Field trip guidebook: New York State Geol. Assoc., 42d Ann. Mtg. Syracuse, N.Y., 1970, Tech. Sess., p. TS-6.

Laverdière, Camille, and Courtemache, Albert, 1959, Généralitiés et traits d'ensemble, [Pt.] 1 of La geomorphologie glaciaire de la région du Mont Tremblant: Rev. Canadienne de Géographie, v. 13 , p. 102-134.

1960, La région de St-Faustin-St-Jovite, [Pt.] 2 of La géomorphologie glaciaire de la région du Mont-Tremblant: Cahiers géographie Québec, no. 9, p. 5-32.

Lee, H. A., 1950, Pleistocene geology of Fenelon Township, Victoria County, Ontario: Geol. Survey Canada Paper 50-36, 14 p.

1962, Surficial geology of Rivière-du-Loup-Trois Pistoles area, Quebec: Geol. Survey Canada Paper 61-32, 2 p.

1963a, Pleistocene glacial-marine relations, Trois-Pistoles, Quebec, in Abstracts for 1962: Geol. Soc. America Spec. Paper 73, p. 195.

1963b, Field trip guide: Friends of the Pleistocene, Eastern Sec., 26th Ann. Reunion, Rivière-du-Loup, Québéc, 1963: Geol. Survey Canada, $29 \mathrm{p}$.

Leighton, M. M., 1933, The naming of the subdivisions of the Wisconsin Glacial Age: Science, v. 77, p. 168.

1957, The Cary-Mankato-Valders problem: Jour. Geology, v. 65 , p. $108-111$.

1960, The classification of the Wisconsin Glacial Stage of north central United States: Jour. Geology, v. 68, p. 529-552.

Leighton, M. M., and Willman, H. B., 1953, Basis of subdivisions of Wisconsin Glacial Stage in northeastern Illinois, in Itinerary: Illinois Geol. Survey and Indiana Geol. Survey Joint Geol. Field Conf., 1953, p. 1-73.

Leverett, Frank, 1889, Raised beaches of Lake Michigan: Wisconsin Acad. Sci. Trans., v. 7, p. 177-192. 
1892 , On the correlation of moraines with raised beaches of Lake Erie: Am. Jour. Sci., v. 43, p. 281-301.

1895 , On the correlation of New York moraines with raised beaches of Lake Erie: Am. Jour. Sci., v. 50, p. 1-20.

1897, The Pleistocene features and deposits of the Chicago area: Chicago Acad. Sci. Bull. 2, 86 p.

1898 , Correlation of moraines with beaches on the border of Lake Erie: Am. Geologist, v. 21, p. 195-199.

1899, The Illinois glacial lobe: U.S. Geol. Survey Mon. 38, $817 \mathrm{p}$.

1902a, Surface geology of Alcona County, Michigan: Michigan Geol. Survey Rept. for 1901, p. 35-64.

$1902 b$, Glacial formations and drainage features of the Erie and Ohio basins: U.S. Geol. Survey Mon. 41, 802 p.

1904, Glacial geology of the Grand Rapids area, Michigan: Michigan Geol. Survey, v. 9, pt. 2, p. 56-59.

1905, Review of the glacial geology of the Southern Peninsula of Michigan: Michigan Acad. Sci. Rept. 6, p. 100-110.

1910, An outline of the history of the Great Lakes: Michigan Acad. Sci. Rept. 12, p. 19-42.

1911, Surface geology of the Northern Peninsula of Michigan, with notes on agricultural conditions and water power: Michigan Geol. Survey Pub. 7, Geol. Ser 5, 91 p.

1912, Surface geology and agricultural conditions of the Southern Peninsula of Michigan: Michigan Geol. Survey Pub. 9 Geol. Ser. 7, 144 p.

1914, Notes concerning the features of St. Joseph Island, Lake Huron, Ontario: Geol. Survey Canada, Summary Rept. for 1912, p. 271-274.

1917, Surface geology and agricultural conditions of Michigan: Michigan Geol. Survey Pub. 25 Geol. Ser. 21, 223 p.

1929, Moraines and shorelines of the Lake Superior region: U.S. Geol. Survey Prof. Paper 154-A, 72 p.

1931a, Quaternary System, in H. P. Cushing, Frank Leverett, and F. R. Van Horn, Geology and mineral resources of the Cleveland district, Ohio: U.S. Geol. Survey Bull. 818, p. 57-81.

1931b, Quaternary Period, in H. P. Cushing, Frank Leverett, and F. R. Van Horn, Geology and mineral resources of the Cleveland district, Ohio: U.S. Geol. Survey Bull. 818, p. 95-104.

1939, Correlations of beaches with moraines in the Huron and Erie basins: Am. Jour. Sci., v. 237, p. 456-475.

Leverett, Frank, and Taylor, F. B., 1915, The Pleistocene of Indiana and Michigan and the history of the Great Lakes: U.S. Geol. Survey Mon. 53, 529 p.

Levin, Betsy, Ives, P. C., Oman, C. L., and Rubin, Meyer, 1965, U.S. Geological Survey radiocarbon dates VIII: Radiocarbon, v. 7, p. 372-398.

Lewis, C. F. M., 1966, Sedimentation studies of unconsolidated deposits in the Lake Erie basin: Univ. Toronto, Ontario, Ph. D. dissert., $134 \mathrm{p}$.

1968, Late Quaternary events on Manitoulin Island, in B. A. Liberty, ed., The geology of Manitoulin Island: Michigan Basin Geol. Soc., Ann. Field Excursion Guidebook, 1968, p. 60-67.

1969, Late Quaternary history of lake levels in the Huron and Erie basins, in Great Lakes Research Conference, 12th, Ann Arbor, Mich., 1969, Proceedings: Internat. Assoc. Great Lakes Research, p. 250-270.

1970, Recent uplift of Manitoulin Island, Ontario: Canadian Jour. Earth Sci., v. 7, p. 665-675.

Lewis, C. F. M., Anderson, T. W., and Berti, A. A., 1966, Geological and palynological studies of early Lake Erie deposits, in Great Lakes Research Conference, 9th, Chicago, 1966, Proceedings: Michigan Univ. Great Lakes Research Div. Pub. 15, p. 176-191.
Lewis, C. F. M., Wootton, A. E., and Davis, J. B., 1972, Stratigraphic and engineering studies of unconsolidated sediments in central Lake Erie near Erieau, Ontario: Geol. Survey Canada Paper 73-1, pt. A, p. 205-210.

Libby, W. F., 1954, Chicago radiocarbon dates IV: Science, v. 119, p. 135-140.

1955, Radiocarbon dating [2d ed.]: Chicago Univ. Press, $175 \mathrm{p}$.

Lineback, J. A., Ayer, N. J., and Gross, D. L., 1970, Stratigraphy of unconsolidated sediments in the southern part of Lake Michigan: Illinois Geol. Survey Environmental Geology Note 35, $35 \mathrm{p}$.

Lineback, J. A., Gross, D. L., and Meyer, R. P., 1972, Geologic cross sections derived from seismic profiles and sediment cores from southern Lake Michigan: Illinois Geol. Survey Environmental Geology Note 54, $43 \mathrm{p}$.

1974, Glacial tills under Lake Michigan: Illinois Geol. Survey Environmental Geology Note 69, 48 p.

Lineback, J. A., Gross, D. L., Meyer, R. P., and Unger, W. L., 1971, High-resolution seismic profiles and gravity cores of sediments in southern Lake Michigan: Illinois Geol. Survey Environmental Geology Note 47, 41 p.

Løken, O. H., and Leahy, E. J., 1964, Small moraines in southeastern Ontario: Canadian Geographer, v. 8, p. 10-21.

Lortie, Guy, 1975, Direction d'ecoulement des glaciers du Pleistocene des cantons de l'est, Quebec: Geol. Survey Canada Paper 75-1, pt. A, p. 415-416.

Lougee, R. J., 1953, A chronology of postglacial time in eastern North America: Sci. Monthly, p. 259-276, May.

Lowdon, J. A., and Blake, W., Jr., 1968, Geological Survey of Canada radiocarbon dates VII: Radiocarbon, v. 10, p. 207-245. 1970, Geological Survey of Canada radiocarbon dates IX: Radiocarbon, v. 12, p. 46-86.

1973, Geological Survey of Canada radiocarbon dates XIII: Geol. Survey Canada Paper 73-7,61 p.

1975, Geological Survey of Canada radiocarbon dates XV: Geol. Survey Canada Paper 75-7, 32 p.

1976, Geological Survey of Canada radiocarbon dates XVI: Geol. Survey Canada Paper 76-7, 21 p.

Lowdon, J. A., Fyles, J. G., and Blake, W., Jr., 1967, Geological Survey of Canada radiocarbon dates VI: Radiocarbon, v. 9, p. 156-197.

Lowdon, J. A., Robertson, I. M., and Blake, W., Jr., 1971, Geological Survey of Canada radiocarbon dates XI: Radiocarbon, v. 13, no. 2, p. 255-324.

Lowdon, J. A., Wilmeth, R., and Blake, W., Jr., 1972, Geological Survey of Canada radiocarbon dates XII: Geol. Survey Canada Paper 72-7, 26 p.

Luittig, Gerd, 1958, Eiszeit-Stadium-Phase-Staffel-Eine nomenklatorische Betrachtung: Geol. Jahrb., v. 76, p. 235-260.

1965, Interglacial and interstadial periods: Jour. Geology, v. 73, p. 579-591.

McCallum, K. J., 1955, Carbon-14 age determinations at the University of Saskatchewan: Royal Soc. Canada Trans., v. 49, sec. 4, p. 31-35.

McCallum, K. J., and Dyck, Willy, 1960, University of Saskatchewan radiocarbon dates II: Radiocarbon, v. 2, p. 73-81.

McCallum, K. J., and Wittenburg, J., 1965, University of Saskatchewan radiocarbon dates IV: Radiocarbon, v. 7, p. 229-235.

MacClintock, Paul, 1954a, Pleistocene geology of the St. Lawrence Lowland: New York State Mus. and Sci. Service, Rept. Inv. 10, $20 \mathrm{p}$.

1954b, Leaching of Wisconsin gravels in eastern North America: Geol. Soc. America Bull., v. 65, p. 369-384. 
1958, Glacial geology of the St. Lawrence Seaway and power projects: New York State Mus. and Sci. Service, 26 p.

MacClintock, Paul, and Dreimanis, Aleksis, 1964, Reorientation of till fabric by overriding glacier in the St. Lawrence valley: Am. Jour. Sci., v. 262, p. 133-142.

MacClintock, Paul, and Stewart, D. P., 1965, Pleistocene geology of the St. Lawrence Lowland: New York State Mus. and Sci. Service Bull. 394, $152 \mathrm{p}$.

MacClintock, Paul, and Terasmae, Jaan, 1960, Glacial history of Covey Hill: Jour. Geology, v. 68, p. 232-241.

McDonald, B. C., 1967, Pleistocene events and chronology in the Appalachian region of southeastern Quebec, Canada: Yale Univ. Ph. D. dissert., 161 p.

1968a, Wisconsin stratigraphy and ice-movement directions in southeastern Quebec, Canada, in Abstracts for 1967: Geol. Soc. America Spec. Paper 115, p. 277-278.

$1968 \mathrm{~b}$, Deglaciation and differential postglacial rebound in the Appalachian region of southeastern Quebec: Jour. Geology, v. 76, p. 664-677.

1969. Surficial geology of the La Patrie-Sherbrooke area, Quebec, including Eaton River watershed: Geol. Survey Canada Paper 67-52, $21 \mathrm{p}$.

McDonald, B. C., and Shilts, W. W., 1971, Quaternary stratigraphy and events in southeastern Quebec: Geol. Soc. America Bull., v. 82, p. 683-698.

MacLachlan, D. C., 1939, Warren shore line in Ontario and in the thumb of Michigan and its deformation: Univ. Michigan Ph. D. dissert., $89 \mathrm{p}$.

1951, Post-glacial deformation in Ontario and Michigan, in Pleistocene features of the Huron-Saginaw ice lobes in Michigan: Geol. Soc. America Guidebook, Detroit Mtg., 1951, p. 31-34.

MacLean, W. F., 1961, Postglacial uplift in the Great Lakes region: Univ. Michigan, $\mathrm{Ph}$. D. dissert., $254 \mathrm{p}$.

Macpherson, J. B., 1967, Raised shorelines and drainage evolution in the Montreal lowland: Cahiers Géographie Québec, v. 23, p. 343-360.

Maher, L. J., Jr., 1970, Two creeks forest, Valders glaciation, and pollen grains, in R. F. Black, and others, Pleistocene geology of southern Wisconsin: Wisconsin Geol. and Nat. History Survey Inf. Circ. 15, pt. D, p. D1-D8.

Malott, C. A., 1922, The physiography of Indiana, in W. N. Logan, and others, Handbook of Indiana geology: Indiana Dept. Conserv. Pub. 21, p. 59-256.

Mangerud, Jan, 1972, Radiocarbon dating of marine shells, including a discussion of apparent age of Recent shells from Norway: Boreas, v. 1, p. 143-172.

Mangerud, Jan, Anderson, S. T., Berglund, B. E., and Donner, J. J., 1974, Quaternary stratigraphy of Norden, a proposal for terminology and classification: Boreas, v. 3, p. 109-128.

Marsters, Beverly, Spiker, Elliott, and Rubin, Meyer, 1969, U.S. Geological Survey radiocarbon dates X: Radiocarbon, v. 11 , no. 1, p. 210-227.

Martin, H. M., 1955, Map of the surface formations of the Southern Peninsula of Michigan: Michigan Dept. Conserv., Geol. Survey Div., Pub. 49, 9 p.

Mason, R. J., 1960, Early man and the age of the Champlain Sea: Jour. Geology, v. 68, p. 366-376.

Mather, K. F., 1917, The Champlain Sea in the Lake Ontario basin: Jour. Geology, v. 25, p. 542-554.

Melhorn, W. N., 1954, Valders glaciation of the Southern Peninsula of Michigan: Univ. Michigan Ph. D. dissert., $178 \mathrm{p}$.

1956, Valders drift in the Southern Peninsula of Michigan, in J. H. Zumberge, ed., The northwestern part of the Southern Peninsula of Michigan: Friends of the Pleistocene Guidebook. Midwest Sec., 7th Ann. Mtg.: p. 13-19.
Merrill, F. J. H., 1891, On the postglacial history of the Hudson River valley: Am. Jour. Sci., v. 41, p. 460-466.

Merritt, R. S., and Muller, E. H., 1959, Depth of leaching in relation to carbonate content of till in central New York State: Am. Jour. Sci., v. 257, p. 465-480.

Merwin, H. E., 1908, Some late Wisconsin and post-Wisconsin shore lines of northwestern Vermont, in Report of State Geologist on the mineral industries and geology of certain areas of Vermont, 1907-1908: Vermont State Geologist Rept. 6, p. 113-138.

Mickelson, D. M., 1973, Glacial stratigraphy of the Two Rivers lowland, Wisconsin, [Supplement to] E. B. Evenson, D. F. Eschman, and W. R. Farrand, [eds.], The "Valderan" problem, Lake Michigan basin: Friends of the Pleistocene Guidebook, Midwest Sec., 22d Ann. Field Conf., Michigan and Wisconsin, $1973,6 \mathrm{p}$.

Mickelson, D. M., and Evenson, E. B., 1975, Pre-Twocreekan age of the type Valders Till, Wisconsin: Geology, v. 3, p. 587-590.

Miller, N. G., 1969, Late- and postglacial vegetation change in southwestern New York State: Michigan State Univ. Ph. D. dissert., 325 p.

1973, Late-glacial and postglacial vegetation change in southwestern New York State: New York State Mus. and Sci. Service Bull. 420, $102 \mathrm{p}$.

Miller, N. G., and Benninghoff, W. S., 1969, Plant fossils from a Cary-Port Huron interstade deposit and their paleoecological interpretation: Geol. Soc. America Spec. Paper 123, p. 225-248.

Miller, W. J., 1909, Ice movement and erosion along the southwestern Adirondacks: Am. Jour. Sci., v. 27, p. 289-298.

1910, Pleistocene geology of the southwestern slope of the Adirondacks [abs.]: Geol. Soc. America Bull., v. 20, p. 635-637.

Mills, H. C., and Wells, P. D., 1974, Ice-shove deformation and glacial stratigraphy of Port Washington, Long Island, New York: Geol. Soc. America Bull., v. 85, p. 357-364.

Minard, J. P., 1961, End moraines on Kittatinny Mountain, Sussex County, New Jersey, in Short papers in the geologic and hydrologic sciences: U.S. Geol. Survey Prof. Paper 424-C, p. C61-C64.

Minard, J. P., and Rhodehamel, E. C., 1969, Quaternary geology of part of northern New Jersey and the Trenton area, field trip 3, in Seymour Subitzsky, ed., Geology of selected areas in New Jersey and eastern Pennsylvania and guidebook of excursions: New Brunswick, N.J., Rutgers Univ. Press, p. 279-313.

Miner, N. A., 1933, The origin and history of Green and Round Lakes in Green Lake State Park at Fayetteville, New York: Syracuse Univ. M.S. thesis, 46 p.

Mirynech, Edward, 1962, Pleistocene geology of the TrentonCampbellford map-area, Ontario: Univ. Toronto, Ontario, Ph. D. dissert., $176 \mathrm{p}$.

1963, Surficial geology, Sydenham, Bath, and Wellington map-areas: Geol. Survey Canada Paper 63-1, p. 46.

1967, Pleistocene and surficial geology of the KingstonCobourg-Tweed area, Ontario, in S. E. Jenness, ed., Geology of parts of eastern Ontario and western Quebec: Geol. Assoc. Canada Guidebook, Kingston, Ontario, 1967, p. 183-198.

Moore, D. W., 1974, The deposits and inferred history of Late Wisconsinan glacial Lake Watseka in east-central Illinois: Geol. Soc: America Abs. with Programs, v. 6, no. 6, p. 531-532.

Mörner, Nils-Axel, 1970a, Late Wisconsin ice marginal changes in Erie lobe area and comparison with late Weichselian sequence of southern Scandinavia: Geol. Soc. America Abs. with Programs, v. 2, no. 7, p. 751-752.

$1970 \mathrm{~b}$, Comparison between late Weichselian and late Wisconsin ice marginal changes: Eiszeitalter u. Gegenwart, v. 21, p. 173-176. 
Mörner, Nils-Axel, and Dreimanis, Aleksis, 1970, The Erie interstadial-type section, lake level, ice recession and correlations: Geol. Soc. America Abs. with Programs, v. 2, no. 7, p. 631.

1973, The Erie interstade, in R. F. Black, R. P. Goldthwait, and H. B. Willman, eds., The Wisconsinan Stage: Geol. Soc. America Mem. 136, p. 107-134.

Morrison, R. B., 1968, Means of time-stratigraphic division and long-distance correlation of Quaternary successions, in $\mathbf{R}$. B. Morrison, and H. E. Wright, Jr., eds., Means of correlation of Quaternary successions: Salt Lake City, Utah Univ. Press, p. 1-113.

Moss, J. H., and Ritter, D. F., 1962, New evidence regarding the Binghamton substage in the region between the Finger Lakes and Catskills, New York: Am. Jour. Sci., v. 260, p. 81-106.

Mott, R. J., 1968, A radiocarbon-dated marine algal bed of the Champlain Sea episode near Ottawa, Ontario: Canadian Jour. Earth Sci., v. 5, p. 319-324.

Mudge, E. H., 1899, The mouth of Grand River: Am. Jour. Sci., v. 8 , p. 31-34.

Muller, E. H., 1956, Texture as a basis of correlation of till sheets in Chautauqua County, western New York [abs.]:Am. Assoc.Adv. Sci., Ann. Mtg., New York, N. Y., 1956, sec. E, Program and Abs., p. 13.

1957, Physiography and glacial geology of Allegany County and vicinity, in Guidebook: New York State Geol. Assoc. 29th Ann. Mtg., Wellsville, N. Y., 1957, p. 4-10.

1960, Glacial geology of Cattaraugus County, New York: Friends of the Pleistocene Guidebook, Eastern Sec., 23d Reunion Dunkirk, 1960, 34 p.

1963, Pleistocene geology, pt. 2 of Geology of Chatauqua County, New York: New York State Mus. and Sci. Service Bull. $392,60 \mathrm{p}$.

1964a, Quaternary geology in New York State: Empire State Geogram, v. 2, no. 3, p. 12-16.

1964b, Surficial geology of the Syracuse field area, in J. J. Prucha, ed., Guidebook: New York State Geol. Assoc., 36th Ann. Mtg., Syracuse, N. Y., 1964, p. 25-35.

$1964 c$, Geomorphology of the north margin of the Appalachian uplands near Syracuse, in J. J. Prucha, ed., Guidebook: New York State Geol. Assoc., 36th Ann. Mtg., Syracuse, N. Y., 1964, p. 51-56.

1965a, Quaternary geology of New York, in H. E. Wright, Jr., and D. G. Frey, eds., The Quaternary of the United States: Princeton, N. J., Princeton Univ. Press, p. 99-112.

1965b, Late glacial history of the Black River and Oneida sublobes, in Guidebook for field conference A, New England-New York State, pt. 2: Internat. Assoc. Quaternary Research Cong., 7th, U.S.A., 1965, p. 54-59.

1965c, The Finger Lakes region, in Guidebook for field conference A, New England-New York State, pt. 2: Internat. Assoc. Quaternary Research Cong., 7th, U.S.A., 1965, p. 60-63, 65-69.

$1965 \mathrm{~d}$, Genesee valley and the Binghamton problem, in Guidebook for field conference A, New England-New York State, pt. 2: Internat. Assoc. Quaternary Research Cong., 7th, U.S.A., 1965, p. 71-79.

1966, Glacial geology and geomorphology between Cortland and Syracuse, in Field trip guidebook of the Cortland area: Natl. Assoc. Geology Teachers, Eastern Sec., Cortland, N. Y., 1966, p. 1-15.

1975, Central New York glacial meltwater channels in correlation of late Wisconsinan glacier marginal alignments: Geol. Soc. America Abs. with Programs, v. 7, no. 1, p. 98.
Muller, E. H., and Fahnestock, R. K., 1974, Glacial geology and buried topography in the vicinity of Fredonia, Gowanda, and Zoar Valley, New York, trip F, in D. N. Peterson, ed., Guidebook, geology of western New York State: New York State Geol. Assoc., 46th Ann. Mtg., Fredonia, N. Y., 1974, p. F1-F16.

Neel, Robert, 1951, Stratigraphy and glacial geology of the Portage quadrangle: Univ. Rochester M.S. thesis, pages unknown.

Newman, W. S., 1965, Late Pleistocene paleoenvironments of western Long Island Sound: New York Univ. Ph. D. dissert., $123 \mathrm{p}$.

1973, A very late Wisconsin glacial advance to western Long Island: Geol. Soc. America Abs. with Programs, v. 5, no. 2, p. 202.

Newman, W. S., Habib, Daniel, Krinsley, D. H., and Burckle, L. H., 1968, Late-Wisconsin lacustrine and marine episodes in Long Island Sound, New York, in Abstracts for 1967: Geol. Soc. America Spec. Paper 115, p. 281.

Newman, W. S., and Pike, T. J., 1975, Late Quaternary geology of northern Queens County, Long Island, New York: Geol. Soc. America Abs. with Programs, v. 7, no. 1, p. 99.

Newman, W. S., Thurber, D. H., Zeiss, H. S., Rokach, Allan, and Musich, Lillian, 1969, Late Quaternary geology of the Hudson River estuary-A preliminary report: New York Acad. Sci. Trans., v. 31, p. 548-570.

Nichols, G. C., 1972, Analysis of some raised strandlines in the southern Bruce Peninsula, Ontario, with particular reference to water planes of Lake Simcoe and Georgian Bay: Univ. Waterloo, Ontario, M.S. thesis, pages unknown.

Oakes, E. L., 1960, The Woodfordian moraines of Rock County, Wisconsin: Univ. Wisconsin, M.S. thesis, 61 p.

Occhietti, Serge, 1972, Moraine de poussée Valders (Dryas superieur) à Saint-Narcisse, Québec [abs.]: Internat. Geog. Cong., 22d, Montreal, 1972, La Géographie Internat., v. 1, p. 117-119.

1973a, Stratigraphie fini-glaciaire au nord du complexe morainique de Saint-Narcisse, région de Shawinigan [abs.]: Le Quaternaire du Québec, 2d Colloque, Montréal, Résumés des Commun., p. 21.

1973b, Eléments caractéristiques du complexe morainique de Saint-Narcisse en Mauricie et dans la région de Charlevoix [abs.]: Le Quaternaire du Québec, 2d Colloque, Montréal, Résumés des Commun., p. 21-22.

1974, Dépôts et faits Quaternaires du Bas Saint-Maurice, Quebec: Geol. Survey Canada Paper 74-1, pt. B, p. 217.

1976, Dépôts et faits Quaternaires du Bas-St-Maurice, Quebec: Geol. Survey Canada Paper 76-1, pt. C, p. 217-220.

Ogden, J. G., III, and Hart, W. C., 1976, Dalhousie University natural radiocarbon measurements I: Radiocarbon, v. 18, no. 1 , p. 43-49.

1977, Dalhousie University natural radiocarbon measurements II: Radiocarbon, v. 19, no. 3, p. 392-399.

Ogden, J. G., III, and Hay, R. J., 1965, Ohio Wesleyan University natural radiocarbon measurements II: Radiocarbon, v. 7, p. 166-173.

1967, Ohio Wesleyan University natural radiocarbon measurements III: Radiocarbon, v. 9, p. 316-332.

1969, Ohio Wesleyan University natural radiocarbon measurements IV: Radiocarbon, v. 11, no. 1, p. 137-149.

1973, Ohio Wesleyan University natural radiocarbon measurements V: Radiocarbon, v. 15, no. 2, p. 350-366.

O'Kileene, Sean, 1974, Deglaciation in the Ausable Valley, New York State: Carlton Univ. M.A. thesis, pages unknown. 
Olson, E. A., and Broecker, W. S., 1961, Lamont natural radiocarbon measurements VII: Radiocarbon, v. 3, p. 141-175.

Oltz, D. F., Jr., and Kapp, R. O., 1963, Plant remains associated with mastodon and mammoth remains in central Michigan: Am. Midland Naturalist, v. 70, p. 339-346.

Osborne, F. F., 1950, Marine crevasse fillings in the Lotbinière region, Quebec: Am. Jour. Sci., v. 248, p. 874-890.

1951, Parc des Laurentides ice cap and the Quebec Sea: Canadian Naturalist, v. 68, p. 221-251.

Pardi, R., 1977, Queens College radiocarbon measurements II: Radiocarbon, v. 19, no. 2, p. 237-244.

Parry, J. T., 1963, The Laurentians-A study in geomorphological development: McGill Univ. Ph. D. dissert., 222 p.

Parry, J. T., and MacPherson, J. C., 1964, The St. Faustin-St. Narcisse moraine and the Champlain Sea: Rev. Géographie Montréal, v. 18, p. 235-248.

Peet, C. E., 1904, Glacial and postglacial history of the Hudson and Champlain valleys: Jour. Geology, v. 12, p. 415-469, 617-660.

Perkins, G. H., 1912, Geological history of Lake Champlain, in Report of the State Geologist of Vermont for 1911-1912: Vermont Geol. Survey, p. 38-56.

Prest, V. K., 1969, Retreat of Wisconsin and Recent ice in North America: Geol. Survey Canada Map 1257A.

1970, Quaternary geology of Canada, Chap. 12, in R. J. W. Douglas, ed., Geology and economic minerals of Canada, [5th ed.]: Geol. Survey Canada Econ. Geology Rept. 1, p. 676-764.

Prest, V. K., and Keyser, J. H., 1962, Surficial geology and soils, Montreal area, Quebec: Montreal Dept. Public Works, 36 p.

Preston, R. S., Person, Elaine, and Deevey, E. S., 1955, Yale natural radiocarbon measurements II: Science, v. 122, p. 954-960.

Pryor, Michael, 1975, The glacial history of the Langford, New York, $7 \frac{1}{2}$ ' quadrangle and the southern half of the Hamburg, New York, 71/2' quadrangle: State Univ. New York at Buffalo, M.S. thesis, pages unknown.

Putnam, D. F., and Chapman, L. J., 1936, The physiography of south-central Ontario: Sci. Agriculture, v. 16, p. 457-477.

Quimby, G. I., 1958, Fluted points and geochronology of the Lake Michigan basin: Am. Antiquity, v. 23, p. 247-254.

Reeds, C. A., 1926, The varved clays at Little Ferry, New Jersey: Am. Mus. Novitates, no. 209, p. 1-16.

1927, Glacial lakes and clays near New York City: Nat. History, v. 27, p. 54-64.

Reinecke, L., 1917, Road materials surveys in 1915: Geol. Survey Canada Mem. 99 and Map 168A.

Rich, J. L., 1908, Marginal glacial drainage features in the Finger Lakes region: Jour. Geology, v. 16, p. 527-548.

1915, Notes on the physiography and glacial geology of the northern Catskill Mountains: Am. Jour. Sci., v. 39, p. 137-166. 1935, Glacial geology of the Catskills: New York State Mus. Bull. 299, 180 p.

1941, Glacial features of the Catskills: Friends of the Pleistocene Guidebook, Eastern Sec., 1941, pages unknown.

Richard, Pierre, and Poulin, Philippe, 1976, Un diagramme pollinique au Mont des Éboulements, région de Charlevoix, Québec: Canadian Jour. Earth Sci., v. 13, p. 145-156.

Richard, S. H., 1974, Surficial geology mapping-Ottawa-Hull area: Geol. Survey Canada Paper 74-1, pt. B, p. 218-219.

1975a, Surficial geology mapping-Morrisburg-Winchester area: Geol. Survey Canada Paper 75-1, pt. A, p. 417-418.

$1975 \mathrm{~b}$, Surficial geology mapping-Ottawa valley lowlands: Geol. Survey Canada Paper 75-1, pt. B, p. 113-117.
1976, Surficial geology mapping-Valleyfield-Rigaud area, Quebec: Geol. Survey Canada Paper 76-1, pt. A, p. 205-208.

1977, Surficial geology mapping-Valleyfield-Huntingdon area, Quebec: Geol. Survey Canada Paper 77-1, pt. A, p. 502-512.

Richmond, G. M., 1959, Application of stratigraphic classification and nomenclature to the Quaternary: Am. Assoc. Petroleum Geologists Bull, v. 43, no. 3, pt. I, p. 663-673.

Rieck, R. L., 1976, The glacial geomorphology of an interlobate area in southeast Michigan-Relationships between landforms, sediments, and bedrock: Michigan State Univ., Ph. D. dissert., $275 \mathrm{p}$.

Rondot, Jehan, 1974, L'épisode glaciaire de Saint-Narcisse dans Charlevoix, Québec: Rev. Géographie Montréal, v. 28, p. $375-388$

Rosengreen, T. E., 1974, Glacial geology of Highland County, Ohio: Ohio Geol. Survey Rept. Inv. 92, 36 p.

Rubin, Meyer, and Alexander, Corrinne, 1958, U.S. Geological Survey radiocarbon dates IV: Science, v. 127, p. 1476-1487. 1960, U.S. Geological Survey radiocarbon dates V: Radiocarbon, v. 2, p. 129-185.

Rubin, Meyer, and Berthold, S. M., 1961, U.S. Geological Survey radiocarbon dates VI: Radiocarbon, v. 3, p. 86-98.

Rubin, Meyer, and Suess, H. E., 1955, U.S. Geological Survey radiocarbon dates II: Science, v. 121, p. 481-488.

Ruhe, R. V., 1976, Stratigraphy of Mid-Continent loesses, in W. C. Mahaney, ed., Quaternary stratigraphy of North America: Stroudsburg, Pa., Dowden, Hutchinson, and Ross, p. 197-211.

Russell, I. C., 1905, A geological reconnaissance along the north shores of Lakes Huron and Michigan: Michigan Geol. Survey, Rept. for 1904 , p. 33-105.

Russell, I. C., and Leverett, Frank, 1915, Description of the Ann Arbor quadrangle, [revised ed.]: U.S. Geol. Survey Geol. Atlas, Folio 155, $18 \mathrm{p}$.

Saarnisto, Matti, 1974, The deglaciation history of the Lake Superior region and its climatic implications: Quaternary Research, v. 4, p. 316-339.

1975, Stratigraphical studies on the shoreline displacement of Lake Superior: Canadian Jour. Earth Sci., v. 12, p. 300-319.

Sabourin, R. J. E., compiler, 1957, Glacial map of Quebec: Univ. Laval, Quebec, Fac. Sci., Geology and Mineralogy, Contr. 128.

Salisbury, R. D., 1902, Pleistocene formations, in F. J. H. Merrill, N. H. Darton, Arthur Hollick, R. D. Salisbury, R. E. Dodge, Bailey Willis, and H. A. Pressy, Description of the New York City district: U.S. Geol. Survey Geol. Atlas, Folio 83, p. 10-17.

1908a, Quaternary System, in N. H. Darton, W. S. Bayley, R. D. Salisbury, and H. B. Kümmel, Description of the Passaic quadrangle [New Jersey-New York] U.S. Geol. Survey Geol. Atlas, Folio 157, p. 14-20.

1908b, Quaternary System, in A. C. Spencer, H. B. Kümmel, J. E. Wolff, R. D. Salisbury, and Charles Palache, Description of the Franklin Furnace quadrangle: U.S. Geol. Survey Geol. Atlas, Folio 161, p. 13-18.

Salisbury, R. D., and Alden, W. C., 1899, The geography of Chicago and its environs: Geog. Soc. Chicago Bull. 1, 64 p.

Salisbury, R. D., and Kümmel, H. B., 1895, Lake Passaic-an extinct glacial lake: Jour. Geology, v. 3, p. 533-560.

Salisbury, R. D., Kümmel, H. B., Peet, C. E., and Knapp, G. N., 1902, The glacial geology of New Jersey: New Jersey Geol. Survey, v. 5, 802 p. 
Salamon, Nena, 1976, Stratigraphy of glacial deposits along the south shore of Lake Ontario, New York: Syracuse Univ. M.S. thesis, $78 \mathrm{p}$.

Schafer, J. P., and Hartshorn, J. H., 1965, The Quaternary of New England, in H. E. Wright, Jr., and D. G. Frey, eds., The Quaternary of the United States: Princeton, N.J., Princeton Univ. Press, p. 113-128.

Schaffel, Simon, 1969, A late-glacial fresh-water lake in Long Island Sound in Abstracts for 1968: Geol. Soc. America Spec. Paper 121, p. 372-373.

1976, Reconstruction of late-glacial and postglacial events in Long Island Sound, New York: New York Univ. Ph. D. dissert., $115 \mathrm{p}$.

Schneider, A. F., 1968a, History of a morainal gap at Valparaiso, Indiana, in Abstracts for 1967: Geol. Soc. America Spec. Paper 115, p. 398-399.

1968b, The Tinley moraine in Indiana: Indiana Acad. Sci. Proc., v. 77, p. 271-278.

Schneider, A. F., and Johnson, G. H., 1967, Late Wisconsin glacial history of the area around Lake Maxinkuckee: Indiana Acad. Sci. Proc., v. 76, p. 328-334.

Schneider, A. F., and Reshkin, Mark, 1970, Age and correlation of the Glenwood stage of Glacial Lake Chicago: Geol. Soc. America Abs. with Programs, v. 2, no. 6, p. 404.

Schooler, E. E., 1974, Pleistocene beach ridges of northwestern Pennsylvania: Pennsylvania Geol. Survey Gen. Geology Rept. $64,38 \mathrm{p}$.

Schweger, C. E., 1969, Pollen analysis of Iola bog and paleoecology of the Two Creeks forest bed, Wisconsin: Ecology, v. 50, no. 5, p. 859-868.

Sears, P. B., 1966, Lake Lundy time: Science, v. 152, p. 386. 1967, The Castalia Prairie: Ohio Jour. Sci., v. 67, p. 78-88.

Semken, Holmes, Miller, B. B., and Stevens, J. B., 1964, Late Woodland musk ox in association with pollen and invertebrates from Michigan: Jour. Paleontology, v. 38, p. 823-835.

Sharpe, D. R., 1974, Quaternary geology of the Merrickville area, southern Ontario: Ontario Div. Mines Misc. Paper 59, p. 183-185.

1975, Quaternary geology of the Durham area, Grey County: Ontario Div. Mines Misc. Paper 63, p. 113-115.

1976, Quaternary geology of the Chesley-Tiverton $(41 \mathrm{~A} / 5$, A/6) area, Bruce County: Ontario Div. Mines Misc. Paper 67, p. 141-142.

Shepps, V. C., 1955, Glacial geology of a part of northwestern Pennsylvania: Illinois Univ. Ph. D. dissert., 109 p.

1959a, Introduction to the glacial geology of Crawford and Erie Counties, Pennsylvania, in Guidebook: Pennsylvania Geol. Survey 24th Ann. Field Conf. of Pennsylvania Geologists, Titusville, Pa., 1959, p. 1-11.

1959b, Glacial geology of northwestern Pennsylvania, trip 5, in Guidebook for field trips: Geol. Soc. America Pittsburg Mtg., 1959, p. 167-188.

Shepps, V. C., White, G. W., Droste, J. B., and Sitler, R. F., 1959, Glacial geology of northwestern Pennsylvania: Pennsylvania Geol. Survey Bull. G32, 59 p.

Sherzer, W. H., 1900, Geological report on Monroe County, Michigan: Michigan Geol. Survey, v. 7, pt. 1,240 p.

1913, Geological report on Wayne County, Michigan: Michigan Geol. Survey Pub. 12, Geol. Ser. 9,308 p.

1917, Description of the Detroit district: U.S. Geol. Survey Geol. Atlas, Folio 205, 22 p.

Shilts, W. W., 1965, A laboratory study of Late Pleistocene sediments in the Jay Peak, Irasburg, and Memphremagog quadrangles, Vermont: Miami Univ., Ohio, M.S. thesis, pages unknown. 1966a, The Pleistocene geology of the Bennington area, Vermont: Vermont Geol. Survey open-file report to the State Geologist, pages unknown.

$1966 \mathrm{~b}$, The Pleistocene geology of the Wilmington area, Vermont: Vermont Geol. Survey open-file report to the State Geologist, pages unknown.

1969, Pleistocene geology of the Lac Mégantic region, southeastern Quebec, Canada: Syracuse Univ. Ph. D. dissert., 154 p.

1970 , Pleistocene history and glacio-tectonic features in the Lac Mégantic region, Quebec, trip E-1, in G. M. Boone, ed., Guidebook for field trips in the Rangeley Lakes-Dead River Basin region, western Maine: New England Intercollegiate Geol. Conf., 62d Ann. Mtg., Rangeley, Me., 1970, p. 1-14.

1973, Glacial dispersal of rocks, minerals, and trace elements in Wisconsinan till, southeastern Quebec, Canada, in R. F. Black, R. P. Goldthwait, and H. B. Willman, eds., The Wisconsinan Stage: Geol. Soc. America Mem. 136, p. 189-219.

Shilts, W. W., and Behling, R. E., 1967, Deglaciation of the Vermont Valley and adjacent highlands [abs.]: Geol. Soc. America Ann. Meeting, 1967, New Orleans, Program, p. 203.

Shumaker, R. C., 1957, Till texture variation and Pleistocene deposits of the Union Springs and Scipio quadrangles, Cayuga County, New York: Cornell Univ. M.S. thesis, 44 p.

Shutler, Dick, Jr., and Damon, P. E., 1959, University of Arizona radiocarbon dates II: Radiocarbon, v. 1, p. 59-62.

Singer, S., 1973, Surficial geology along the north shore of Lake Ontario in the Bowmanville-Newcastle area, in Great Lakes Research Conference, 16th, Ann Arbor, Mich., 1973, Proceedings: p. 441-453.

Sirkin, L. A., 1967a, Correlation of late glacial pollen stratigraphy and environments in the northeastern U.S.A.: Rev. Palaeobotany and Palynology, v. 2, p. 205-218.

1967b, Late-Pleistocene pollen stratigraphy of western Long Island and eastern Staten Island, New York, in E. J. Cushing, and H. E. Wright, Jr., eds., Quaternary paleoecology: New Haven, Conn., Yale Univ. Press, p. 249-274.

1971, Surficial glacial deposits and postglacial pollen stratigraphy in central Long Island, New York: Pollen et Spores, v. 13, p. 93-100.

Sirkin, Leslie, and Mills, H. C., 1975, Wisconsinan glacial stratigraphy and structure of northwestern Long Island, in M. P. Wolff, ed., Guidebook to field excursions: New York State Geol. Assoc., 47th Ann. Mtg., 1975: p. 299-327.

Sirkin, L. A., and Minard, J. P., 1972, Late Pleistocene glaciation and pollen stratigraphy in northwestern New Jersey, in Geological Survey research 1972: U.S. Geol. Survey Prof. Paper 800-D, p. D51-D56.

Sissons, J. B., 1960, Subglacial, marginal, and other glacial drainage in the Syracuse-Oneida area, New York: Geol. Soc. America Bull., v. 71, p. 1575-1588.

Sitler, R. F., 1957, Glacial geology of a part of western Pennsylvania: Illinois Univ. Ph. D. dissert., pages unknown.

Sly, P. G., and Lewis, C. F. M., 1972, The Great Lakes of CanadaQuaternary geology and limnology, in Guidebook for field excursion A43: Internat. Geol. Cong., 24th, Montreal, 1972, 92 p.

Spencer, J. W., 1882, Terraces and beaches about Lake Ontario: Am. Jour. Sci., v. 24, p. 409-416.

1889, The Iroquois beach-a chapter in the geological history of Lake Ontario: Royal Soc. Canada Trans., v. 7, sec. 4, p. 121-134.

1890, The deformation of Iroquois beach and birth of Lake Ontario: Am. Jour. Sci., v. 40, p. 443-451.

1891a, Deformation of the Algonquin beach, and birth of Lake Huron: Am. Jour. Sci., v. 41, p. 12-21. 
$1891 \mathrm{~b}$, High level shores in the region of the Great Lakes, and their deformation: Am. Jour. Sci., v. 41, p. 201-211.

1891c, Post-Pliocene continental subsidence versus glacial dams: Geol. Soc. America Bull., v. 2, p. 465-476.

1892, The Iroquois shore north of the Adirondacks: Geol. Soc. America Bull., v. 3, p. 488-491.

1894a, A review of the history of the Great Lakes: Am. Geologist, v. 14, p. 289-301.

$1894 \mathrm{~b}$, Deformation of the Lundy beach and birth of Lake Erie: Am. Jour. Sci., v. 47, p. 207-212.

1898, On Mr. Frank Leverett's "Correlation of moraines with beaches on the border of Lake Erie": Am. Geologist, v. 21, p. 393-396.

1912, Covey Hill revisited: Geol. Soc. America Bull., v. 23, p. 471-476.

1913, Postglacial earth movements about Lake Ontario and the Saint Lawrence River: Geol. Soc. America Bull., v. 24, p. 217-228.

Spiker, Elliott, Kelley, Lea, Oman, Charles, and Rubin, Meyer, 1977, U.S. Geological Survey radiocarbon dates XII: Radiocarbon, v. 19 , no. 2, p. 332-353.

Spurr, S. H., and Zumberge, J. H., 1956, Late Pleistocene features of Cheboygan and Emmet Counties, Michigan: Am. Jour. Sci., v. 254, p. 96-109.

Sreenivasa, B. A., 1968, A late glacial and postglacial pollen diagram from the Waterloo moraine: Univ. Waterloo, Ontario, M.S. thesis, pages unknown.

1973, Paleoecological studies of Sunfish Lake and its environs: Univ. Waterloo, Ontario, Ph. D. dissert., 184 p.

Stanley, G. M., 1936, Lower Algonquin beaches of Penetanguishene Peninsula: Geol. Soc. America Bull., v. 47, p. 1933-1960.

1937, Lower Algonquin beaches of Cape Rich, Georgian Bay: Geol. Soc. America Bull., v. 48, p. 1665-1686.

1938a, Impounded Early Algonquin beaches at Sucker Creek, Grey County, Ontario: Michigan Acad. Sci., Arts and Letters Papers, v. 23, p. 477-495.

1938b, The submerged valley through Mackinac Straits: Jour. Geology, v. 46, p. 966-974.

Steiger, J. R., 1967, Mechanical and carbonate analysis of soil parent material derived from glacial tills and lacustrine deposits in western Ohio: Ohio State Univ. M.S. thesis, $127 \mathrm{p}$.

Steiger, J. R., and Holowaychuk, Nicholas, 1971, Particle-size and carbonate analysis of glacial till and lacustrine deposits in western Ohio, in R. P. Goldthwait, and others, eds., Till-A symposium: Geol. Soc. America, Columbus, Ohio, 1969, Ohio State Univ. Press, p. 275-289.

Stewart, D. P., 1958, The Pleistocene geology of the Watertown and Sackets Harbor quadrangles, New York: New York State Mus. Bull. 369, 79 p.

1961, The glacial geology of Vermont: Vermont Geol. Survey Bull. 19, $124 \mathrm{p}$.

Stewart, D. P., and MacClintock, Paul, 1964, The Pleistocene stratigraphy of northern Vermont: Am. Jour. Sci., v. 262, p. 1089-1097.

1969, The surficial geology and Pleistocene history of Vermont: Vermont Geol. Survey Bull. 31, 251 p.

1970 , Surficial geologic map of Vermont: Vermont Geol. Survey.

1971, Ablation till in northeastern Vermont, in R. P. Goldthwait and others, eds., Till-a symposium: Geol. Soc. America, Columbus, Ohio, 1969, Ohio State Univ. Press, p. 106-114.

Stoller, J. H., 1911, Glacial geology of the Schenectady quadrangle: New York State Mus. Bull. 154, 44 p.
1916, Glacial geology of the Saratoga quadrangle: New York State Mus. Bull. 183,50 p.

1920, Glacial geology of the Cohoes quadrangle: New York State Mus. Bull. 215, 216, 47 p.

1919, Topographic features of the Hudson valley and the question of postglacial marine waters in the Hudson-Champlain Valley: Geol. Soc. America Bull., v. 30, p. 415-422.

1922, Late Pleistocene history of the lower Mohawk and middle Hudson region: Geol. Soc. America Bull., v. 33, p. 515-526.

Stone, B. D., and Thompson, W. B., 1971, Late Wisconsin glacial readvance deposits on Isle La Motte, Vermont: Geol. Soc. America Abs. with Programs, v. 3, no. 1, p. 57.

Stoutamire, W. P., and Benninghoff, W. S., 1964, Biotic assemblage associated with a mastodon skull from Oakland County, Michigan: Michigan Acad. Sci., Arts and Letters Papers, v. 49, p. 47-60.

Straw, Allan, 1968a, A geomorphological appraisal of the deglaciation of an area between Hamilton and Guelph, southern Ontario: Canadian Geographer, v. 12, p. 135-143.

1968b, Late Pleistocene glacial erosion along the Niagara Escarpment of southern Ontario: Geol. Soc. America Bull., v. 79, p. 889-910.

Straw, W. T., 1976, Guidebook for a field trip on some aspects of the glacial geology in the Kalamazoo area: Kalamazoo, Univ. Western Michigan, Dept. Geology, 28 p.

Street, J. S., 1966, Glacial geology of the eastern and southern portions of the Tug Hill Plateau, New York: Syracuse Univ. Ph. D. dissert., $167 \mathrm{p}$.

Stuiver, Minze, 1969, Yale natural radiocarbon measurements IX: Radiocarbon, v. 11, no. 2, p. 545-658.

Stuiver, Minze, Deevey, E. S., and Gralenski, L. J., 1960, Yale natural radiocarbon measurements $\mathrm{V}$ : Radiocarbon, v. 2, p. 49-61.

Suess, H. E., 1954, U.S. Geological Survey radiocarbon dates I: Science, v. 120, p. 467-473.

Sutton, R. G., Lewis, T. L., and Woodrow, D. L., 1972, Post-Iroquois lake stages and shoreline sedimentation in eastern Ontario basin: Jour. Geology, v. 80, p. 346-356.

Symecko, R. E., 1967, Glacial geology of the Orchard Park, New York, quadrangle: State Univ. New York at Buffalo, M.A. thesis, $64 \mathrm{p}$.

Tarr, R. S., 1905a, Moraines of the Seneca and Cayuga Lake valleys: Geol. Soc. America Bull., v. 16, p. 215-228.

1905b, Drainage features of central New York: Geol. Soc. America Bull., v. 16, p. 229-242.

1909, Quaternary System, in H. S. Williams, R. S. Tarr, and E. M. Kindle, Description of the Watkins Glen-Catatonk district [New York]: U.S. Geol. Survey Geol. Atlas, Folio 169, p. 15-28.

Taylor, F. B., 1892, The highest old shore line on Mackinac Island: Am. Jour. Sci., v. 43, p. 210-218.

$1894 \mathrm{a}$, The limit of postglacial submergence in the highlands east of Georgian Bay: Am. Geologist, v. 14, p. 273-289.

$1894 \mathrm{~b}$, A reconnaissance of the abandoned shore lines of Green Bay: Am. Geologist, v. 13, p. 316-327.

1895a, The Munuscong Islands (Michigan): Am. Geologist, v. 15, p. 24-33.

1895b, The second Lake Algonquin: Am. Geologist, v. 15, p. 100-120, 162-179.

1895c, Niagara and the Great Lakes: Am. Jour. Sci., v. 49, p. 249-270.

1896a, Preliminary notes on studies of the Great Lakes made in 1895: Am. Geologist, v. 17, p. 253-257. 
1896b, The Algonquin and Nipissing beaches: Am. Geologist, v. 17 , p. $397-400$.

$1896 \mathrm{c}$, Notes on the Quaternary geology of the Mattawa and Ottawa valleys: Am. Geologist, v. 18, p. 108-120.

$1896 \mathrm{~d}$, Correlation of Warren beaches with moraines and outlets in southeastern Michigan [abs.]: Am. Geologist, v. 18, p. 233-234.

1897, Correlation of Erie-Huron beaches with outlets and moraines in southeastern Michigan: Geol. Soc. America Bull., v. 8, p. 31-58.

1899, The great ice dams of Lakes Maumee, Whittlesey, and Warren: Am. Geologist, v. 24, p. 6-38.

1902, Surface geology of Lapeer County, Michigan: Michigan Geol. Survey, Rept. for 1901, p. 109-117.

1905, Relation of Lake Whittlesey to the Arkona beaches: Michigan Acad. Sci., 7th Ann. Rept., p. 29-36.

1909, Field work on the Pleistocene deposits of south-western Ontario: Geol. Survey Canada, Summary Rept. for 1908, p. 103-111.

1910, The glacial recession in western New England [abs.]: Science, v. 32, p. 127-128.

1912, Recent studies of the moraines of Ontario and western New York [abs.]: Geol. Soc. America Bull., v. 23, p. 736-737.

1913a, The moraine systems of southwestern Ontario: Royal

Canadian Inst. Trans., v. 10, pt. 1, p. 57-79.

1913b, Moraines north of Toronto, in Guidebook no. 6, Excursions in vicinity of Toronto and to Muskoka and Madoc: Internat. Geol. Cong., 12th, Toronto, 1913: Toronto, Ontario Bur. Mines, p. 35-42.

1913c, The glacial and postglacial lakes of the Great Lakes region: Smithsonian Inst., Ann. Rept. for 1912, p. 291-327.

1924, Moraines of the St. Lawrence valley: Jour. Geology, v. 32, p. 641-647.

1925a, Reconnaissance of the recessional moraines of the Finger Lakes region [abs.]: Geol. Soc. America Bull., v. 36, p. 142.

$1925 \mathrm{~b}$, Moraines of recession between Indiana and New England [abs.]: Geol. Soc. America Bull., v. 36, p. 172-173.

1925c, Relation of recessional moraines to Niagara Falls:

Pan-Am. Geologist, v. 44, p. 153-154.

1931, Retreat of the front of the last ice sheet in New York and New England [abs.]: Geol. Soc. America Bull., v. 42, p. 334.

1932, Recessional moraines in the Buffalo-Genesee and Finger Lakes areas [abs.]: Geol. Soc. America Bull., v. 43, p. 189-190.

1939, Correlatives of the Port Huron morainic system of Michigan in Ontario and western New York: Am. Jour. Sci., v. 237, p. 375-388.

Taylor, L. D., 1977, Preliminary analysis of glacial stratigraphy in the vicinity of Port Huron and Two Rivers till sheets, Manistee, Michigan: Geol. Soc. America Abs. with Programs, v. 9 , no. 5 , p. 658 .

Terasmae, Jaan, 1959, Notes on the Champlain Sea episode in the St. Lawrence Lowlands, Canada: Science, v. 130, p. 334-336.

$1960 a$, Surficial geology of the Cornwall, Ontario, map-area: Geol. Survey Canada Paper 60-28, 4 p.

$1960 \mathrm{~b}$, A palynological study of post-glacial deposits in the St. Lawrence Lowlands: Geol. Survey Canada Bull. 56, pt. 1, p. 1-22.

1965, Surficial geology of the Cornwall and St. Lawrence Seaway project areas, Ontario: Geol. Survey Canada Bull. 121, $54 \mathrm{p}$.

Terasmae, Jaan, and Dreimanis, Aleksis, 1976, Quaternary stratigraphy of southern Ontario, in W.C. Mahaney, ed., Quaternary Stratigraphy of North America: Stroudsburg Pa., Dowden, Hutchinson, and Ross, p. 51-63.
Terasmae, Jaan, and Hughes, O. L., 1960, Glacial retreat in the North Bay area, Ontario: Science, v. 131, p. 1444-1446.

Terasmae, Jaan, Karrow, P. F., and Dreimanis, Aleksis, 1972, Quaternary stratigraphy and geomorphology of the eastern Great Lakes region of southern Ontario, in Guidebook for field excursion A42: Internat. Geol. Cong., 24th, Montreal, 1972, $75 \mathrm{p}$.

Terasmae, Jaan, and LaSalle, P., 1968, Notes on late-glacial palynological and geochronology at St. Hilaire, Quebec: Canadian Jour. Earth Sci., v. 5, p. 249-257.

Terasmae, Jaan, and Mirynech, E., 1964, Postglacial chronology and the origin of deep lake basins in Prince Edward County, Ontario, in Great Lakes Research Conference, 7th, Toronto, Canada, 1964, Proceedings: Michigan Univ. Inst. Sci. and Technology, Great Lakes Research Div. Pub. 11, p. 161\#169.

Terwilliger, F. W., 1954, The glacial geology and groundwater resources of Van Buren County, Michigan, pt. 1 of occasional papers for 1954 on the geology of Michigan: Michigan Geol. Survey Pub. 48., p. 1 \#96.

Tharin, J. C., 1958, Textural studies of the Wisconsin tills of northwestern Pennsylvania: Illinois Univ., M.S. thesis, pages unknown.

Thornbury, W. D., 1958, The geomorphic history of the upper Wabash valley: Am. Jour. Sci., v. 256, p. 449-469.

Thornbury, W. D., and Deane, H. L., 1955, The geology of Miami County, Indiana: Indiana Geol. Survey Bull. 8, 49 p.

Thornes, J. B., 1964, The late-glacial geomorphic evolution of the Coaticook and Moe River valleys, southern Quebec: McGill Univ., M.S. thesis, pages unknown.

1965 , Some observations on the late-glacial stages in the Coaticook Valley, southern Quebec: Cahiers Geographie Québec, 9th year, no. 18, p. 223-238.

Thurber, D. L., Broecker, W. S., and Kaufman, A., 1967, The comparison of radiocarbon ages of carbonates with uranium series ages, in Radiocarbon and tritium dating, International Conference, 6th, Washington State University, Pullman, Wash., 1965, Proceedings: U.S. Atomic Energy Comm., CONF-650652, p. 367-382.

Thwaites, F. T., 1943, Pleistocene of part of northeastern Wisconsin: Geol. Soc. America Bull., v. 54, p. 87-144.

1949, Geomorphology of the basin of Lake Michigan: Michigan Acad. Sci. Papers, v. 33, p. 243-251.

Thwaites, F. T., and Bertrand, K., 1957, Pleistocene geology of the Door Peninsula, Wisconsin: Geol. Soc. America Bull., v. 68, p. 831-880.

Totten, S. M., 1960, Quartz/feldspar ratios of tills in northeastern Ohio: Illinois Univ. M.S. thesis, pages unknown.

1962, Glacial geology of Richland County, Ohio: Illinois Univ. Ph. D. dissert., 136 p.

1969, Overridden recessional moraines of north-central Ohio: Geol. Soc. America Bull., v. 80, p. 1931-1946.

1973, Glacial geology of Richland County, Ohio: Ohio Geol. Survey Rept. Inv. 88, 55 p.

1976, The "up-in-the-air" late Pleistocene beaver pond near Lodi, Medina County, northern Ohio: Geol. Soc. America Abs. with Programs, v. 8, no. 4, p. 514.

Tovell, W. M., and Deane, R. E., 1966, Grizzly bear skull-Site of a find near Lake Simcoe: Science, v. 154, p. 158.

Trainer, F. W., and Salvas, E. H., 1962, Ground-water resources of the Massena-Waddington area, St. Lawrence County, New York, with emphasis on the effect of Lake St. Lawrence on ground water: New York Water Resources Comm. Bull. GW-47, $227 \mathrm{p}$.

Tucek, C. S., 1977, Radiocarbon, Ltd. natural radiocarbon measurements II: Radiocarbon, v. 19, no. 2, p. 245-262. 
Upham, Warren, 1891, Glacial lakes in Canada: Geol. Soc. America Bull., v. 2, p. 243-274.

1892, Relationship of the Glacial Lakes Warren, Algonquin, Iroquois, and Hudson-Champlain: Geol. Soc. America Bull., v. 3, p. 484-487.

1895a, Late glacial or Champlain subsidence and reëlevation of the St. Lawrence River basin: Am. Jour. Sci., v. 49, p. 1-18. $1895 \mathrm{~b}$, Departure of the ice-sheet from the Laurentian lakes [abs.]: Geol. Soc. America Bull., v. 6, p. 21-27.

1896a, Beaches of Lakes Warren and Algonquin: Am. Geologist, v. 17, p. 400-402.

1896b, Beach ridges in Cleveland: Geol. Soc. America Bull., v. 7 , p. $340-348$.

$1896 \mathrm{c}$, Origin and age of the Laurentian lakes and of Niagara Falls: Am. Geologist, v. 18, p. 169-177.

1903, The Glacial Lakes Hudson-Champlain and St. Lawrence: Am. Geologist, v. 32, p. 223-230.

1905, Glacial lakes and marine submergence in the HudsonChamplain valley: Am. Geologist, v. 36, p. 285-289.

Vagners, U. J., 1966, Lithologic relationship of till to carbonate bedrock in southern Ontario: Univ. Western Ontario, Ontario, M.S. thesis, $154 \mathrm{p}$.

1970a, Mineral distribution in tills in central and southern Ontario: Univ. Western Ontario, Ontario, Ph. D. dissert., 277 p.

1970b, Pleistocene geology of the Windsor-Essex region, southern Ontario: Ontario Dept. Mines Misc. Paper 43, p. 93-94.

1972, Quaternary geology, Lucan area, southern Ontario: Ontario Dept. Mines Misc. Paper 53, p. 153-156.

Van Wyckhouse, R. J., 1966, A study of test borings from the Pleistocene of the southeastern Michigan glacial lake plain: Wayne State Univ., M.S. thesis, 84 p.

Vick, R. M., 1956, The Ingersoll and Westminster end moraines of the London area: Univ. Western Ontario, Senior thesis, pages unknown.

von Engeln, O. D., 1921, The Tully glacial series: New York State Mus. Bull. 227, 228, p. 39-62.

1961, The Finger Lakes region-Its origin and nature: Ithaca, N.Y., Cornell Univ. Press, 156 p.

de Vries, Hessel, and Barendsen, G. W., 1958, Groningen radiocarbon dates III: Science, v. 128, p. 1550-1556.

Wagner, W. P., 1969, The late Pleistocene of the Champlain Valley, Vermont, trip D, in S. G. Barnett, ed., Guidebook to field excursions: New York State Geol. Assoc., 41st Ann. Mtg., Burlington, Vt., 1969, p. 65-80.

1970, Laurentide ice margin and associated water bodies in the Champlain valley of northwestern Vermont: Am. Quaternary Assoc., Conf., 1st, Yellowstone Park, Wyo., and Bozeman, Mont., Abs., p. 141.

1972, Ice margins and water levels in northwestern Vermont in B. L. Doolan, and R. S. Stanley, eds., Guidebook for field trips in Vermont: New England Intercollegiate Geol. Conf., 64th Ann. Mtg., Burlington, Vt., 1972, p. 317-342.

Wagner, W. P., Morse, J. D., and Howe, C. C., 1972, Till studies, Shelburne, Vermont, in B. L. Doolan, and R. S. Stanley, eds. Guidebook for field trips in Vermont: New England Intercollegiate Geol. Conf., 64th Ann. Mtg., Burlington, Vt., 1972, p. 377-388.

Wall, R. E., 1968, A sub-bottom reflection survey in the central basin of Lake Erie: Geol. Soc. America Bull., v. 79, p. 91-106.

Walton, Alan, Trautman, M. A., and Friend, J. P., 1961, Isotopes, Inc. radiocarbon measurements I: Radiocarbon, v. 3, p. 47-59.

Watson, T. L., 1898, Some higher levels in the postglacial development of the Finger Lakes: New York State Mus. 51st Ann. Rept., p. 55-117.
Wayne, W. J., 1952, Pleistocene evolution of the Ohio and Wabash valleys: Jour. Geology, v. 60, p. 575-585.

1954, Guidebook to the glacial geology of northern Steuben County, Indiana: Indiana Acad. Sci. Guidebook, pages unknown.

1958, Glacial geology of Indiana: Indiana Geol. Survey Atlas Mineral Resources Map 10.

1963, Pleistocene formations in Indiana: Indiana Geol. Survey Bull. 25, 85 p.

1965a, The Crawfordsville and Knightstown moraines in Indiana: Indiana Geol. Survey Rept. Prog., 28, 15 p.

1965b, Western and central Indiana, in Guidebook for field conference G, Great Lakes-Ohio River Valley: Internat. Assoc. Quaternary Research Cong., 7th, U.S.A., 1965, p. 27-42.

1966, Ice and land-A review of the Tertiary and Pleistocene history of Indiana, Chap. 2, in A. A. Lindsey, ed., Natural features of Indiana: Indiana Acad. Sci., p. 21-39.

1967, Periglacial features and climatic gradient in Illinois, Indiana, and western Ohio, east-central United States, in E. J. Cushing, and H. E. Wright, Jr., eds., Quaternary paleoecology: New Haven, Conn., Yale Univ. Press, p. 393-414.

1968, The Erie lobe margin in east-central Indiana during the Wisconsin glaciation: Indiana Acad. Sci. Proc., v. 77, p. 279-291.

1973, Multiple tills at Wabash, Indiana [abs.]: Indiana Acad. Sci. Proc., v. 83, p. 242-243.

Wayne, W. J., and Thornbury, W. D., 1951, Glacial geology of Wabash County, Indiana: Indiana Geol. Survey Bull. 5, 39 p. 1955, Wisconsin stratigraphy of northern and eastern Indiana, in Guidebook: Pleistocene Field Conf., 5th Biennial, Illinois and Indiana, 1975, p. 1-34.

Wayne, W. J., and Zumberge, J. H., 1965, Pleistocene geology of Indiana and Michigan, in H. E. Wright, Jr., and Frey, D. G., eds., The Quaternary of the United States: Princeton, N.J., Princeton Univ. Press, p. 63-84.

Weiss, Dennis, 1971, Late Pleistocene stratigraphy and paleoecology of the lower Hudson River estuary: New York Univ. Ph. D. dissert., $160 \mathrm{p}$.

1974, Late Pleistocene stratigraphy and paleoecology of the lower Hudson River estuary: Geol. Soc. america Bull., v. 85, p. 1561-1570.

Westgate, J. A., and Dreimanis, A., 1967, The Pleistocene sequence of Zorra, southwestern Ontario: Canadian Jour. Earth Sci., v. 4, p. 1127-1143.

Whipple, J. M., 1969, Glacial geology of the area from Little Falls to Richfield Springs, New York: Rensselaer Polytechnic Inst. Ph. D. dissert., $158 \mathrm{p}$.

White, G. W., 1931, Glaciation of northwestern Holnes County, Ohio: Ohio Jour. Sci., v. 31, p. 429-453.

1935, The Powell and Broadway end moraines: Am. Jour. Sci., v. 30, p. 33-44.

1939, End moraines of north-central Ohio: Jour. Geology, v. 47,p. 277-289.

1949, Geology of Holmes County: Ohio Geol. Survey Bull. $47,373 \mathrm{p}$.

1953a, Geology and water-bearing characteristics of the unconsolidated deposits of Cuyahoga County, in J. D. Winslow, G. W. white, and E. E. Webber, The water resources of Cuyahoga County, Ohio: Ohio Div. Water, Bull. 26, p. 36-42.

$1953 \mathrm{~b}$, Geology and water-bearing properties of the unconsolidated deposits, in R. C. Smith, and G. W. White, The ground-water resources of Summit County, Ohio: Ohio Div. Water Bull. 27, p. 18-27.

1960, Classification of Wisconsin glacial deposits in northeastern Ohio: U.S. Geol. Survey Bull. 1121-A, 12 p. 
1961, Classification of glacial deposits in the Killbuck lobe, northeast-central Ohio, in Short papers in the geologic and hydrologic sciences: U.S. Geol. Survey Prof. Paper 424-C, p. C71-C73.

1962, Multiple tills of end moraines, in Short papers in geology and hydrology: U.S. Geol. Survey Prof. Paper 450-C, p. C96-C98.

1963, Glacial geology of Stark County, Ohio, in R. M. DeLong, and G. W. White, Geology of Stark County: Ohio Geol. Survey Bull. 61, p. 118-156.

1965, Northeast Ohio, in Guidebook for field conference G, Great Lakes-Ohio River valley: Internat. Assoc. Quaternary Research, 7th, U.S.A., 1965, p. 82-90.

1967, Glacial geology of Wayne County, Ohio: Ohio Geol. Survey Rept. Inv. 62, 39 p.

1969, Pleistocene deposits of north-western Allegheny Plateau, U.S.A.: Geol. Soc. London, Quart. Jour., v. 124, [for 1968], p. 131-149, discussions and replies, p. 149-151.

1971, Glacial geology of Trumbull County, Ohio: Ohio Geol. Survey Rept. Inv. 80.

1973, Glacial geology of Holnes County, Ohio: Ohio Geol. Survey Rept. Inv. 91.

1977, Glacial geology of Ashland County, Ohio: Ohio Geol. Survey Rept. Inv, 101.

White, G. W., Droste, J. B., Sitler, R. E., and Shepps, V. C., 1957, Glacial deposits of northwestern Pennsylvania [abs.]: Geol. Soc. America Bull., v. 68, p. 1902-1903.

White, G. W., Totten, S. M., and Gross, D. L., 1969, Pleistocene stratigraphy of northwestern Pennsylvania: Pennsylvania Geol. Survey Bull. G55, 88 p.

White, O. L., 1975, Quaternary geology of the Bolton area, southern Ontario: Ontario Div. Mines Geol. Rept. 117, 119 p.

Widmer, Kemble, and Parrillo, D. G., 1959, Pre-Pleistocene topography of the Hackensack Meadows, New Jersey [abs.]: Geol. Soc. America Bull., v. 70, no. 12, pt. 2, p. 1698.

Wilding, L. P., Drees, L. R., Smeck, N. E., and Hall, G. F., 1971, Mineral and elemental composition of Wisconsin-age till deposits in west-central Ohio, in R. P. Goldthwait, and others, eds., Till-A symposium: Geol. Soc. America, Columbus, Ohio, 1969, Ohio State Univ. Press, p. 290-317.

Wilkinson, R. S., 1959, Differential uplift of the Iroquois shoreline: Univ. Toronto, Ontario, B.S. thesis, pages unknown.

Williams, A. S., 1974, Late-glacial-postglacial vegetational history of the Pretty Lake region, northeastern Indiana: U.S. Geol Survey Prof. Paper 686-B, 23 p.
Willınan, H. B., 1971, Summary of the geology of the Chicago area: Illinois Geol. Survey Circ. 460, 77 p.

Willman, H. B., and Frye, J. C., 1970, Pleistocene stratigraphy of Illinois: Illinois Geol. Survey Bull. 94, 204 p.

Winslow, J. D., and White, G. W., 1966, Geology and groundwater resources of Portage County, Ohio: U.S. Geol. Survey Prof. Paper 511, $80 \mathrm{p}$.

Woodworth, J. B., 1901, Pleistocene geology of portions of Nassau County and the Borough of Queens: New York State Mus. Bull. 48, p. 617-670.

1905a, Pleistocene geology of the Mooers quadrangle: New York State Mus. Bull. 83, 62 p.

$1905 \mathrm{~b}$, Ancient water levels of the Champlain and Hudson valleys: New York State Mus. Bull. 84, p. 63-265.

Wright, Frank, 1972, The Pleistocene and Recent geology of the Oneida-Rome district, New York: Syracuse Univ. Ph. D. dissert., $181 \mathrm{p}$.

Wright, G. F., 1895, Glacial phenomena between Lake Champlain, Lake George, and Hudson River: Science, v. 2, p. 673-678.

1918, Explanation of the abandoned beaches about the south end of Lake Michigan: Geol. soc. America Bull., v. 29, p. 235-244.

Wright, H. E., Jr., 1971, Retreat of the Laurentide ice sheet from 14,000 to 9,000 years ago: Quaternary Res., v. 1, p. 316-330. 1976 , Ice retreat and revegetation in the western Great Lakes area, in W. C. Mahaney, ed., Quaternary stratigraphy of North America: Stroudsburg, Pa., Dowden, Hutchinson, and Ross, p. 119-132.

Yatsevitch, Yuri, 1969, Surficial geology of the Gloversville area: Rensselaer Polytechnic Inst. M.S. thesis, $73 \mathrm{p}$.

Zumberge, J. H., 1956, Late Pleistocene history of the Lake Michigan basin, in J. H. Zumberge, ed., The northwestern part of the Southern Peninsula of Michigan: Friends of the Pleistocene Guidebook Midwest Sec., 7th Ann. Mtg., Ann Arbor, Mich., 1956, p. 3-12.

1960, Correlation of Wisconsin drifts in Illinois, Indiana, Michigan, and Ohio: Geol. Soc. America Bull., v. 71, p. 1177-1188.

Zumberge, J. H., and Potzger, J. E., 1955, Pollen profiles, radiocarbon dating and geologic chronology of the Lake Michigan basin: Science, v. 121, p. 309-311.

1956, Late Wisconsin chronology of the Lake Michigan basin correlated with pollen studies: Geol. Soc. America Bull., v. 67, p. 271-288. 